\title{
Chemistry of the p-block Elements with Anionic Scorpionate Ligands
}

John Reglinski and Mark D. Spicer*

WestCHEM. Department of Pure \& Applied Chemistry, University of Strathclyde, 295 Cathedral Street, Glasgow, G1 1XL. UK.

\section{Abstract}

The chemistry of the $p$-block elements with both $\mathrm{N}$ - and S-donor anionic poly-heterocyclic borate ligands is reviewed, with an emphasis on the synthesis and structural types obtained.

\footnotetext{
* Corresponding Author
} 


\section{Introduction}

The pyrazole borate anions, first reported by Trofimenko in 1966 [1], have become immensely popular as ligands in the ensuing decades, and have become known as scorpionates in recognition of the resemblance of their coordination modes to a scorpion trapping its prey. The first generation of these anionic N-donor ligands (Chart 1), namely hydridotris(pyrazolyl)borate (Tp), tetrakis(pyrazolyl)borate (pzTp) and hydridotris(3,5dimethylpyrazolyl)borate $\left(\mathrm{Tp}^{*}\right)$ laid the basis for an extensive chemistry, with complexes now known for the majority of the metallic elements. The analogy with the cyclopentadienyl anion, i.e. as formally an anionic 6-electron donor, face capping ligand has certainly informed the development of its chemistry. It was quickly recognised that an enormous variety of substituted pyrazoles could be synthesised via reasonably straightforward procedures and a second generation of ligands based on pyrazoles substituted in the 3, 4, and 5 positions was forthcoming, with the majority appearing in the literature from the mid 1980s onwards. Substitution at boron, and use of alternative N-donor heterocycles has further expanded the family, while our group was instrumental in introducing heterocycles which give rise to ligands with a $\mathrm{S}_{3}$ donor set (Chart 1) [2, 3].

A distinct nomenclature has developed for these ligands [4] and is summarised in Chart 2. The abbreviations Bp (bispyrazolylborate) and Tp (trispyrazolylborate) are the basis for the system. The substituents on boron prefix this (i.e. R'Bp, R'Tp) but the prefix is omitted when $\mathrm{R}^{\prime}=\mathrm{H}$. The substituents on the pyrazole rings are denoted as superscripts following. The most common substituted ligand is hydridotris(3,5-dimethylpyrazolyl)borate and is abbreviated as $\mathrm{Tp}^{*}$ as a reference to pentamethylcyclopentadiene $\left(\mathrm{Cp}^{*}\right)$, but in general 3,5disubstituted are denoted by a single superscripted label, $\mathrm{Tp}^{\mathrm{R} 2}$. Other substitution patterns use additional numbers to indicate the position of substitution e.g. $\mathrm{Tp}^{4 \mathrm{R}}$ would be substituted in the 4-position. The S-donor scorpionates follow a similar pattern in their nomenclature, and although in the early literature a variety of abbreviations were used this has become more standard in recent years. Thus, the format $\mathrm{R}^{\prime} \mathrm{Bm}^{\mathrm{R}}$ and $\mathrm{R}^{\prime} \mathrm{Tm}^{\mathrm{R}}$ is used, with $\mathrm{R}$ ' referring to substitution at boron, and with $\mathrm{R}$ referring to substitution at the ring nitrogen. To date there are few examples of substitution at the 4 and 5 positions of the rings.

The S-donor methimazolylborates, while superficially similar to the pyrazole borates, also exhibit some marked differences in their behaviour. Since the S-donor atom is exo- to the heterocycle ring, the methimazolylborates form eight-membered chelates, whereas the 
pyrazole borates form six-membered chelates. Thus, while the $\mathrm{M}(\mathrm{Tp})$ fragment has local $\mathrm{C}_{3 \mathrm{v}}$ symmetry, the larger chelate rings in $\mathrm{M}(\mathrm{Tm})$ lead to a propeller-like $\mathrm{C}_{3}$ motif [2]. This geometry also results in the N-substituents being more distant from the metal centre than the 3-substituents in Tp complexes, resulting in a significantly lesser steric demand. The larger chelate rings also lead to greater conformational flexibility and one result of this is a wider range of coordination modes, and particularly the frequently observed $\kappa^{3}-\mathrm{S}, \mathrm{S}, \mathrm{H}$ coordination mode (Chart 3), in which the borohydride approaches the metal centre forming a probably somewhat electrostatic 3-centre-2-electron interaction, whose equivalent is rarely seen in $\mathrm{Tp}$ chemistry.

The chemistry of these ligands has been the subject of two books [5, 6] and many reviews [e.g. 7 - 12], but only four reviews specifically on their main group chemistry have appeared. Reger has reviewed their gallium and indium chemistry [13], Parkin has discussed s- and pblock alkyl, hydride and hydroxide derivatives supported by bulky pyrazolyl borates [14] and Janiak has twice reviewed the $\mathrm{Tl}^{\mathrm{I}}$ chemistry of these ligands $[15,16]$. In general, the chemistry of these ligands with the main group elements is very much less extensive than with the transition metals, lanthanides and actinides. Consequently in previous reviews, while main group compounds are mentioned, they are rarely prominent in their coverage. Our aim in this article is to provide a detailed overview of the current status of main group scorpionate chemistry. In order to do this, we have not sought to be entirely comprehensive in our coverage of the literature, but to paint a broad picture. In places this has meant delving back into the earlier literature in order not to leave large gaps. 


\section{Complexes of the $p$-Block Elements with N-donor Scorpionate Ligands.}

\subsection{Group 13.}

\subsubsection{Aluminium.}

The first reported aluminium scorpionate complex [17] was obtained by reaction of equimolar amounts of $\mathrm{KTp}$ with $\mathrm{AlCl}_{3}$ in $\mathrm{CH}_{2} \mathrm{Cl}_{2}$. In solution the presence of $\left[\mathrm{AlCl}_{4}\right]^{-}$was detected by ${ }^{27} \mathrm{Al}$ NMR (Sharp singlet at $\delta=98.5, \mathrm{w}_{1 / 2}=6 \mathrm{~Hz}$ ) while a second resonance $(\delta=$ $6.2, \mathrm{w}_{1 / 2}=12 \mathrm{~Hz}$ ) was attributed to an octahedral $\left[\mathrm{Al}(\mathrm{Tp})_{2}\right]^{+}$cation. Crystals suitable for $\mathrm{X}-$ ray diffraction studies could not be obtained.

The remaining aluminium scorpionate chemistry has utilised alkyl aluminium precursors. Parkin [18] reported the reaction of $\mathrm{AlMe}_{3}$ with $\mathrm{KTp}^{*}$ to yield [ $\mathrm{Al}\left(\mathrm{Tp}^{*}\right) \mathrm{Me}_{2}$ ] which has been spectroscopically characterised. ${ }^{1} \mathrm{H}$ NMR studies [19] show single environments for both the methyl and pyrazole protons from room temperature to $-90{ }^{\circ} \mathrm{C}$. This could be interpreted as either a highly fluxional 4-coordinate complex with a mobile $\kappa^{2}$-coordinated ligand or as a 5coordinate complex with a static $\kappa^{3}$-coordinated ligand. The related $\left[\mathrm{Al}\left(\mathrm{Tp}^{3-\mathrm{Bu}}\right) \mathrm{Me}_{2}\right]$ shows two sets of ${ }^{\mathrm{B} u p z}$ resonances in a 2:1 ratio, suggesting 4-coordination, with magnetisation transfer studies give $\Delta \mathrm{G}^{\ddagger}=17(2) \mathrm{Kcal} \mathrm{mol}^{-1}$ for the exchange process. It seems likely therefore that $\left[\mathrm{Al}\left(\mathrm{Tp}^{*}\right) \mathrm{Me}_{2}\right]$ is 5-coordinate. The difference in coordination numbers can be rationalised in terms of the cone angles, which for $\mathrm{Tp}^{3-\mathrm{tBu}}$ is somewhat larger than $\mathrm{Tp}^{*}$ [20]. $\left[\mathrm{Al}\left(\mathrm{Tp}^{3-\mathrm{tBu}}\right) \mathrm{Me}_{2}\right]$ is synthesised from the reaction of $\left[\mathrm{Tl}\left(\mathrm{Tp}^{3-\mathrm{tBu}}\right)\right]$ with either $\mathrm{AlMe}_{3}$ or $\mathrm{AlMe}_{2} \mathrm{Cl}$. In the former case, $\mathrm{Tl}$ metal is also formed, a result of the decomposition of the unstable metathesis product $\mathrm{TlMe}$. In the latter case $\mathrm{TlCl}$ is the by-product, indicating that metathesis of $\mathrm{Cl}$ is favoured over Me. Controlled hydrolysis of $\left[\mathrm{Al}\left(\mathrm{Tp}^{*}\right) \mathrm{Me}_{2}\right]$ results in the formation of what is believed to be the corresponding dihydroxo-species with the concomitant formation of methane. Interestingly, if $\mathrm{D}_{2} \mathrm{O}$ is used then a mixture of $\mathrm{CH}_{4}(13 \%)$ and $\mathrm{CH}_{3} \mathrm{D}(87 \%)$ are formed, and ${ }^{2} \mathrm{D}$ NMR indicates that $\mathrm{D}$ is incorporated at one of the methyl groups on the ligand. Finally, the $\mathrm{Bp}^{3-\mathrm{tBu}}$ complex, $\left[\mathrm{Al}\left(\mathrm{Bp}^{3-\mathrm{tBu}}\right) \mathrm{Me}_{2}\right]$, if heated to 100 ${ }^{\circ} \mathrm{C}$ undergoes isomerism in which one of the pyrazole groups is converted from $3-{ }^{\mathrm{t}} \mathrm{Bupz}$ to 5${ }^{t}$ Bupz (Scheme 1). Kinetic measurements indicate that the mechanism involves the decomplexation of one pyrazole followed by a 1,2-shift of boron from N1 to N2. Chisholm [21] has studied the related compound $\left[\mathrm{Al}\left(\mathrm{Tp}^{3-\mathrm{Hu}}\right) \mathrm{Et}_{2}\right]$. Crystallography reveals the expected 4-coordination at aluminium with a $\kappa^{2}$-ligand binding mode and a pendant pyrazole group. Furthermore, the isomerism noted above was also observed in this system and the structure of 
the isomerised product crystallographically determined. The structure shows that the $5-^{\mathrm{t}} \mathrm{Bu}-$ pyrazole coordinates to the aluminium in preference to a second 3 - $^{\mathrm{t}} \mathrm{Bu}$-pyrazole. The isomerisation has been studied by NMR spectroscopy in deuterated benzene, toluene and THF. The rate of isomerisation was significantly quicker in THF and the activation parameters obtained support a mechanism in which isomerisation takes place at a noncoordinated pyrazole via a 1,2-shift of boron.

A recent study [22] of the reaction of the aluminapyrazabole [ $\left.\mathrm{Al}\left(\mathrm{Et}_{2} \mathrm{Bpz}_{2}\right) \mathrm{Et}_{2}\right]$, first synthesised by Noth [23], with dry $\mathrm{O}_{2}$ at $-15^{\circ} \mathrm{C}$ showed the formation of an ethoxide bridged dimer which has been structurally characterised (Chart 4). The Al atoms are 5-coordinate in a square pyramidal geometry with $2 \mathrm{O}$ and $2 \mathrm{~N}$ atoms in the basal plane and an apical ethyl group. Evidence suggests an initial interaction of $\mathrm{O}_{2}$ with aluminium followed by insertion into the Al-C bond.

Reaction of $\left[\mathrm{Y}\left(\mathrm{AlMe}_{4}\right)_{3}\right]$ with $\mathrm{KTp}^{3-\mathrm{tBu}, 5-\mathrm{Me}}$ results in an unprecedented salt with an $\left[\mathrm{Al}\left(\mathrm{Tp}^{3-}\right.\right.$ $\left.\left.{ }_{\mathrm{tBu}, 5-\mathrm{Me}}\right) \mathrm{Me}\right]^{+}$cation and a $\left[\mathrm{Y}\left(\mathrm{AlMe}_{4}\right)\left(\mathrm{Me}_{2} \mathrm{Al}\left\{\mu-\mathrm{CH}_{2} \mathrm{AlMe}_{3}\right\}_{2}\right]^{-}\right.$anion [24]. The aluminium ion in the cation is 4-coordinate in a pseudo-tetrahedral arrangement (Figure 1), with the Tp ligand binding in a $\kappa^{3}$-mode.

In contrast to the species described above, which are all considerably prone to degradation when exposed to moisture or oxygen, the complex $\left[\mathrm{Al}\left(\mathrm{Tp}^{\mathrm{CF} 3}\right) \mathrm{Me}_{2}\right]$ can be handled in air without appreciable degradation [25]. The structure again shows a 4-coordinate tetrahedral structure (Figure 1) and the presence of weak Al....F interactions may well be the source of the stability of this compound.

\subsubsection{Gallium}

The first gallium Tp complex prepared was obtained from an equimolar mixture of KTp ${ }^{*}$ and $\mathrm{GaCl}_{3}$ in THF [17]. The ${ }^{71} \mathrm{Ga}$ NMR exhibited two sharp singlets of equal intensity at $\delta+2.8$ $\left(\mathrm{w}_{1 / 2}=60 \mathrm{~Hz}\right)$ and $\delta+239.2\left(\mathrm{w}_{1 / 2}=60 \mathrm{~Hz}\right)$, the latter attributable to the $\mathrm{GaCl}_{4}{ }^{-}$anion, and by inference, the former should arise from the $\left[\mathrm{Ga}\left(\mathrm{Tp}^{*}\right)_{2}\right]^{+}$cation. Crystallography confirmed this formulation, with the $\mathrm{Ga}^{3+}$ ion being coordinated in a close to regular octahedral geometry. Shortly after, Reger [26] reported reactions of $\mathrm{KBp}$ with freshly sublimed $\mathrm{GaCl}_{3}$ in THF, in ratios 2:1 and 3:1, which yielded neutral complexes $\left[\mathrm{Ga}(\mathrm{Bp})_{2} \mathrm{Cl}\right]$ and $\left[\mathrm{Ga}(\mathrm{Bp})_{3}\right]$ respectively. Both are stable in air in the solid state, though the former does slowly 
decompose in solution. The structure of $\left[\mathrm{Ga}(\mathrm{Bp})_{2} \mathrm{Cl}\right]$ has been determined [27] and reveals the $\mathrm{Ga}$ to be coordinated in a trigonal bipyramidal geometry (Figure 2). The axial Ga $-\mathrm{N}$ bond distances (2.065(2) $\AA$ ) are somewhat longer than their equatorial counterparts (1.964(2) $\AA$ ). The structure of $\left[\mathrm{Ga}(\mathrm{Bp})_{3}\right]$ is not known, but is assumed to be octahedral. Reaction of $\mathrm{KBp}$ with $\mathrm{GaCl}_{3}$ in a 1:1 ratio yields the salt $\left[\mathrm{Ga}\left(\mathrm{Bp}_{2}\right]\left[\mathrm{GaCl}_{4}\right][28]\right.$.

Further reactions of the Bp ligand with gallium(III) alkyls (Scheme 2) have also been reported [28]. Reaction of $\mathrm{CH}_{3} \mathrm{GaCl}_{2}$ with $\mathrm{KBp}$ in a 1:2 ratio gives $\left[\mathrm{Ga}(\mathrm{Bp})_{2} \mathrm{CH}_{3}\right]$, which is presumably analogous in structure to the corresponding chloride analogue (vide supra). An alternative synthesis of the methyl complex by methylation of the chloride using MeLi or $\mathrm{MeMgCl}$, did indeed yield the desired product, but always contaminated by other species. Reaction with only one equivalent of $\mathrm{KBp}$ gives rise to $\left[\mathrm{Ga}(\mathrm{Bp}) \mathrm{CH}_{3} \mathrm{Cl}\right]$ which molecular weight determination in benzene shows to be monomeric, implying a 4-coordinate structure. This complex can also be prepared by the exchange reaction between $\left[\mathrm{Ga}(\mathrm{Bp})_{2} \mathrm{Cl}\right]$ and $\left(\mathrm{CH}_{3}\right)_{2} \mathrm{GaCl}$. $\left[\mathrm{Ga}(\mathrm{Bp}) \mathrm{Me}_{2}\right]$ is formed as an oil either by treating [ $\left.\mathrm{Ga}(\mathrm{Bp}) \mathrm{MeCl}\right]$ with $\mathrm{MeLi}$, or by direct reaction of $\mathrm{GaMe}_{2} \mathrm{Cl}$ (synthesised in situ from $\mathrm{MeLi}$ and $\mathrm{GaCl}_{3}$ in the appropriate stoichiometry) with $\mathrm{KBp}$. Reaction of $\left[\mathrm{Ga}(\mathrm{Bp}) \mathrm{Me}_{2}\right]$ with excess $\mathrm{AcOH}$ results in elimination of a single equivalent of $\mathrm{CH}_{4}$ and the complex $[\mathrm{Ga}(\mathrm{Bp}) \mathrm{Me}(\mathrm{OAc})]$. A second acetate complex, $\left[\mathrm{Ga}(\mathrm{Bp})_{2}(\mathrm{OAc})\right]$, obtained from $\left[\mathrm{Ga}(\mathrm{Bp})_{2} \mathrm{Me}\right]$ and acetic acid, has been described and the structure determined by X-ray crystallography (Figure 2) reveals a pseudo-octahedral coordination geometry, comprising two $\kappa^{2}$-Bp ligands and a bidentate acetate.

An extension of these studies to Tp, $\mathrm{Tp}^{*}$ and $\mathrm{pzTp}$ ligands has been reported [29]. Reaction of all three ligands with $\mathrm{GaCl}_{3}$ leads to octahedral $\left[\mathrm{Ga}\left(\mathrm{R}^{\prime} \mathrm{Tp}^{\mathrm{R}}\right)_{2}\right]^{+}$cations, as previously reported [17]. With $\mathrm{MeGaCl}_{2}$ the product obtained depends on the stoichiometry of the reaction. Using a single equivalent of the ligand $\left(\mathrm{Tp}^{*}\right)$ gives rise to the tetrahedral $\left[\mathrm{Ga}\left(\mathrm{Tp}{ }^{*}\right) \mathrm{MeCl}\right]$ in which the ligand adopts a $\kappa^{2}$-bonding mode (Figure 3), while with the third pyrazole forming a weak interaction with gallium $(\mathrm{d}(\mathrm{Ga}-\mathrm{N})=2.897(7) \AA$, which is less than the sum of the van der Waals radii). Using two equivalents of the ligand yields $\left[\mathrm{Ga}\left(\mathrm{Tp}^{*}\right)_{2} \mathrm{Me}\right]$. This is a highly fluxional species in solution. The solid state structure of [Ga(pzTp) $\left.)_{2} \mathrm{Me}\right]$ (Figure 3) shows the complex to be octahedral, with one $\kappa^{3}$-pzTp, one $\kappa^{2}$-pzTp and a methyl bonded to gallium. It is assumed the $\mathrm{Tp}^{*}$ complex adopts an analogous structure. Finally, the three ligands also react with $\mathrm{Me}_{2} \mathrm{GaCl}$ to form complexes [ $\mathrm{Ga}\left(\mathrm{RTp}^{*}\right) \mathrm{Me}_{2}$ ], which are shown to be tetrahedral by X-ray crystallography (Figure 3), and in these compounds the non-coordinated pyrazoles are distant from the metal centre, unlike in in $\left[\mathrm{Ga}\left(\mathrm{Tp}^{*}\right) \mathrm{MeCl}\right]$. This possibly explains the slower 
rate of ligand exchange in this case. Thus, while in $\left[\mathrm{Ga}\left(\mathrm{Tp}^{*}\right) \mathrm{MeCl}\right]$ the pyrazole resonances in the ${ }^{1} \mathrm{H}$ NMR spectrum are not separated, even at $-90{ }^{\circ} \mathrm{C}$, in $\left[\mathrm{Ga}\left(\mathrm{Tp}^{*}\right) \mathrm{Me}_{2}\right]$ coalescence is observed, and a barrier of $13.7 \mathrm{kCal} \mathrm{mol}^{-1}$ to the exchange process has been determined. The majority of these complexes are stable to air and moisture in the solid state.

Reaction of $\left[\mathrm{Tl}\left(\mathrm{Tp}^{\mathrm{t}-\mathrm{Bu}, \mathrm{Me}}\right)\right]$ with $\left[\mathrm{HGaCl}_{2}\right]_{2}$ results in the formation of a gallium(III) Hydride cation in $\left[\mathrm{Ga}\left(\mathrm{Tp}^{\mathrm{t}-\mathrm{Bu}, \mathrm{Me}}\right) \mathrm{H}\right]\left[\mathrm{GaCl}_{4}\right]$ [30]. The crystal structure shows it to be tetrahedrally coordinated with three nitrogen donors and the hydride ligand (Figure 4). The Ga $-\mathrm{H}$ distance $(1.49(6) \AA)$ is comparable with the mean of $\mathrm{Ga}-\mathrm{H}$ distances in the Cambridge Crystallographic Database $(1.40 \AA)$ and with the distance obtained from DFT geometry optimisation of the hydride cation $(1.53 \AA)$. The $\mathrm{Ga}-\mathrm{N}$ distances are slightly shorter than in related gallium(III) $\mathrm{Tp}^{\mathrm{R}}$ complexes.

The first gallium(I) scorpionate complex was reported in 1996 by Parkin [31]. Reaction of the bulky $\mathrm{Tp}^{\mathrm{tBu}}$ ligand with "Gal" in pentane yielded $\left[\mathrm{Ga}\left(\mathrm{Tp}^{\mathrm{tBu}}\right)\right]$, while in benzene solution the species $\left[\left(\mathrm{Tp}^{\mathrm{tBu}}\right) \mathrm{Ga}-\mathrm{GaI}_{3}\right]$ was formed in low yield. [Ga( $\left.\left.\mathrm{Tp}^{\mathrm{tBu}}\right)\right]$ was the first discrete molecular gallium(I) complex to be crystallographically characterised. The $\mathrm{Ga}(\mathrm{I})-\mathrm{N}$ distances were $c a 0.17 \AA$ longer than corresponding $\mathrm{Ga}(\mathrm{III})-\mathrm{N}$ distances in gallium(III) complexes. The adduct $\left[\left(\mathrm{Tp}^{\mathrm{tBu}}\right) \mathrm{Ga}-\mathrm{GaI}_{3}\right]$ has also been crystallographically characterised. The $\mathrm{Ga}-\mathrm{N}$ bond lengths, at $c a 2.05 \AA$, are more akin to $\mathrm{Ga}(\mathrm{III})-\mathrm{N}$ distances, possibly as a result of electron donation to the $\mathrm{GaI}_{3}$ moiety, and the $\mathrm{Ga}-\mathrm{Ga}$ distance, at 2.506(3) $\AA$ is in line with covalent $\mathrm{Ga}$ - Ga distances, despite formally being a dative bond. Dias has reported formation of $\left[\mathrm{Ga}\left(\mathrm{Tp}^{(\mathrm{CF} 3) 2}\right)\right]$ synthesised by the reaction of $\left[\mathrm{Ag}\left(\mathrm{Tp}^{(\mathrm{CF} 3) 2}\right)\right.$ (toluene)] with GaI [32].

Parkin has shown that $\left[\mathrm{Ga}\left(\mathrm{Tp}^{\mathrm{tBu}}\right)\right]$ reacts with elemental sulphur to form a terminal sulfidospecies $\left[\mathrm{Ga}\left(\mathrm{Tp}^{\mathrm{tBu}}\right)(\mathrm{S})\right]$, (Figure 4) [33]. The $\mathrm{Ga}-\mathrm{S}$ bond distance (2.093(2) $\AA$ ) is markedly shorter than other $\mathrm{Ga}-\mathrm{S}$ distances (mean $2.33 \AA$ ), and this has been interpreted as evidence for $\mathrm{Ga}-\mathrm{S}$ multiple bond character. The $\mathrm{Ga}-\mathrm{S}$ moiety is very stable, with even $\mathrm{PMe}_{3}$ failing to abstract the sulphur atom.

Green has performed DFT calculations on these gallium(I) Tp complexes [34]. The geometry optimised structures were generally in good agreement with the crystallographic data, although the calculated $\mathrm{Ga}-\mathrm{N}$ distances were typically somewhat shorter than those determined experimentally. The HOMO in $[\mathrm{Ga}(\mathrm{Tp})]$ is the lone pair, which has $61 \% 4 s$ and $21 \% 4 p$ character, with only a small amount (18\%) of mixing with the Tp ligand. The Tp 
ligand interacts with the $4 s$ and $4 p_{\mathrm{x}, \mathrm{y}}$ orbitals. In the sulfido complex $[\mathrm{Ga}(\mathrm{Tp})(\mathrm{S})]$ the calculations show a $\sigma$-bond between the HOMO (lone pair) on Ga and the $3 s$ and $3 p_{z}$ orbitals of sulphur. Furthermore, a $\pi$-interaction between sulphur $p_{\mathrm{x}}$ and $\mathrm{p}_{\mathrm{y}}$ orbitals and an orbital of suitable symmetry on Ga is observed. The bond is best described as a semi-polar covalent bond, in which the resonance structure $\mathrm{Ga}^{+}-\mathrm{S}^{-}$is dominant. In the compound [(Tp)Ga- $\left.\mathrm{GaI}_{3}\right]$ the main metal-metal bonding interaction is between the HOMO (lone pair) on [Ga(Tp)] and the LUMO of $\mathrm{GaI}_{3}$, along with weaker ancillary interactions. Again, the bond is polarised, with the Mulliken charges of +0.79 on the Ga atom coordinated by Tp and -0.15 on the Ga atom in the $\mathrm{GaI}_{3}$ moiety, suggesting an ionic component in the Ga-Ga bond. There is no evidence for multiple bonding in these species.

Parkin has reported a series of compounds based on the [Ga(Tp)] unit which have Ga-Ga bonds [35]. Reaction of $\mathrm{KTp}^{*}$ with "GaI" yields not only the compound [(Tp")Ga-GaI 3 , but two additional compounds, $\left[\left(\mathrm{Tp}^{*}\right) \mathrm{Ga}\left(\mathrm{Ga}_{2} \mathrm{I}_{4}\right) \mathrm{Ga}\left(\mathrm{Tp}^{*}\right)\right] \quad$ (Figure 5) and $\left[\left(\mathrm{Tp}^{*}\right) \mathrm{Ga}\left(\mathrm{Ga}_{2} \mathrm{I}_{4}\right)\left(\mathrm{pz}^{\mathrm{Me} 2} \mathrm{H}\right)\right]$ which contain concatenated chains of four and three gallium atoms respectively. Both may be thought of as double adducts of $\mathrm{Ga}_{2} \mathrm{I}_{4}$ formed by disproportionation of "GaI". In the chloride analogues, formed by reaction of $\left[\mathrm{Tl}\left(\mathrm{Tp}^{*}\right)\right]$ and $\mathrm{Ga}\left(\mathrm{GaCl}_{4}\right)_{2}$, the expected compound [ $\left.\left(\mathrm{Tp}^{*}\right) \mathrm{Ga}-\mathrm{GaCl}_{3}\right]$ was the major product, with small quantities of $\left[\mathrm{Ga}\left(\mathrm{Tp}^{*}\right)_{2}\right]\left[\mathrm{GaCl}_{4}\right]$ and the dinuclear compound $\left[\left(\mathrm{Tp}^{*}\right) \mathrm{Ga}-\mathrm{Ga}\left(\mathrm{Tp}^{*}\right)\right]$ also being formed (Figure 5). Addition to $\mathrm{B}\left(\mathrm{C}_{6} \mathrm{~F}_{5}\right)_{3}$ to these reaction mixtures leads to formation of the $\left[\left(\mathrm{Tp}^{*}\right) \mathrm{Ga}-\mathrm{B}\left(\mathrm{C}_{6} \mathrm{~F}_{5}\right)_{3}\right]$ adduct.

Finally, the donor ability of the $\left[\left(\mathrm{Tp}^{*}\right) \mathrm{Ga}\right]$ fragment has been exploited in the formation of [(Tp $\left.\left.{ }^{*}\right) \mathrm{Ga}-\mathrm{Fe}(\mathrm{CO})_{4}\right]$ (Chart 5) by the reaction of $\left[\left(\mathrm{Tp}^{*}\right) \mathrm{GaMeCl}\right]$ with $\mathrm{Na}_{2}\left[\mathrm{Fe}(\mathrm{CO})_{4}\right]$ [36]. The favoured bonding description is a two-electron dative bond, and the Lewis basicity of the $\left[\left(\mathrm{Tp}^{*}\right)\right]$ fragment, based on the $\mathrm{CO}$ stretching frequencies of the $\mathrm{Fe}(\mathrm{CO})_{4}$ fragment, is greater than either phosphines or pyridines in related complexes.

\subsubsection{Indium.}

Reaction of $\mathrm{InCl}_{3}$ with $\mathrm{KTp}^{*}$ in THF, followed by recrystallization from $\mathrm{MeCN}$ solution resulted in the formation of $\left[\operatorname{In}\left(\mathrm{Tp}^{*}\right)\left(\mathrm{NCMe} \mathrm{Cl}_{2}\right]\right.$ [17]. The indium is octahedrally coordinated with a facially capping $\kappa^{3}$-coordinated $\mathrm{Tp}^{*}$ ligand, two chloride ions and an acetonitrile molecule in the coordination sphere. The "sandwich" compound $\left[\operatorname{In}\left(\operatorname{Tp}^{*}\right)_{2}\right] \mathrm{I}$ was 
prepared at low temperature from InI and $\mathrm{KTp}^{*}$ in a 1:2 ratio in toluene [37]. The crystal structure confirmed a regular $\mathrm{N}_{6}$ coordination sphere around indium.

The compound $\left[\operatorname{In}(\mathrm{Bp})_{3}\right]$ has been prepared by the reaction of $\mathrm{KBp}$ and $\operatorname{In}\left(\mathrm{NO}_{3}\right)_{3}$ in water [38]. Mass spectrometry and ${ }^{1} \mathrm{H}$ and ${ }^{13} \mathrm{C}$ NMR data are consistent with a complex of this composition, while the ${ }^{115} \mathrm{In} \mathrm{NMR}$, with a linewidth of $4300 \mathrm{~Hz}$ (compared to $200 \mathrm{~Hz}$ for $\left.\left[\operatorname{In}\left(\mathrm{OH}_{2}\right)_{6}\right]^{3+}\right)$ is consistent with a pseudo-octahedral (distorted) coordination geometry. This geometric interpretation is confirmed by X-ray crystallography (Figure 6), with $\mathrm{In}-\mathrm{N}$ bonds in the range 2.219(5) - 2.268(5) $\AA$ and the $\mathrm{N}-\mathrm{In}-\mathrm{N}$ angles lying between 85.5(2) and $99.9(2)^{\circ}$.

Reger has extensively studied the reactions of pyrazolylborate ligands with indium. The species obtained are in many cases closely analogous to those of gallium (vide supra). In a study of the reactions of $\mathrm{KBp}$ with $\mathrm{InCl}_{3}, \mathrm{MeInCl}_{2}$ and $\mathrm{Me}_{2} \mathrm{InCl}$ a variety of monomeric complexes were obtained [39]. A 1:1 ratio of $\mathrm{InCl}_{3}$ and $\mathrm{KBp}$ yields $\left[\operatorname{In}(\mathrm{Bp}) \mathrm{Cl}_{2}\right]$, which in contrast to the majority of indium scorpionate complexes is extremely susceptible to decomposition. Its limited solubility hints at an oligomeric nature. Reactions utilising ligand to metal ratios of $2: 1$ and $3: 1$ yield $\left[\operatorname{In}(\mathrm{Bp})_{2} \mathrm{Cl}\right]$ and $\left[\operatorname{In}(\mathrm{Bp})_{3}\right]$ respectively, the former being trigonal bipyramidal like the $\mathrm{Ga}$ analogue, while the latter has been crystallographically characterised as discussed previously [38]. The analogous $\left[\operatorname{In}(\mathrm{Bp})_{2} \mathrm{Me}\right]$ is prepared from $\mathrm{MeInCl}_{2}$ with two equivalents of ligand [39]. Reaction of $\mathrm{MeInCl}_{2}$ with only one equivalent of ligand gives $[\operatorname{In}(\mathrm{Bp}) \mathrm{MeCl}]$, which is monomeric in solution, but which in the solid state forms weakly associated dimers (Figure 7). [ $\left.\operatorname{In}(\mathrm{Bp}) \mathrm{Me}_{2}\right]$ is prepared from $\mathrm{KBp}$ and $\mathrm{Me}_{2} \mathrm{InCl}$, and crystallography discloses a tetrahedral, monomeric structure, with a large $\mathrm{C}-\mathrm{In}-\mathrm{C}$ angle of $141.1(1)^{\circ}$.

Reaction of $\mathrm{MeInCl}_{2}, \mathrm{KBp}$ and $\mathrm{CH}_{3} \mathrm{CO}_{2} \mathrm{H}$ in a 1:1:1 Ratio gives a compound formulated as $[\mathrm{In}(\mathrm{Bp}) \mathrm{Me}(\mathrm{OAc})]$ which, from solution molecular weight measurements, is dimeric. Doubling the amount of KBp in the reaction mixture results in methane elimination leading to a second compound, $\left[\operatorname{In}(\mathrm{Bp})_{2}(\mathrm{OAc})\right]$. A similar study using $\mathrm{Tp}, \mathrm{Tp}^{*}$ and $\mathrm{pzTp}$ as the ligands [40] confirms that, as in the analogous gallium chemistry, either 4- or 6-coordination is preferred. Reaction of $\mathrm{InCl}_{3}$ with three equivalents of $\mathrm{K}(\mathrm{pzTp})$ gives the complex $\left[\operatorname{In}(\mathrm{pzTp})_{3}\right]$ in which it is thought that the the three ligands are present in a $\kappa^{2}$ - bonding mode. The fluxional behaviour observed via ${ }^{1} \mathrm{H}$ NMR spectroscopy is consistent with this structure. When reacted in a 2:1 ratio, the same reagents give $\left[\operatorname{In}(\mathrm{pzTp})_{2} \mathrm{Cl}\right]$, believed to be a species 
with one $\kappa^{3}$-pzTp, one $\kappa^{2}$-pzTp and a chloride ligand completing an octahedral coordination sphere. The metathesis reaction of this species with MeLi at low temperature, or reaction of $\mathrm{MeInCl}_{2}$ with two equivalents of pzTp, give the methyl analogue, [In(pzTp $)_{2} \mathrm{Me}$, which has been characterised crystallographically, confirming the proposed structure. Finally, reaction of $\mathrm{InCl}_{3}$ with $\mathrm{KTp}$ in THF in a 1:1 ratio results in formation of the presumed octahedral $\left[\operatorname{In}(\mathrm{Tp})(\mathrm{THF}) \mathrm{Cl}_{2}\right]$.

A series of mixed ligand complexes have been formed [41] by reaction of $\left[\operatorname{In}\left(\mathrm{Tp}^{*}\right)(\mathrm{THF}) \mathrm{Cl}_{2}\right]$ with the disodium salt of maleonitriledithiolate at elevated temperatures to form

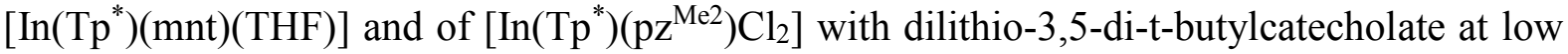
$\left(-78^{\circ} \mathrm{C}\right)$ temperature to form $\left[\operatorname{In}\left(\mathrm{Tp}^{*}\right)(\mathrm{cat})\left(\mathrm{Hpz}^{\mathrm{Me}}\right)\right]$. The latter has been crystallographically characterised and is an octahedral complex. Various indium $\mathrm{Tp}^{*}$ complexes containing a second pyrazole borate ligand have also been prepared by a similar methodology.

As noted above, $\left[\operatorname{In}\left(\mathrm{Tp}^{*}\right)_{2}\right] \mathrm{Cl}$ can be isolated, but it was observed that although the crystal structure showed it to be the "sandwich" complex, other data was inconsistent with this formulation [42]. It was thought that hydrolysis might be the reason for this observation, and thus $\left[\operatorname{In}\left(\mathrm{Tp}^{*}\right)_{2}\right] \mathrm{I}$ was refluxed in wet acetonitrile. The resulting complex was a dimeric species $\left[\left\{\operatorname{In}\left(\mathrm{Tp}^{*}\right)\right\}_{2}\left(\mu-\mathrm{pz}^{\mathrm{Me} 2}\right)_{2}(\mu-\mathrm{OH})\right] \mathrm{I}$ bridged by two $\mathrm{pz}^{\mathrm{Me} 2}$ ligands (presumably derived from hydrolysis of the $\mathrm{Tp}^{*}$ ligand) and a hydroxide ion (Chart 6), in which each indium is in an octahedral $\mathrm{N}_{5} \mathrm{O}$ coordination environment. Reaction of $\mathrm{InI}_{3}$ with $\mathrm{KTp}^{*}$ also results in partial hydrolysis of the $\mathrm{Tp}^{*}$ ligand and formation of the monomeric octahedral complex $\left[\mathrm{In}\left(\mathrm{Tp}^{*}\right)\left(\mathrm{pz}^{\mathrm{Me} 2}\right) \mathrm{I}_{2}\right]$. Reaction of $\mathrm{InCl}_{3}$ and $\mathrm{KTp}^{*}$ in a $1: 1$ ratio followed by addition of $\mathrm{K}_{2} \mathrm{~S}_{5}$ yields a polysulfide complex $\left[\operatorname{In}\left(\mathrm{Tp}^{*}\right)\left(\mathrm{pz}^{\mathrm{Me} 2}\right)\left(\mathrm{S}_{4}\right)\right]$ [43]. The ${ }^{1} \mathrm{H}$ NMR spectrum is broad at room temperature, but on cooling sharpens to give a spectrum consistent with the above formulation. The structure has a distorted octahedral geometry with the $\mathrm{InS}_{4}$ ring adopting a half-chair conformation. A "mixed sandwich" complex with the ligand $\mathrm{CpCo}\left\{\mathrm{P}(\mathrm{O})(\mathrm{R})_{2}\right\}_{3}\left(\mathrm{~L}_{\mathrm{R}}\right.$ $\mathrm{R}=\mathrm{OMe}, \mathrm{Chart} 7$ ) and $\mathrm{Tp}$ have been prepared [44] by reaction of $\mathrm{InCl}_{3}$ and the two ligands in a 1:1:1 ratio. It is formulated as $\left[\operatorname{In}\left(\mathrm{LOMe}_{\mathrm{O}}\right)(\mathrm{Tp})\right]\left[\mathrm{InCl}_{4}\right]$, which is readily converted to the $\mathrm{PF}_{6}{ }^{-}$salt by reaction with $\mathrm{NH}_{4} \mathrm{PF}_{6}$. $2 \mathrm{D}-\mathrm{NMR}$ studies confirm that the two ligands are attached to the same metal. Reaction of $\mathrm{AgLOMe}$ and $\mathrm{TlL} \mathrm{L}_{\mathrm{Et}}$ with $\left[\operatorname{In}\left(\mathrm{Tp}^{*}\right) \mathrm{Cl}_{2}(\mathrm{NCMe})\right]$ lead to complexes $\left[\operatorname{In}\left(\mathrm{L}_{\mathrm{OMe}}\right)\left(\mathrm{Tp}^{*}\right)\right]\left[\mathrm{AgCl}_{2}\right]$ and $\left[\operatorname{In}\left(\mathrm{L}_{\mathrm{Et}}\right)\left(\mathrm{Tp}^{*}\right)\right] \mathrm{Cl}$ respectively [45]. The crystal structure confirms this to be the first example of an indium complex with both $\mathrm{O}_{3}$ and $\mathrm{N}_{3}$ tripodal ligands coordinated. 
Indium(I) complexes are less abundant than those of indium(III). In the presence of $\mathrm{Tp}^{*}$ indium(I) iodide was observed to disproportionate to indium(0) and indium(III) [37], although latterly, $\left[\operatorname{In}\left(\mathrm{Tp}^{*}\right)\right]$ has been prepared from $\mathrm{K}\left(\mathrm{Tp}^{*}\right)$ and $\mathrm{InCl}[30]$. With the bulkier ligand $\mathrm{Tp}^{3 \mathrm{Ph}}$, InI reacts at $-30{ }^{\circ} \mathrm{C}$ in $\mathrm{THF}$ to form the $1: 1$ adduct $\operatorname{InTp}{ }^{3 \mathrm{Ph}}$ [46]. The X-ray crystal structure (Figure 8) confirms a monomeric complex with a trigonal pyramidal arrangement, with $\mathrm{In}-\mathrm{N}$ bond distances ca $0.2 \AA$ longer than in corresponding indium(III) complexes, and the $\mathrm{N}-\mathrm{In}-\mathrm{N}$ angles are substantially less than $90^{\circ}\left(78.2(2)^{\circ}\right)$ in contrast to the indium(III) complexes which have $\mathrm{N}-\mathrm{In}-\mathrm{N}$ angles close to $90^{\circ}$. The related complexes of $\mathrm{Tp}^{3 \mathrm{BBu}}$ and $\mathrm{Tp}^{3-\mathrm{tBu}, 5 \mathrm{Me}}$ have been prepared by reaction of $\left[\mathrm{Tl}\left(\mathrm{Tp}^{\mathrm{R}}\right)\right]$ with $\mathrm{InCl}$ $[47,30]$, and the complexes of the $\mathrm{Tp}^{(\mathrm{CF} 3) 2}$ ligand have been prepared by metathesis of $\left[\mathrm{Ag}\left(\mathrm{Tp}^{(\mathrm{CF} 3) 2}\right)(\mathrm{THF})\right]$ with $\mathrm{InCl}$ in $\mathrm{THF}$ at $-78^{\circ} \mathrm{C}[48,32]$. The structure of the latter is similar, but the $\mathrm{In}-\mathrm{N}$ bond distances are elongated when compared to the $\mathrm{Ph}$ and ${ }^{\mathrm{t}} \mathrm{Bu}$ substituted analogues (2.600(3) and 2.533(5) $\AA$ vs $2.43 \AA$ (av)) and this has been ascribed to the electron withdrawing effect of the $\mathrm{CF}_{3}$ groups lessening the basicity of the $\mathrm{N}$-donor atoms. The indium(I) compound $\left[\operatorname{In}\left(\mathrm{Tp}^{\mathrm{tBu} 2}\right)\right]$ is also readily oxidised, by $\mathrm{I}_{2}$ to give $\left[\operatorname{In}\left(\mathrm{Tp}^{\mathrm{tBu} 2}\right) \mathrm{I}_{2}\right]$ and by $\mathrm{S}_{8}$ to give $\left[\operatorname{In}\left(\mathrm{Tp}^{\mathrm{tBu} 2}\right)\left(\eta^{2}-\mathrm{S}_{4}\right)\right]$, both 5-coordinate indium(III) complexes [49]. The latter reacts with $\mathrm{PR}_{3}(\mathrm{R}=\mathrm{Me}, \mathrm{Et})$ to yield the indium(I) complex $\left[\operatorname{In}\left(\mathrm{Tp}^{\mathrm{tBu} 2}\right)\right]$ and also is the source of the terminal sufido ligand in $\left[\mathrm{Ga}\left(\mathrm{Tp}^{\mathrm{tBu} 2}\right)(=\mathrm{S})\right]$ vide supra [33]. Reaction of $\left[\operatorname{In}\left(\mathrm{Tp}^{\mathrm{tBu} 2}\right)\right]$ with elemental selenium, by contrast, results in the formation of a terminal selenido complex, $\left[\operatorname{In}\left(\operatorname{Tp}^{\mathrm{tBu} 2}\right)(=\mathrm{Se})\right][50]$ (Figure 9), the bulky ligand preventing the formation of oligomers. The In - Se bond distance $(2.376(1) \AA)$ is much shorter than other In - Se distances (ca $2.65 \AA$ ), consistent with multiple bond character. Reaction of $\left[\operatorname{In}\left(\mathrm{Tp}^{*}\right) \mathrm{Cl}_{2}(\mathrm{THF})\right]$ with the carbonyl anion in $\mathrm{Na}_{2} \mathrm{Fe}(\mathrm{CO})_{4}$ in $\mathrm{THF}$ yields $\left[\operatorname{In}\left(\mathrm{Tp}^{*}\right) \mathrm{Fe}(\mathrm{CO})_{4}\right.$ ] [51]. X-ray crystallography reveals a trigonal bipyramidal iron centre, with the $\operatorname{In}\left(\mathrm{Tp}^{*}\right)$ ligand in an axial position. The analogous reaction with $\mathrm{Na}_{2} \mathrm{~W}(\mathrm{CO})_{5}$ results in formation of $\left[\operatorname{In}\left(\mathrm{Tp}^{*}\right) \mathrm{W}(\mathrm{CO})_{5}\right]$. In both complexes it is believed that the carbonylate anions reduce the indium(III) precursor to an indium(I) species, which is able to act as a Lewis base toward the transition metal fragment.

\subsubsection{Thallium}

The pyrazolylborate chemistry of thallium is based exclusively on thallium(I) and has been reviewed until 1997 [15,160]. This review will only consider developments thereafter. Approximately 90 complexes of formula $\left[\mathrm{Tl}\left(\mathrm{Tp}^{\mathrm{R}}\right)\right]$ have been crystallographically 
characterised and this popularity arises from a number of factors. The thallium(I) complexes are stable and less prone to solvent inclusion than the alkali metal salts, resulting in greater ease of purification, and thus thallium salts are often used as a means to obtaining pure samples of new scorpionate ligands. Additionally, they are more soluble in organic solvents, serving to extend their utility. Their primary use is as metathetical ligand transfer agents. In the reaction of pyrazolyl borates with transition metal halides the discrepancy of the hard Ndonor ligand and soft thallium(I) ion, coupled with the formation of thermodynamically stable thallium(I) halides, constitutes a strong driving force for the reaction. The simple separation of the thallium halide by filtration also aids experimental simplicity.

Thallium(I) $\mathrm{Tp}^{\mathrm{R}}$ complexes all form a single structural motif, in which the metal is found in a trigonal pyramidal coordination environment. The parent complex [Tl(Tp)] has been structurally characterised $[52,53]$ showing an approximately (though not crystallographic) $\mathrm{C}_{3 \mathrm{v}}$ symmetric trigonal pyramidal arrangement (Figure 10). Substitution of the group in the 3position only marginally changes the metrical parameters and has been reported for $3 \mathrm{R}=$ cyclobutyl and cyclopentyl [54], diphenylmethyl [55], mesityl [56], and most recently, adamantyl [57]. If the groups in the 3-position have potential donor atoms then species with secondary donor interactions are observed. When $3 \mathrm{R}=$ carboxypyrrolidine [58], the three $\mathrm{Tl}$ - N distances average $2.709 \AA$, while the three Tl...O distances average $3.004 \AA$. For 2(pinene[4,5]pyridyl) substituents a $C_{3}$ symmetric tripodal ligand is generated [59] (Figure 11), in which the $\mathrm{Tl}-\mathrm{N}$ distances are 2.719(3) and 2.721(3) $\AA$ and the Tl... N distances arising from interaction with the 2-pyridyl groups are 3.101(3) and 3.131(3) $\AA$ in the two crystallographically unique molecules. In the $\mathrm{C}(\mathrm{Me})_{2} \mathrm{CH}_{2} \mathrm{OMe}$ substituted $\mathrm{Tp}$ ligand $[60,61]$ three pyrazole nitrogen atoms coordinate to the thallium(I) ion, but only two of the ether oxygen atoms interact with the thallium ion, the third being remote from the metal at a distance of 6.258(2) $\AA$ (Figure 11). Interestingly, the ${ }^{1} \mathrm{H}$ NMR spectrum shows only one environment for the pendant groups, implying rapid exchange of the ether groups. The phosphine oxide pendant ligand, tetrakis(3-(2-diphenylphosphinylphenyl)pyrazolyl)borate [62] forms a thallium(I) complex in which only two of the pyrazole nitrogen atoms coordinate to the metal, along with a single phosphine oxide. The inability of a third pyrazole to coordinate to the metal is attributed to the steric hindrance induced by the fourth substituent at boron. The corresponding phosphine, tris(3-(2diphenylphosphinophenyl)pyrazolyl)borate [63], forms the more usual tridentate complex with three $\mathrm{Tl}-\mathrm{N}$ bonds and weak interactions $(3.2122(9)-3.2488(9) \AA)$ with the three 
phosphorus atoms which lie co-planar to the metal ion (Figure 11). Despite the long $\mathrm{Tl}-\mathrm{P}$ distances, the phosphine interactions are persistent in solution as evidenced by the ${ }^{31} \mathrm{P}-$ ${ }^{205 / 207} \mathrm{Tl}$ coupling in the ${ }^{31} \mathrm{P}$ NMR spectrum. Thallium complexes of two Tp ligands containing amide groups $\left(\mathrm{RNC}(\mathrm{O}), \mathrm{R}=\mathrm{Ph},{ }^{\mathrm{t}} \mathrm{Bu}\right)$ in the 3 position and methyl substitutents in the 5-position have also been reported [64]. In the case where $\mathrm{R}=$ phenyl a symmetric species is obtained in which the three amide oxygen atoms are directed towards the thallium centre, whereas, when $\mathrm{R}=\mathrm{t}$-butyl, only one is directed to the thallium coordinated by the three pyrazole rings, but one also bridges to a second thallium ion forming a loosely associated dimer.

A number of bis-pyrazolylborates with the potentially ligating groups 2-pyridyl ( $\left.\mathrm{Bp}^{3(2-\mathrm{py})}\right)$ [65], 6-(2,2'-bipyridyl) $\left(\mathrm{Bp}^{3(2,2-b i p y)}\right)$, [66] and 2-pyrazinyl $\left(\mathrm{Bp}^{3(2-\mathrm{pyz})}\right)$ [67] substituted in the 3position of the pyrazole rings have been prepared. The 2-pyridyl substituted species gives a monomeric complex with a " $2+2$ " coordination, in which the pyrazole nitrogen atoms are strongly coordinated to thallium while the two pyridyl nitrogen atoms are more remote. The four donor atoms form the basal plane of a square pyramid and the lone pair is directed towards the apex. The individual units stack along the Tl...Tl axis. In the bipyridyl substituted complex the metal is in a " $3+2$ " geometry, in which two pyrazole and one pyridyl nitrogen coordinate strongly, with two further pyridyl nitrogen atoms weakly interacting with the metal centre. The pyrazine substituted complex again exhibits a " $2+2$ " geometry as observed in the 2-pyridyl analogue above, with stacking along the T1...Tl axis. The external pyrazine nitrogen atoms are not involved in interactions with neighbouring metal ions. When groups which are not capable of chelating to the central metal ion are used (e.g. 3-pyridyl and 4- pyridyl) then the formation of coordination polymers is observed [68, 69]. The structure of $\left[\mathrm{Tl}\left(\mathrm{Bp}^{4 \mathrm{py}}\right)\right]$ shows it to be a coordination polymer in which the two pyrazoles are bonded to one thallium atom and the three coordinate pyramidal coordination environment is completed by two 4-pyridyl nitrogen atoms from adjacent monomers $(\mathrm{d}(\mathrm{Tl}-\mathrm{N})=2.687(7) \AA)$. The result is a 1D helical chain. The 3-pyridyl analogue forms a similar arrangement (Figure 12). These compounds dissolve in strong donor solvents such as dmso and dmf presumably with dissociation of the polymer. The corresponding $\mathrm{Tp}^{4 \mathrm{py}}$ ligand complexes as a symmetrical tridentate ligand to $\mathrm{Tl}(\mathrm{I})$ and in this case the assembly into a 1-D helical polymer is by a much weaker secondary interaction with a single 4-pyridyl nitrogen from an adjacent complex $(\mathrm{d}(\mathrm{Tl}-\mathrm{N})=2.978(8) \AA)$ (Figure 12). The 3-pyridyl analogue $\left[\mathrm{Tl}\left(\mathrm{Tp}^{3 \mathrm{py}}\right)\right]$ has a similar monomer unit, but now has weak interactions with the pyridyl nitrogen atoms from 
three adjacent units, assisted by $\pi$-stacking, resulting in a 2-D sheet structure (Figure 13). With the tetra-substituted borate ligands, $3 \mathrm{pyTp}^{3 \mathrm{py}}$ and $4 \mathrm{pyTp}^{4 \mathrm{py}}$ a more distorted thallium(I) core is observed, with two of the pyrazoles bonding strongly and one weakly. In the $4 p y T p^{4 p y}$ complex the monomers are assembled into 2D chiral sheets via interactions with adjacent 4pyridyl groups. In the 3-pyridyl analogue two pyrazole nitrogen atoms are strongly bonded to thallium while the third ring in the vicinity of the metal adopts a face-on bonding mode. The stronger secondary interactions with adjacent 3-pyridyl groups results in a ladder structure, and these ladders are then assembled into a 2D sheets by weaker 3-pyridyl-thallium(I) interactions.

Thallium(I) complexes of 3-phenyl-4-cyanopyrazolyl and 3-t-butyl-4-cyanopyrazolyl borates show the familiar trigonal pyramidal structure, but while the phenyl substituted derivative shows some some association into coordination polymers via three cyano-nitrogen atoms interacting with the thallium ion [70], the t-butyl substituted derivative does not exhibit this interaction [71]. This has been rationalised on the basis of the greater steric bulk of the t-butyl group. The thallium(I) complexes of the related bis pyrazolylborates, $\mathrm{Bp}{ }^{\mathrm{Ph}, 4 \mathrm{CN}}$ and $\mathrm{Bp} \mathrm{p}^{\mathrm{tBu}, 4 \mathrm{CN}}$ have also been structurally characterised [72]. The phenyl derivative has a coordination sphere consisting of the two pyrazole nitrogen atoms and an interaction with the one of the $\mathrm{H}-$ atoms bound to boron. There are also weak interactions with the pyrazole nitrogen atoms on a neighbouring metal and a weak CN...Tl interaction. The t-butyl substituted complex, by contrast, bonds strongly to the two pyrazole nitrogen atoms and the borohydride from one ligand, two cyano-groups from two further ligands and the borohydride of a third neighbouring ligand. In each of these complexes the $\mathrm{Tl}-\mathrm{N}$ bonded distances are markedly longer than in many other pyrazolyl borate derivatives, and this is thought to arise from the electron withdrawing effect of the cyano groups.

The thallium(I) complexes of a series of pyrazolyl borates containing fluorinated substituents have also been reported. The complex with $\mathrm{MeTp}^{3 \mathrm{CF} 3}$ has the standard trigonal pyramidal structure and shows ${ }^{203 / 205} \mathrm{Tl}-{ }^{19} \mathrm{~F}$ Coupling in the ${ }^{19} \mathrm{~F}$ NMR spectrum [73]. The complex with the perfluorinated ligand tris(3-trifluoromethyl-4,5,6,7-tetrafluoroindazolyl)borate (Chart 8) again has a trigonal pyramidal structure, but also shows additional Tl...F contacts in the range $2.98-3.22 \AA$. There are also significant interactions of fluorine atoms with the $\pi$ aromatic system [74]. With the $\mathrm{Tp}^{\mathrm{C} 3 \mathrm{~F} 7,5 \mathrm{Me}}$ ligand a similar situation pertains, and there ${ }^{19} \mathrm{~F}$ NMR spectrum shows coupling of each of the three resonances with the thallium ion. This is ascribed to through space coupling, and the X-ray structure shows close contacts between the 
metal and the fluorinated substituent $[75,76]$. Complexes with $\mathrm{C}_{2} \mathrm{~F}_{5}, \mathrm{C}_{4} \mathrm{~F}_{9}$ and $\mathrm{C}_{6} \mathrm{~F}_{13}$ substitutents are also reported, but not structurally characterised. Tris(3-Aryl-4,5,6,7tetrafluoroindazolyl)borate (aryl $=\mathrm{Ph}, 3,5-\mathrm{Me}_{2} \mathrm{C}_{6} \mathrm{H}_{3}, 3,5-\left(\mathrm{F}_{3} \mathrm{C}_{2} \mathrm{C}_{6} \mathrm{H}_{3}, \mathrm{C}_{6} \mathrm{~F}_{5}\right.$; Chart 8) complexes of $\mathrm{Tl}$ are unusually formed by reaction the parent indazole and $\mathrm{TlBH}_{4}$ [77]. (This method has previously been reported for a series of pyrazolyl and indazolyl borate thallium complexes [78]). All form the expected structural motif. The pentafluorophenyl substituted ligand, however, undergoes a rearrangement such that one of the indazolyl groups has migrated such that it is bonded through the nitrogen in the 2-position, rather than the 1position (Figure 15). The related bis(indazolyl)borate is also prepared from the indazole and $\mathrm{TlBH}_{4}$ and also undergoes this rearrangement, in this case with both indazoles bonded through the 2-position. Bis and tris pyrazolyl borates derived from 3,5bis(trifluoromethyl)pyrazole form complexes with thallium(I) which have been crystallographically characterised [79]. The $\mathrm{Tp}^{(\mathrm{CF} 3) 2}$ complex adopts the expected trigonal pyramidal motif, with weak interactions with fluorine atoms from neighbouring molecules. The $\mathrm{Bp}^{(\mathrm{CF} 3) 2}$ ligand forms a more complex structure, in which the ligand is bonded via two pyrazole nitrogen atoms and the coordination sphere is completed by interactions with the two borohydrides from one neighbouring complex and two fluorine atoms from a second neighbouring complex, resulting in a zig-zag chain structure.

Thallium(I) complexes of a number of pyrazolyl borates substituted at boron, $\mathrm{R}^{\prime} \mathrm{Tp}^{\mathrm{R}}$ have also been reported. Ligands that are 3-substituted at pyrazole, with methyl at boron, MeTp ${ }^{3 R}$ $\left(3 \mathrm{R}=\mathrm{Me}\right.$ [80], ${ }^{\mathrm{t}} \mathrm{Bu}$ [81], Mesityl [81], $\mathrm{Ph}$ [82]) yield the expected trigonal pyramidal structures. However, introduction of substituents in the 5-position (e.g. in tris(3,5-dimethyl pyrazolyl)borate [80]) yields a structure in which two of the pyrazoles are coordinated to thallium, but the third, due to the steric hindrance between the 5-methyl and the B-Me groups, is unable to do so. The coordination sphere is thus completed by donation from a pendant pyrazole from an adjacent molecule leading to polymeric arrays. A similar situation pertains when bulkier groups are appended at boron. Thus, in the thallium(I) complexes with $\mathrm{RTp}\left(\mathrm{R}=\mathrm{Ph}\right.$ [83], cymantrene and methylcymantrene [84], 4- $\mathrm{BrC}_{6} \mathrm{H}_{4}$ [85]) the ligand is only able to act in a bidentate fashion due to the steric bulk of the group on the bridgehead atom. In $\left[\mathrm{Tl}\left(\mathrm{PhTp}^{3 \mathrm{BBu}}\right)\right]$ the third "arm" is rotated through approximately $90^{\circ}$, resulting in an interaction with the pyrazole $\pi$-system rather than with the nitrogen lone pair. The structure is strictly monomeric in nature [83]. In the cymantrene derivatives the subtle effect of the addition of a methyl group to the $\mathrm{Cp}$ ring of the $\mathrm{Mn}(\mathrm{Cp})(\mathrm{CO})_{3}$ fragment results in different 
arrangements [84]. Thus the complex of the parent is polymeric in nature (Figure 16), the pendant pyrazole arm bonding to an adjacent thallium centre to form a 1-D polymer. In the methyl cymantrene species, however, a cyclic tetramer is obtained (Figure16), the remote methyl group causing a small shift in the angle of the pyrazole ring which enables the formation of the cyclic species. Interestingly, in solution the NMR spectra are consistent with a monomeric species, suggesting that the oligomeric nature is only extant in the solid state. The 4-bromophenyltris(pyrazolyl)borate ligand again binds in a dihapto- fashion to the thallium(I) ion In this case, the third pyrazole nitrogen does not interact with a neighbouring complex, but instead a van der Waals interaction with the bromine on the aromatic group occurs.

The effect of placing substitutents in the 4-position has also been studied. Placing a t-butyl group in this position, with a 3-p-tolyl group $\left(\mathrm{Tp}^{3 \text { tol,4tBu}}\right)$ does not result in a significant change in behaviour with respect to the coordination chemistry with thallium [86]. The effect of adding a 4-phenyl group to 3-benzyl substituted ligands was found to be minimal in terms of the thallium chemistry, but did result in differences with transition metals [87].

The effect of multiple substitutions has also been studied. Formation of thallium complexes with hydrotris(3-phenyl-4,5-dibromopyrazolyl)borate and the p-tolyl and p-chlorophenyl analogues all results in a rearrangement such that the three aryl groups occupy the 5-position. On the other hand the hydrotris(3- $p$-chlorophenyl-4-bromopyrazolyl)borate and hydrotris(3phenyl-4-bromo-5-methylpyrazolyl)borate both form complexes without undergoing rearrangement. It is presumed that steric effects are the cause of this phenomenon [88].

Tp-related ligand hydrotris(indazoyl)borate [53, 89] forms a thallium(I) complex as expected, with the additional aromatic rings facilitating extensive $\pi$-stacking.

A series of bispyrazoylborate ligands have also been reacted with thallium. The parent dihydrobis(pyrazolyl)borate has the expected bidentate coordination, but additionally there is a weak interaction with the borohydride, and a relatively short $\mathrm{Tl} \ldots . \mathrm{Tl}$ interaction at 3.7001(6) $\AA$, less than twice the van der Waals radius of thallium (3.92 $\AA$ ) [90]. 


\subsection{Group 14}

\subsubsection{Silicon}

Reaction of $\mathrm{SiCl}_{4}$ with $\mathrm{KpzTp}$ results in formation of a compound formulated as [Si(pzTp)Cl ${ }_{3}$. The ${ }^{1} \mathrm{H}$ NMR spectrum shows two pyrazole environments in a 3:1 ratio, suggesting an octahedral complex. This is supported by a ${ }^{29} \mathrm{Si}$ NMR shift of $-196.6 \mathrm{ppm}$. However, reactions with $\mathrm{Bp}$ and $\mathrm{Et}_{2} \mathrm{Bp}$ with $\mathrm{SiCl}_{4}, \mathrm{MeSiCl}_{3}$ and $\mathrm{Me}_{2} \mathrm{SiCl}_{2}$ yielded inseparable mixtures with evidence for cleavage of pyrazole from the ligand and formation of pyrazaboles [22]. In general the silicon complexes are unstable and not easily purified.

\subsubsection{Germanium}

Reaction of $\mathrm{GeCl}_{4}$ with $\mathrm{KpzTp}$ results in formation of [ $\left.\mathrm{Ge}(\mathrm{pzTp}) \mathrm{Cl}_{3}\right]$ which was identified by NMR spectroscopy and mass spectrometry, but which could not be separated from an impurity. Reaction of $\mathrm{Et}_{2} \mathrm{GeCl}_{2}$ with 2 equivalents of KpzTp led to the initial formation of $\left[\mathrm{Ge}(\mathrm{pzTp})_{2} \mathrm{Et}_{2}\right]$ as identified by NMR spectroscopy, but it decomposed rapidly both in solution and in the solid state. Reaction of $\mathrm{Et}_{2} \mathrm{GeCl}_{2}$ with $\mathrm{Et}_{2} \mathrm{Bpz}_{2}$ yields only the pyrazabole $\mathrm{Et}_{2} \mathrm{~B}(\mu-\mathrm{pz})_{2} \mathrm{BEt}_{2}$ and a hydrolytically unstable complex $\mathrm{Et}_{2} \mathrm{Ge}(\mathrm{pz})_{2}$ [22]. Addition of $\mathrm{KTp}^{*}$ to a slight excess of $\left[\mathrm{GeCl}_{2}\right.$ (dioxane)] yields the compound formulated as [ $\left.\mathrm{Ge}\left(\mathrm{Tp}^{*}\right)\right] \mathrm{Cl}$ [91]. Exchange of the chloride for iodide and $\mathrm{PF}_{6}{ }^{-}$was achieved and the crystal structure of the iodide salt showed a 3-coordinate trigonal pyramidal structure, with the iodide significantly separated from the cation. Latterly the chloride salt was crystallised and shown to have a 4coordinate structure [92]. The geometry is best described as distorted trigonal bipyramidal, with the chloride and one pyrazole in the axial positions and two pyrazoles in an equatorial site. The final site is presumably occupied by the germanium lone pair. The $\mathrm{Ge}-\mathrm{Cl}$ distance is approximately $0.25 \AA$ longer than other $\mathrm{Ge}-\mathrm{Cl}$ distances. This compound was converted to the corresponding azide by reaction with $\mathrm{NaN}_{3}$ and has an analogous structure. The azide is linear, and has a $\mathrm{N}-\mathrm{N}-\mathrm{Ge}$ angle of $136.8(3)^{\circ}$, somewhat larger than in other main group azides (Figure 17). It is suggested that there is considerable ionic character in the Ge $-\mathrm{X}$ bonds in these species. 


\subsubsection{Tin}

The first reported tin Tp complex was prepared by reaction of $\mathrm{Me}_{3} \mathrm{SnCl}$ with $\mathrm{KTp}$, yielding the six-coordinate [ $\left.\mathrm{Sn}(\mathrm{Tp}) \mathrm{Me}_{3}\right]$ [93]. The colourless complex is air sensitive, decomposing completely in $\mathrm{CH}_{2} \mathrm{Cl}_{2}$ at room temperature in five hours. The crystal structure confirms the octahedral arrangement and shows narrow $\mathrm{N}-\mathrm{Sn}-\mathrm{N}$ angles $\left(74.8(1)^{\circ}\right)$ and wide $\mathrm{C}-\mathrm{Sn}-\mathrm{C}$ angles $\left(105.2(1)^{\circ}\right)$. Soon after a second study resulted in the isolation of $\left[\mathrm{Sn}(\mathrm{Tp}) \mathrm{Cl}_{3-\mathrm{x}} \mathrm{Me}_{\mathrm{x}}\right](\mathrm{x}$ $=0,1,2)$ and $\left[\mathrm{Sn}(\mathrm{Tp}) \mathrm{I}_{3}\right]$ [94]. A number of series of related compounds have been prepared: $\left[\operatorname{Sn}(\mathrm{Tp}) \mathrm{R}_{2} \mathrm{X}\right]\left(\mathrm{X}=\mathrm{Cl}, \mathrm{R}=\mathrm{Me}, \mathrm{Et},{ }^{\mathrm{n}} \mathrm{Bu}, \mathrm{Ph} ; \mathrm{X}=\mathrm{Br}, \mathrm{R}=\mathrm{Me},{ }^{\mathrm{n}} \mathrm{Bu}\right) ;\left[\operatorname{Sn}(\mathrm{Tp}) \mathrm{RCl}_{2}\right](\mathrm{R}=\mathrm{Me}$, $\left.{ }^{\mathrm{n}} \mathrm{Bu}, \mathrm{Ph}\right)[95]$; the tetrakispyrazolyborate analogues $\left[\mathrm{Sn}(\mathrm{pzTp}) \mathrm{R}_{2} \mathrm{X}\right]\left(\mathrm{X}=\mathrm{Cl}, \mathrm{R}=\mathrm{Me}, \mathrm{Et},{ }^{\mathrm{n}} \mathrm{Bu}\right.$, $\mathrm{Ph} ; \mathrm{X}=\mathrm{Br}, \mathrm{R}=\mathrm{Me}, \mathrm{Et}) ;\left[\mathrm{Sn}(\mathrm{pzTp}) \mathrm{RCl}_{2}\right]\left(\mathrm{R}=\mathrm{Me},{ }^{\mathrm{n}} \mathrm{Bu}, \mathrm{Ph}\right) ;$ and $\left[\operatorname{Sn}(\mathrm{pzTp}) \mathrm{X}_{3}\right](\mathrm{X}=\mathrm{Cl}, \mathrm{Br})$ [96]; and the 3,5-dimethylpyrazolyl analogues $\left[\operatorname{Sn}\left(\mathrm{Tp}^{*}\right) \mathrm{R}_{2} \mathrm{X}\right]\left(\mathrm{X}=\mathrm{Cl}, \mathrm{R}=\mathrm{Me}, \mathrm{Et},{ }^{\mathrm{n}} \mathrm{Bu}, \mathrm{Ph} ; \mathrm{X}\right.$ $=\mathrm{Br}, \mathrm{R}=\mathrm{Me}, \mathrm{Et}) ;\left[\mathrm{Sn}\left(\mathrm{Tp}^{*}\right) \mathrm{RCl}_{2}\right]\left(\mathrm{R}=\mathrm{Me},{ }^{\mathrm{n}} \mathrm{Bu}, \mathrm{Ph}\right)$ and $\left[\mathrm{Sn}\left(\mathrm{Tp}^{*}\right) \mathrm{X}_{3}\right](\mathrm{X}=\mathrm{Cl}, \mathrm{Br})$ [97]. All are shown to be non-fluxional from their ${ }^{1} \mathrm{H}$ and ${ }^{13} \mathrm{C}$ NMR spectra, and from their ${ }^{119} \mathrm{Sn}$ NMR spectra are deduced to be octahedral with the exception of the monohalogeno compounds, which are thought to have lower coordination numbers in solution. The Crystal structure of $\left[\mathrm{Sn}(\mathrm{pzTp}) \mathrm{Me}_{2} \mathrm{Cl}\right]$ was determined [21], and the structures of [ $\left.\mathrm{Sn}(\mathrm{Tp}) \mathrm{Ph}_{2} \mathrm{Cl}\right],\left[\mathrm{Sn}\left(\mathrm{Tp}^{*}\right) \mathrm{Ph}_{2} \mathrm{Cl}\right]$ and $\left[\mathrm{Sn}(\mathrm{Tp}) \mathrm{Cl}_{3}\right]$ were also subsequently obtained [98], and the solid state structures in each case show octahedral geometries. Mossbauer spectra show a greater s-electron density at the metal nucleus as the structures adopt a more regular octahedral geometry, implying a decrease in s-character in the metal ligand bonds [98]. Reaction of the ester tin compound $\mathrm{MeO}_{2} \mathrm{CCH}_{2} \mathrm{CH}_{2} \mathrm{SnCl}_{3}$ with $\mathrm{KTp}$ yields the complex [ $\mathrm{Sn}(\mathrm{Tp})\left(\mathrm{CH}_{2} \mathrm{CH}_{2} \mathrm{CO}_{2} \mathrm{Me}\right) \mathrm{Cl}_{2}$ ], which readily undergoes metathesis with $\mathrm{KSCN}$ to give the corresponding [Sn(Tp) $\left.\left(\mathrm{CH}_{2} \mathrm{CH}_{2} \mathrm{CO}_{2} \mathrm{Me}\right)(\mathrm{NCS})_{2}\right]$ complex, both of which have been crystallographically characterised showing the expected octahedral complexes [99]. An analogous compound with itaconic ester $\left(\mathrm{CH}_{2} \mathrm{CH}\left(\mathrm{CO}_{2} \mathrm{Me}\right)\left(\mathrm{CH}_{2} \mathrm{CO}_{2} \mathrm{Me}\right)\right)$ has also been described [100]. Reaction of $\mathrm{Me}_{2} \mathrm{SnCl}_{2}$ with two equivalents of $\mathrm{KTp}$ or KpzTp leads to the species [ $\left.\mathrm{Sn}\left(\mathrm{R}^{\prime} \mathrm{Tp}\right)_{2} \mathrm{Me}_{2}\right](\mathrm{R}=$ $\mathrm{H}, \mathrm{pz}$ ). In solution, NMR spectroscopy reveals a highly labile species, exhibiting only one pyrazolyl environment, while cooling results in the freezing of four different species, although these could not be identified. The compounds are both thermally sensitive and highly moisture sensitive [101]. $\left[\mathrm{Sn}\left(\mathrm{Tp}^{*}\right)\left({ }^{\mathrm{n}} \mathrm{Bu}\right)_{2} \mathrm{Cl}\right]$ has been used as a $\mathrm{Tp}^{*}$ ligand transfer agent in the formation of $\left[\mathrm{M}(\mathrm{Tp}) \mathrm{Cl}_{3}\right]$ from $\mathrm{MCl}_{4}$ species $(\mathrm{M}=\mathrm{Zr}, \mathrm{Nb}, \mathrm{Ta})$ [102].

A handful of Bp complexes with tin(IV) are also known. Nicholson prepared the compounds $\left[\mathrm{Sn}(\mathrm{Bp}) \mathrm{Cl}_{3-\mathrm{x}} \mathrm{Me}_{\mathrm{x}}\right](\mathrm{x}=0,1,2,3)$ and the crystal structure of $\left[\mathrm{Sn}(\mathrm{Bp}) \mathrm{Me}_{2} \mathrm{Cl}\right]$ shows these 
species to be five coordinate with a somewhat distorted trigonal bipyramidal coordination sphere [94]. The corresponding $\left[\mathrm{Sn}\left(\mathrm{Ph}_{2} \mathrm{Bp}\right) \mathrm{Me}_{2} \mathrm{Cl}\right]$ has also been crystallographically characterised [21]. Complexes of general formula $\left[\operatorname{Sn}\left(\mathrm{R}_{2} \mathrm{Bp}\right) \mathrm{R}_{2}{ }_{2}\right]\left(\mathrm{R}=\mathrm{Et}, \mathrm{R}^{\prime}=\mathrm{Et},{ }^{\mathrm{n}} \mathrm{Bu} ; \mathrm{R}=\right.$ $\mathrm{H}, \mathrm{Ph}, \mathrm{R}^{\prime}=\mathrm{Me}$ ) have also been isolated, but they are highly unstable toward heat and hydrolysis. By addition of water to a solution of $\left[\mathrm{Sn}\left(\mathrm{Et}_{2} \mathrm{Bp}\right) \mathrm{Me}_{2}\right]$ a dimeric hydrolysis product was isolated in which one pyrazole $\mathrm{N}-\mathrm{B}$ bond has been cleaved with concomitant $\mathrm{B}-\mathrm{O}$ bond formation. The resulting oxygen bridges between the two tin centres (Figure 18) [101].

Tin(II) chemistry is less extensive than that of the higher oxidation state. Cowley reported the reaction of $\mathrm{SnCl}_{2}$ with one or two equivalents of $\mathrm{KTp}^{*}$ to yield $\left[\mathrm{Sn}\left(\mathrm{Tp}{ }^{*}\right) \mathrm{Cl}\right]$ and $\left[\mathrm{Sn}\left(\mathrm{Tp}^{*}\right)_{2}\right]$ respectively [103]. Both have been characterised crystallographically and both reveal the structural impact of the non-bonded electron pair. The former is trigonal bipyramidal, with four donor atoms and the lone pair occupying an axial position. The latter is octahedral, again with one coordination site occupied by the lone pair. NMR, in both cases was consistent with considerable fluxionality in the solution state. The mass spectrum showed a very weak parent ion, while the base peak corresponded to the $\left[\operatorname{Sn}\left(\operatorname{Tp}^{*}\right)\right]^{+}$ion, confirming the lability of these species. A number of analogous species, utilising alternative ligands ( $\mathrm{Tp}, \mathrm{Tp}{ }^{3 \mathrm{Me}}, \mathrm{pzTp}, \mathrm{Bp}$, $\mathrm{Ph}_{2} \mathrm{Bp}$ ) have been prepared and their ${ }^{119} \mathrm{Sn}$ NMR spectra utilised to differentiate between the varying coordination numbers [104]. The structure of $\left[\operatorname{Sn}(\mathrm{Tp})_{2}\right]$ has also been determined crystallographically and reveals a similar structure to that of the $\mathrm{Tp}^{*}$ analogue [105] (figure 19). Additional studies by Reger have added a series of bispyrazolylborate compounds, $\left[\mathrm{Sn}\left\{\mathrm{B}(\mathrm{pz})_{4-\mathrm{n}}\right\}_{\mathrm{m}} \mathrm{Cl}_{2-\mathrm{m}}\right](\mathrm{n}=0,1,2 ; \mathrm{m}=1,2)$ which have been isolated and characterised [106]. The Bp complex $\left[\mathrm{Sn}(\mathrm{Bp})_{2}\right]$ was the subject of a low resolution X-ray structure determination which showed the coordination sphere to be trigonal bipyramidal with a lone pair in one axial site. The corresponding $[\mathrm{Sn}(\mathrm{Bp}) \mathrm{Cl}]$ is tetrahedral with a lone pair filling one vertex. The molecules are weakly associated through long $\mathrm{Sn} \ldots \mathrm{Cl}$ contacts. Comparison of solid state and solution ${ }^{119} \mathrm{Sn}$ NMR data shows that with the exception of $\left[\operatorname{Sn}(\mathrm{Bp})_{2}\right]$ the structures in the solid state are representative of those in solution [107]. Curiously, the structure of [Sn(pzTp $)_{2}$ ] reveals both ligands to be coordinated in a $\kappa^{2}$-mode, rather than the $\kappa^{3}, \kappa^{2}$-mode seen in the parent Tp complex [106]. 


\subsubsection{Lead}

As far as can be ascertained, there are no complexes of scorpionate ligands with lead(IV), presumably a result of the oxidising nature of this ion. However, a number of lead(II) complexes are known. The compounds $\left[\mathrm{Pb}\left(\mathrm{R}^{\prime} \mathrm{Tp}^{\mathrm{R}}\right)_{2}\right]$ are readily prepared from $\mathrm{PbCl}_{2}$ and the potassium salt of the ligand in aqueous solution [107]. An interesting structural progression is observed (Figure 20). With the pzTp ligand both ligands adopt a $\kappa^{2}$-bonding mode which results in a distorted trigonal bipyramid with one axial site occupied by the lone pair of electrons, very similar to the related tin compound [106]. With the parent Tp ligand a facecapped octahedral arrangement is observed, whereby the six pyrazole nitrogen atoms coordinate to the lead(II) ion and the lone pair occupies a vertex, capping a face defined by three pyrazole nitrogen atoms. Finally, with $\mathrm{Tp}^{*}$ a much more regular octahedral arrangement is seen, implying a stereochemically inactive lone pair. Interestingly, the bond distances in the latter two complexes are very similar, whereas it might be expected that the stereochemically inactive lone pair might cause a bond length extension. It would appear that the pzTp ligand is sterically too bulky around the boron atom to allow it to coordinate in the normal $\kappa^{3}$-mode. The Tp ligand adopts a structure driven by the metal lone pair, while the structure of the $\mathrm{Tp}^{*}$ complex is driven by the bulk of the ligand 3,5-substituents to form a regular octahedral species. A series of mixed tripod complexes with the $\mathrm{O}_{3}$ - donor ligand $\left[(\mathrm{Cp}) \mathrm{Co}\left(\mathrm{P}(\mathrm{O})(\mathrm{OEt})_{2}\right)_{3}\right]$ and the scorpionate ligands $\mathrm{Bp}, \mathrm{Tp}, \mathrm{Tp}^{*}$ and pzTp have been prepared and characterised, but could not be crystallised [108]. In an effort to synthesise complexes of $(\mathrm{O}) \mathrm{P}\left(3,5-\mathrm{Me}_{2} \mathrm{pz}\right)_{3}$ by mixing with $\mathrm{Pb}\left(\mathrm{NO}_{3}\right)_{2}$ and $\mathrm{KTp}^{*}$ the unexpected complex $\left[\mathrm{Pb}\left(\mathrm{Tp}^{*}\right)\left(\mathrm{ONO}_{2}\right)\right]$ has been obtained. It has been crystallographically characterised showing a trigonal bipyramidal structure with the lone pair occupying an equatorial position. In an attempt to prepare $\left[\mathrm{Pb}\left(\mathrm{P}(\mathrm{O})\left(3,5-\mathrm{Me}_{2} \mathrm{pz}\right)\right)\left(\mathrm{Tp}^{*}\right)\right]$ ligand decomposition has been observed (probably the result of $\mathrm{HCl}$ in the phosphine oxide ligand) to yield $\left[\mathrm{Pb}\left(\mathrm{Tp}^{*}\right)\left(\mathrm{Hpz}^{3,5 \mathrm{Me}}\right)_{3}\right] \mathrm{Cl}$. The $\mathrm{Tp}^{*}$ ligand is $\kappa^{3}$-coordinated and adopts a conformation identical to that in $\left[\mathrm{Pb}\left(\mathrm{Tp}^{*}\right)_{2}\right]$, the three pyrazoles occupy the second face and the chloride ion is hydrogen bonded to the three pyrazole hydrogen atoms. The lone pair is stereochemically active, pointing through the face defined by the three pyrazole ligands and towards the chloride ion (Figure21). Reaction of lead chloride, KSCN and KTp in THF yields a stable white solid with empirical formula [Pb(Tp)(NCS)] [109] The crystal structure reveals a complicated infinite 2D array in which $[\mathrm{Pb}(\mathrm{Tp})]^{+}$groups sandwich a layer of $\mathrm{SCN}^{-}$groups. The related $\mathrm{Tp}^{*}$ complex is a dimer (Figure 21) which is spanned by two different bridging NCS ligands. One bridges through a 
single $\mathrm{S}$ atom, while the other bridges via both $\mathrm{N}$ and $\mathrm{S}$. The free nitrogen of the first bridging SCN links to neighbouring lead atoms to form a polymeric chain.

When a tris(1,2,4-triazolyl)borate ligand (Chart 9) is reacted with $\mathrm{Pb}\left(\mathrm{NO}_{3}\right)_{2}$ in water the product which initially crystallises has the formula $\left[\mathrm{Pb}\left\{\mathrm{HB}(\text { Triazolyl })_{3}\right\}\left(\mathrm{OH}_{2}\right)\left(\mathrm{ONO}_{2}\right)\right][110]$. Crystallography shows this to be a seven coordinate species with the triazolylborate coordinating in a $\kappa^{3}$-mode, a water and monodentate nitrate ligand. The remaining sites are filled by interaction with the 4-nitrogen atoms of ligands in two neighbouring complexes, resulting in a two-dimensional coordination polymer. There is a void in the coordination geometry consistent with a hemidirected lone pair (Figure 22). If left in the mother liquor, the rhombic crystals of $\left[\mathrm{Pb}\left\{\mathrm{HB}(\text { Triazolyl })_{3}\right\}\left(\mathrm{OH}_{2}\right)\left(\mathrm{ONO}_{2}\right)\right]$ transform over a number of days into needle shaped crystals. These are shown to have the formula $\left[\mathrm{Pb}\left\{\mathrm{HB}(\text { Triazolyl })_{3}\right\}_{2}\left(\mathrm{OH}_{2}\right)_{2}\right]$ which has a bent $\mathrm{PbL}_{2}$ structure (Figure 22), reminiscent of lanthanide Tp complexes [e.g. 110]. The lone pair is thought to be holodirected in this case.

\subsection{Group 15}

\subsubsection{Phosphorus}

Reaction of $\left(\mathrm{o}-\mathrm{C}_{6} \mathrm{H}_{4} \mathrm{O}_{2}\right) \mathrm{PCl}$ with $\mathrm{KpzTp}$ results only in the formation of the pyrazabole $(\mathrm{pz})_{2} \mathrm{~B}(\mu-\mathrm{pz})_{2} \mathrm{~B}(\mathrm{pz})_{2}$, with no evidence of Tp complex formation [22].

\subsubsection{Arsenic}

Reaction of $\mathrm{Me}_{2} \mathrm{AsBr}$ with KpzTp results in the formation of a compound formulated as [As(pzTp)Me $\mathrm{Me}_{2}$. The ${ }^{1} \mathrm{H}$ NMR shows this species to be fluxional, but even at $-90{ }^{\circ} \mathrm{C}$ the peaks are not fully resolved and so it has not proven possible to imply a structure for this species [22].

\subsubsection{Antimony}

There are no reported complexes of Tp ligands with antimony. 


\subsubsection{Bismuth}

A single bismuth complex of $\mathrm{Tp}$ has been prepared by reaction of $\mathrm{BiCl}_{3}$ with $\mathrm{NaTp}$ in acetone at $0{ }^{\circ} \mathrm{C}$. Extensive decomposition occurs, deposting metallic bismuth, but a white crystalline solid can be obtained in moderate yield from the cold solution [112]. The compound obtained, [Bi(Tp) $2(\mathrm{pzH}) \mathrm{Cl}]$ is eight coordinate (Figure 23$)$, with two Tp ligands in a "bent" arrangement with a chloride to balance the charge and a protonated pyrazole, arising from the observed decomposition of the Tp ligand. The structure is reminiscent of some lanthanide complexes with these ligands [111] 


\section{Complexes of the p-Block Elements with S-donor Scorpionate Ligands.}

\subsection{Group 13.}

\subsubsection{Aluminium}

To date, only two examples of soft scorpionate complexes of aluminium are known [113], namely $\left[\mathrm{Al}\left(\mathrm{Bm}^{\mathrm{R}}\right) \mathrm{Cl}_{2}\right]\left(\mathrm{R}=\mathrm{Me},{ }^{\mathrm{t}} \mathrm{Bu}\right)$, synthesised by treatment of $\mathrm{AlCl}_{3}$ with $\mathrm{LiBm}^{\mathrm{R}}$. The $\mathrm{X}$ ray structures reveal a tetrahedrally coordinated metal centre and the eight-membered chelate ring adopts a chair-like conformation, directing the borohydride groups away from the metal centre, rather than allowing a B - H ...M interaction as observed in other related compounds.

\subsubsection{Gallium}

Simple mononuclear gallium(III) complexes are obtained by reaction of $\mathrm{MTm}^{\mathrm{R}}(\mathrm{M}=\mathrm{Tl}, \mathrm{R}=$ ${ }^{\mathrm{t}} \mathrm{Bu} ; \mathrm{M}=\mathrm{Li}, \mathrm{R}=$ adamantyl) with $\mathrm{GaX}_{3}(\mathrm{X}=\mathrm{Cl}, \mathrm{I})[114,115]$. The iodide, when reacted in a 1:1 molar ratio yields $\left[\mathrm{Ga}\left(\mathrm{Tm}^{\mathrm{R}}\right) \mathrm{I}\right] \mathrm{I}$ in which the gallium is pseudo-tetrahedrally coordinated in a $\mathrm{S}_{3} \mathrm{I}$ donor set. With $\mathrm{GaCl}_{3}$ in a 1:2 ratio, the related $\left[\mathrm{Ga}\left(\mathrm{Tm}^{\mathrm{R}}\right) \mathrm{Cl}\right]\left[\mathrm{GaCl}_{4}\right]$ is the product. A complex with a ligand to gallium ratio of $2: 1,\left[\mathrm{Ga}\left(\mathrm{Tm}^{\mathrm{R}}\right)_{2} \mathrm{I}\right]$ is accessed by reaction of $\left[\mathrm{Tl}\left(\mathrm{Tm}^{\mathrm{tBu}}\right)\right]$ with $\mathrm{GaI}_{3}$ in a 2:1 ratio. NMR and subsequent crystallographic analysis (Figure 24) reveals the $\mathrm{Tm}^{\mathrm{tBu}}$ ligand to be $\kappa^{2}$-coordinated, resulting in a 5-coordinate species.

Reactions of "Gal" with $\left[\mathrm{M}\left(\mathrm{Tm}^{\mathrm{tBu}}\right)\right](\mathrm{M}=\mathrm{K}, \mathrm{Tl})$ do not result in formation of the expected gallium(I) complex $\left[\mathrm{Ga}\left(\mathrm{Tm}^{\mathrm{tBu}}\right)\right]$. Rather, depending on conditions, a series of compounds containing $\mathrm{Ga}-\mathrm{Ga}$ bonds are produced. With $\mathrm{KTm}^{\mathrm{tBu}}$ in benzene at room temperature the dinuclear dication $\left[\left(\mathrm{Tm}^{\mathrm{tBu}}\right) \mathrm{Ga}-\mathrm{Ga}\left(\mathrm{Tm}^{\mathrm{tBu}}\right)\right]^{2+}$ is obtained, while in acetonitrile at $-35{ }^{\circ} \mathrm{C}$, the trinuclear $\left[\left(\mathrm{Tm}^{\mathrm{tBu}}\right) \mathrm{Ga}\left(\mathrm{GaI}_{2}\right) \mathrm{Ga}\left(\mathrm{Tm}^{\mathrm{tBu}}\right)\right] \mathrm{I}$ results. Using $\left[\mathrm{Tl}\left(\mathrm{Tm}^{\mathrm{tBu}}\right)\right]$ in acetonitrile at $-35^{\circ} \mathrm{C}$ and then warming to room temperature yields $\left[\left(\mathrm{Tm}^{\mathrm{tBu}}\right) \mathrm{Ga}-\mathrm{GaI}_{3}\right]$, while without warming the remarkable ion pair, $\left[\left(\mathrm{Tm}^{\mathrm{tBu}}\right) \mathrm{Ga}-\mathrm{Ga}\left(\mathrm{Tm}^{\mathrm{tBu}}\right)\right]^{2+}\left[\left(\kappa^{1}, \kappa^{2}-\mathrm{Tm}^{\mathrm{tBu}}\right) \mathrm{GaI}_{2} \mathrm{GaI}_{2} \mathrm{GaI}^{-}{ }_{2}\right.$ containing both dinuclear and trinuclear ions is produced. The trinuclear ion contains a unique bridging mode for the Tm ion in which two sulphur atoms coordinate to one gallium atom and the third sulphur coordinates to the most distant gallium. These products may be rationalised in terms of i) formation of $\left[\mathrm{Ga}\left(\mathrm{Tm}^{\mathrm{tBu}}\right)\right]$, and ii) the disproportionation of " $\mathrm{GaI}$ " to $\mathrm{Ga}^{0}$ and $\mathrm{GaI}_{3}$, followed by a series of subsequent reactions. The molecular structures (Figure 25) as determined by X-ray diffraction reveal $\mathrm{Ga}-\mathrm{Ga}$ distances in the range 2.406(3) to 2.4586(5) 
$\AA$, comparable to twice the covalent radius of gallium $(2.44-2.48 \AA)$ and commensurate with other $\mathrm{Ga}-\mathrm{Ga}$ single bond distances.

Reaction of GaI with $\mathrm{NaBm}^{\mathrm{tBu}}$ results in formation of the monomeric gallium (III) complex $\left[\mathrm{Ga}\left(\mathrm{Bm}^{\mathrm{tBu}}\right) \mathrm{I}_{2}\right]$ and the formally gallium(II) dimer, $\left[\left(\mathrm{Bm}^{\mathrm{tBu}}\right)(\mathrm{GaI})(\mathrm{GaI})\left(\mathrm{Bm}^{\mathrm{tBu}}\right)\right][113]$. The analogous reaction with $\mathrm{LiTm}^{\mathrm{Me}}$ also yields the dimeric species. In both the ligand adopts a chair-like configuration, but the structures differ in the orientation of the $\mathrm{Bm}^{\mathrm{R}}$ ligand. In the complex with the less bulky $\mathrm{Bm}^{\mathrm{Me}}$ the ligand is directed over the $\mathrm{Ga}-\mathrm{Ga}$ bond, while the bulkier $\mathrm{Bm}^{\mathrm{tBu}}$ ligand is directed away from it (Figure 25).

The chemistry of other gallium containing precursors has also been explored [115]. $\mathrm{Ga}\left(\mathrm{GaCl}_{4}\right)_{2}$ reacts with $\left[\mathrm{Tl}\left(\mathrm{Tm}^{\mathrm{tBu}}\right)\right]$ to form $\left[\left(\mathrm{Tm}^{\mathrm{tBu}}\right) \mathrm{Ga}-\mathrm{GaCl}_{3}\right]$, while treatment of $\left(\mathrm{HGaCl}_{2}\right)_{2}$ with both $\mathrm{KTm}^{\mathrm{tBu}}$ or LiTm ${ }^{\mathrm{Ad}}$ gives the complex cations $\left[\left(\mathrm{Tm}^{\mathrm{R}}\right) \mathrm{Ga}-\mathrm{Ga}\left(\mathrm{Tm}^{\mathrm{R}}\right)\right]^{2+}$ $\left(\mathrm{R}={ }^{\mathrm{t}} \mathrm{Bu}, \mathrm{Ad}\right)$. The $\mathrm{Ga}-\mathrm{Ga}$ bonded species described above may be formally considered as $\left[\left(\mathrm{Tm}^{\mathrm{R}}\right) \mathrm{Ga}\right]$ adducts with various gallium(III) species. While it has not proven possible to isolate the $\left[\left(\mathrm{Tm}^{\mathrm{R}}\right) \mathrm{Ga}\right]$ complex, it can be captured by reacting $\left[\mathrm{M}\left(\mathrm{Tm}^{\mathrm{R}}\right)\right](\mathrm{M}=\mathrm{Li}, \mathrm{R}=\mathrm{Ad} ; \mathrm{M}$ $\left.=\mathrm{Na}, \mathrm{R}={ }^{\mathrm{t}} \mathrm{Bu}\right)$ with "GaI" in the presence of the Lewis acid $\mathrm{B}\left(\mathrm{C}_{6} \mathrm{~F}_{5}\right)_{3}$ to give the simple adducts $\left[\left(\mathrm{Tm}^{\mathrm{R}}\right) \mathrm{Ga}-\mathrm{B}\left(\mathrm{C}_{6} \mathrm{~F}_{5}\right)_{3}\right]$ (Figure 26). Analysis of the deviation from planarity at boron using the sum of the $\mathrm{C}-\mathrm{B}-\mathrm{C}$ angles suggests that the $\left[\left(\mathrm{Tm}^{\mathrm{R}}\right) \mathrm{Ga}\right]$ moiety is a stronger Lewis base than its indium analogue (vide infra), which might be expected on the basis of the inert pair effect becoming more pronounced as the group is descended. $\left(\mathrm{HGaCl}_{2}\right)_{2}$ also reacts with elemental sulphur in the presence of $\mathrm{K}\left(\mathrm{Tm}^{\mathrm{tBu}}\right)$ to form a $\mu$-sulfido-complex $\left[\left(\mathrm{Tm}^{\mathrm{tBu}}\right) \mathrm{Ga}-\mathrm{S}-\right.$ $\mathrm{GaCl}_{3}$ ] (Figure 26). By analogy with the pyrazole borate complexes (vide supra), it is believed that the terminal sulfido-complex, $\left[\left(\mathrm{Tm}^{\mathrm{tBu}}\right) \mathrm{Ga}=\mathrm{S}\right]$ is initially formed, which is then trapped by $\mathrm{GaCl}_{3}$.

\subsubsection{Indium}

The first soft scorpionate complex prepared with indium was the indium(III) species $\left[\operatorname{In}\left(\mathrm{Tm}^{\mathrm{Me}}\right)_{2}\right] \mathrm{I}$ resulting from the reaction of $\mathrm{InI}_{3}$ with $\mathrm{NaTm}^{\mathrm{Me}}$ [116]. Mass spectrometry confirms the presence of the $\left[\operatorname{In}\left(\operatorname{Tm}^{\mathrm{Me}}\right)_{2}\right]^{+}$cation and the sharp proton NMR spectrum indicates minimal chemical exchange on the NMR timescale. X-ray crystallography reveals an octahedral complex (Figure 27), a structural motif seen with $\mathrm{Tm}^{\mathrm{R}}$ ligands with most of the metallic $p$-block elements. The In $-\mathrm{S}$ bond distances vary only minimally (2.603(8) $2.623(8) \AA)$ and the intra-ligand bite-angles are greater than $90^{\circ}\left(\left(92.22(3)-93.86(2)^{\circ}\right)\right.$ 
while the inter ligand angles are less than $90^{\circ}\left(86.14(2)-87.65(3)^{\circ}\right)$ resulting in a slightly compressed octahedron, which is common to all species of type $\left[\mathrm{M}\left(\mathrm{Tm}^{\mathrm{R}}\right)_{2}\right]^{\mathrm{n}+}$.

Soon after, a $\mathrm{Bm}^{\mathrm{Me}}$ complex of indium(III), $\left[\operatorname{In}\left(\mathrm{Bm}^{\mathrm{Me}}\right) \mathrm{Br}_{2}\right]$ was also reported, prepared by reaction of $\mathrm{InBr}_{3}$ with $\mathrm{NaBm}^{\mathrm{Me}}$ in a 1:1 ratio in toluene [117]. The crystal structure reveals a tetrahedral coordination sphere with the first $\mathrm{S}_{2} \mathrm{Br}_{2}$ donor set at indium. The In $-\mathrm{S}$ distances $(2.4407(11) \AA)$ are substantially shorter than in the octahedral $\left[\operatorname{In}\left(\operatorname{Tm}^{\mathrm{Me}}\right)_{2}\right]^{+}$. The iodide analogues, $\left[\operatorname{In}\left(\mathrm{Bm}^{\mathrm{R}}\right) \mathrm{I}_{2}\right]\left(\mathrm{R}=\mathrm{Me},{ }^{\mathrm{t}} \mathrm{Bu}\right)$ have also been prepared [113]. Reaction of a 2:1 ratio of $\mathrm{NaBm}^{\mathrm{tBu}}$ with $\operatorname{InX} \mathrm{X}_{3}(\mathrm{X}=\mathrm{Cl}, \mathrm{Br}, \mathrm{I})$ results in the formation of $\left[\operatorname{In}\left(\mathrm{Bm}^{\mathrm{tBu}}\right)_{2} \mathrm{X}\right]$, in which the coordination geometry is trigonal bipyramidal with the halide in an equatorial position [113].

The monovalent indium complex $\left[\mathrm{In}\left(\mathrm{Tm}^{\mathrm{tBu}}\right)\right]$ is readily prepared from $\mathrm{InCl}$ and $\mathrm{KTm}^{\mathrm{tBu}}$, and is shown by X-ray crystallography to be a discrete monomeric species with trigonal pyramidal geometry [118] (Figure 28). This is in contrast with the related gallium complex, which is only isolable when stabilised by interaction with Lewis acids. MO calculations show the HOMO to be the non-bonded electron pair which is based primarily on indium with $46 \%$ $5 s$ and $32 \% 5 p$ orbital character. While this monomeric complex is stable, in the presence of $\mathrm{B}\left(\mathrm{C}_{6} \mathrm{~F}_{5}\right)_{3}$ it forms a 1:1 adduct in which the indium is shown to be a poorer donor that than its gallium analogue. The availability of the indium lone pair in $\left[\operatorname{In}\left(\mathrm{Tm}^{\mathrm{tBu}}\right)\right]$ is also illustrated in its reaction with elemental sulphur to yield a tetrasulfido complex $\left[\operatorname{In}\left(\operatorname{Tm}^{\mathrm{tBu}}\right)\left(\kappa^{2}-\mathrm{S}_{4}\right)\right]$ in which the coordination geometry is trigonal bipyramidal (Figure 29), with the axial In - S bonds being longer than the corresponding equatorial $\mathrm{In}-\mathrm{S}$ bonds.

Reaction of $\left[\operatorname{In}\left(\mathrm{Tm}^{\mathrm{tBu}}\right)\right]$ with pyridine-N-oxide or with $\mathrm{Me}_{3} \mathrm{SiN}_{3}$ results in formation of complexes $\left[\operatorname{In}\left(\kappa^{2}-\mathrm{Tm}^{\mathrm{tBu}}\right)_{2} \mathrm{X}\right]$ where $\mathrm{X}=\mathrm{Cl}$ and $\mathrm{N}_{3}$ respectively. The source of the chloride in the former is not clear, although the compound was recrystallized from $\mathrm{CHCl}_{3}$, which may be the source. Unlike the "sandwich" compounds, these are five-coordinate trigonal bipyramidal complexes with both $\mathrm{Tm}^{\mathrm{tBu}}$ ligands coordinating in a $\kappa^{2}$-mode (Figure 29).

The bulky adamantyl substituted $\mathrm{Tm}^{\mathrm{R}}$ ligand also reacts with $\mathrm{InCl}$ in a disproportionation reaction with the product being $\left[\operatorname{In}^{\mathrm{III}}\left(\mathrm{Tm}^{\mathrm{Ad}}\right)\left(\kappa^{2}-\mathrm{mim}^{\mathrm{Ad}}\right) \mathrm{Cl}\right]\left(\mathrm{mim}^{\mathrm{Ad}}=\mathrm{N}\right.$-adamantyl-2mercaptoimidazole). If the reaction is performed in the presence of $\mathrm{B}\left(\mathrm{C}_{6} \mathrm{~F}_{5}\right)_{3}$ then the Lewis acid adduct $\left[\left(\mathrm{Tm}^{\mathrm{Ad}}\right) \mathrm{In}-\mathrm{B}\left(\mathrm{C}_{6} \mathrm{~F}_{5}\right)_{3}\right]$ is formed [115]. 


\subsubsection{Thallium}

The thallium(I) complex $\left[\mathrm{Tl}\left(\mathrm{Tm}^{\mathrm{Me}}\right]\right.$ was prepared for use as a ligand transfer agent by the reaction of $\mathrm{TlNO}_{3}$ with $\mathrm{NaTm}^{\mathrm{Me}}$ in acetone [3]. During the reaction of this compound with $\mathrm{ZnI}_{2}$ small orange crystals of the thallium(III) complex $\left[\mathrm{Tl}\left(\mathrm{Tm}^{\mathrm{Me}}\right)_{2}\right] \mathrm{I}$ were obtained and characterised [119]. It was proposed that oxidation was facilitated by some $\mathrm{I}_{3}{ }^{-}$impurity in the zinc iodide, and a rational preparation, by oxidation of $\left[\mathrm{Tl}\left(\mathrm{Tm}^{\mathrm{Me}}\right)\right]$ with $\mathrm{I}_{2}$, gave $\left[\mathrm{Tl}\left(\mathrm{Tm}^{\mathrm{Me}}\right)_{2}\right]\left[\mathrm{TlI}_{4}\right]$ in good yield. Attempts to prepare this compound directly from thallium(III) nitrate were unsuccessful. The phenyl substituted analogue $\left[\mathrm{Tl}\left(\mathrm{Tm}^{\mathrm{Ph}}\right)_{2}\right] \mathrm{ClO}_{4}$ was synthesised from $\mathrm{Tl}\left(\mathrm{ClO}_{4}\right)_{3}$ and $\mathrm{LiTm}^{\mathrm{Ph}}$ [120]. The crystal structure is comparable to the parent, but in solution NMR studies suggest the presence of two different $\mathrm{Tm}^{\mathrm{Ph}}$ ligands, indicating the occurrence of some unidentified exchange process, perhaps driven by the steric demands of the phenyl-substituted ligand.

Reaction of $\mathrm{LiTm}^{\mathrm{Ph}}$ with TlOAc yielded the expected thallium(I) salt [121]. X-ray crystallography showed this to be a dimeric species, $\left[\mathrm{Tl}\left(\mathrm{Tm}^{\mathrm{Ph}}\right)\right]_{2}$ centred on a $\mathrm{Tl}_{2} \mathrm{~S}_{2}$ rectangular core (Figure 30 ). One $\mathrm{Tm}^{\mathrm{Ph}}$ sulfur from each ligand bridges the two thallium atoms, while the remaining sulfur atoms bond, one to each of the two thallium atoms. The B$\mathrm{H}$ is directed toward the centre of the $\mathrm{Tl}_{2} \mathrm{~S}_{2}$ motif suggesting a weak $\mathrm{Tl}$....H - B interaction. The compound $\left[\mathrm{Tl}\left(\mathrm{Tm}^{\mathrm{tBu}}\right)\right]_{2}$ forms a closely analogous structure [118].

Thallium(I) complexes of $\mathrm{Bm}^{\mathrm{R}}\left(\mathrm{R}=\mathrm{Me}\right.$ [120], ${ }^{\mathrm{t}} \mathrm{Bu}, \mathrm{Bz}, \mathrm{p}$-tol [122]) have also been prepared. The structure of $\left[\mathrm{Tl}\left(\mathrm{Bm}^{\mathrm{Me}}\right)\right]_{2}$ (Figure 30) shows a dimeric unit based on a rectangular $\mathrm{Tl}_{2} \mathrm{~S}_{2}$ core [121]. One sulphur atom from each ligand bridges between the two thallium atoms and the other forms a primary coordination with a thallium atom in the core, but also a weaker interaction with an adjacent $\mathrm{Tl}_{2} \mathrm{~S}_{2}$ unit to form an extended polymeric array. It is also notable that there is a significant interaction between one of the borohydride hydrogen atoms and thallium. These interactions are common in $\mathrm{Bm}^{\mathrm{R}}$ and $\mathrm{Tm}^{\mathrm{R}}$ chemistry [11] and may be thought of as 3-center-2-electron bonds. The structure of $\left[\mathrm{Tl}\left(\mathrm{Tm}^{\mathrm{tBu}}\right)\right]_{2}$ is similar [124] except that the terminal bonded sulphur atoms are unable to bridge between adjacent dimers, possibly as a result of the increased steric bulk of the ligands. This also results in a greater solubility of the $\mathrm{Tm}^{\mathrm{tBu}}$ complex.

Reaction of $\mathrm{Me}_{2} \mathrm{TlCl}$ with $\mathrm{NaBm}^{\mathrm{tBu}}$ [115] and also with the hybrid $\mathrm{NS}_{2}$ donor ligand bismethimazolylpyrazolylborate $\left(\mathrm{pzBm}^{\mathrm{Me}}\right)$ [122] result in thallium(III) dimethyl complexes of formula [Tl( $\left.\left.\mathrm{R}^{\prime} \mathrm{Bm}^{\mathrm{R}}\right) \mathrm{Me}_{2}\right]$. The pzBm ${ }^{\mathrm{Me}}$ complex is is monomeric, with a chelating $\kappa^{2}-\mathrm{S}_{2}$ ligand in which the pyrazolyl group is dangling, while the $\mathrm{Bm}^{\mathrm{tBu}}$ complex is polymeric, with 
the $\mathrm{Bm}^{\mathrm{t} \mathrm{Bu}}$ ligand bridging between thallium centres (Figure 31). In both cases the geometry around thallium is striking in that it adopts a 4-coordinate "saw-horse" geometry. The $\mathrm{C}-\mathrm{Tl}-$ $\mathrm{C}$ angles, at $157.7(2)^{\circ}\left(\mathrm{pzTm}^{\mathrm{Me}}\right)$ and $164.2(1)^{\circ}\left(\mathrm{Bm}^{\mathrm{tBu}}\right)$ are close to linear and it has been suggested that, as in the case of mercury, the large $6 s$ to $6 p$ energy gap, and the smaller $6 s$ to $5 d$ gap favours $6 \mathrm{~s}, 5 \mathrm{~d}_{\mathrm{z} 2}$ hybridisation and thus a predominantly linear bonding pattern.

The thallium(I) complex of the benzothiazole-based scorpionate (Chart 10), [Tl(Tbz)] has also been prepared [125]. Its structure is in contrast with those of $\mathrm{Tm}^{\mathrm{R}}$ and $\mathrm{Bm}^{\mathrm{R}}$ ligands in that a monomeric species is obtained. The primary motif is a $\mathrm{C}_{3}$-symmetric monomer in which the ligand is $\kappa^{3}$-coordinated. One of the sulphur atoms also bridges to an adjacent thallium atom forming a zig-zag chain. The $\mathrm{S}_{4}$ coordination sphere has a saw-horse geometry, with the bridging $\mathrm{Tl}-\mathrm{S}$ distance $(3.2502(14) \AA$ ) being longer than the primary $\mathrm{Tl}-\mathrm{S}$ distances $(2.9666(15)-3.1586(13) \AA)$. The thallium also interacts weakly with the $\pi$-system of two nearby benzothiazolyl groups.

A scorpionate formed from the heterocycle 1,3,4-thiadiazole-2-thione, hydrotris(2-thio-1,3,4thiadiazolyl)borate (Chart 11) [126] reacts (as its $\mathrm{Bu}_{4} \mathrm{~N}^{+}$salt) with TIPF 6 in THF to form a polymeric material in which infinite chains, consisting alternating four-rung $\mathrm{Tl}_{4} \mathrm{~S}_{4}$ ladders and $\mathrm{Tl}_{2} \mathrm{~S}_{2}$ rhombuses linked via the apexes, are propagated by two unique arrangements of the ligand (Figure 32 ), one on the periphery of the "tape" which has a $\mu-\left(\kappa^{2}, \kappa^{1}\right)$ binding mode and one on the face which has a $\mu_{5}-\left(\kappa^{2}, \kappa^{2}, \kappa^{2}, \kappa^{1} \kappa^{1}\right)$ binding mode. The ligand binds exclusively through its thione sulphur atoms.

\subsection{Group 14}

\subsubsection{Germanium}

There is only one report of S-donor scorpionates with germanium [127]. A series of germanium(IV) compounds, $\left[\mathrm{Ge}\left(\mathrm{R}^{\prime} \mathrm{Tm}^{\mathrm{Me}}\right)_{2}\right] \mathrm{I}_{2}$ have been prepared from $\mathrm{GeI}_{4}$ and $\mathrm{MR}^{\prime} \mathrm{Tm}^{\mathrm{Me}}$ $\left(\mathrm{M}=\mathrm{Li}, \mathrm{R}^{\prime}=\mathrm{Me},{ }^{\mathrm{n}} \mathrm{Bu}, \mathrm{Ph} ; \mathrm{M}=\mathrm{Na}, \mathrm{R}^{\prime}=\mathrm{H}\right)$ in acetone. The orange solids are air stable and have been crystallographically characterised. The structures are all octahedral, with remarkably little change in the metrical parameters as the R' groups on boron change. The complexes have been subjected to analysis by thermogravimetric analysis. This shows that, after initial solvent loss, the loss of $\mathrm{I}_{2}$ (and therefore a reduction to germanium(II)) occurs, and ultimately the substituents at boron and the methimazole rings are lost. The order of on- 
set temperatures for $\mathrm{I}_{2}$ loss (and thus a measure of the ease of reduction to germanium(II)) is ${ }^{\mathrm{n}} \mathrm{BuTm}^{\mathrm{Me}}<\mathrm{PhTm}^{\mathrm{Me}}<\mathrm{MeTm}^{\mathrm{Me}}<\mathrm{Tm}^{\mathrm{Me}}$.

\subsubsection{Tin}

A series of organotin(IV) derivatives were prepared by the reaction of $\mathrm{RSnCl}_{3}, \mathrm{R}_{2} \mathrm{SnCl}_{2}$ and $\mathrm{R}_{3} \mathrm{SnCl}$ with $\mathrm{KTm}^{\mathrm{Me}}$ resulting in compounds with empirical formulae [ $\mathrm{Sn}\left(\mathrm{Tm}^{\mathrm{Me}}\right) \mathrm{Cl}_{2} \mathrm{R}$, $\left[\mathrm{Sn}\left(\mathrm{Tm}^{\mathrm{Me}}\right) \mathrm{R}_{2} \mathrm{Cl}\right]$ and $\left[\mathrm{Sn}\left(\mathrm{Tm}^{\mathrm{Me}}\right) \mathrm{R}_{3}\right]$ respectively [128]. $\left[\mathrm{Sn}\left(\mathrm{Tm}^{\mathrm{Me}}\right) \mathrm{Cy}_{3}\right]$ has been characterised crystallographically revealing a tetrahedral coordination sphere with a $\kappa^{1}-\mathrm{Tm}^{\mathrm{Me}}$ coordination, the first example of the rarely seen monodentate coordination of the $\mathrm{Tm}^{\mathrm{Me}}$ ligand (Figure 33). The analogous complex, $\left[\mathrm{Sn}\left(\mathrm{Tm}^{\mathrm{Me}}\right) \mathrm{Ph}_{3}\right]$, has also been structurally characterised $[129,130]$. The remaining complexes are proposed to be five-coordinate on the basis of ${ }^{1} \mathrm{H}$ and ${ }^{119} \mathrm{Sn}$ NMR studies. In $\left[\mathrm{Sn}\left(\mathrm{Tm}^{\mathrm{Me}}\right) \mathrm{RCl}_{2}\right]$ the ${ }^{1} \mathrm{H}$ NMR shows three separate methimazole resonances in 1:1:1 ratio, and ${ }^{1} \mathrm{~J}\left({ }^{119} \mathrm{Sn}-{ }^{1} \mathrm{H}\right)$ coupling constants, together with the ${ }^{119} \mathrm{Sn}$ chemical shifts all suggest five-coordination. The complexes $\left[\mathrm{Sn}\left(\mathrm{Tm}^{\mathrm{Me}}\right) \mathrm{R}_{2} \mathrm{Cl}\right]$ are fluxional on the NMR timescale and five-coordination is again implied by the ${ }^{119} \mathrm{Sn}$ chemical shifts. The $\mathrm{R}-\mathrm{Sn}-\mathrm{R}(\mathrm{R}=\mathrm{Me})$ angle is estimated from the ${ }^{119} \mathrm{Sn}-{ }^{1} \mathrm{H}$ coupling constants to be approximately $125^{\circ}$ suggesting a trigonal bipyramidal arrangement.

Reaction of tin(II) bromide with $\mathrm{NaTm}^{\mathrm{Me}}$ results in a facile oxidation to yield the tin(IV) complex $\left[\mathrm{Sn}\left(\mathrm{Tm}^{\mathrm{Me}}\right)_{2}\right]\left[\mathrm{Tm}^{\mathrm{Me}}\right]_{2}$ [131]. This consists of a tin(IV) cation complexed in an octahedral array by two $\mathrm{Tm}^{\mathrm{Me}}$ ligands, with the charge balanced, unusually. by two free $\mathrm{Tm}^{\mathrm{Me}}$ anions. The tin(IV) motif can also be obtained as the iodide salt by reaction of $\mathrm{SnI}_{4}$ with $\mathrm{NaTm}^{\mathrm{Me}}$ in dichloromethane.

Reaction of $\mathrm{Me}_{2} \mathrm{SnCl}_{2}$ with $\mathrm{NaBm}{ }^{\mathrm{Me}}$ yields the unusual [ $\left.\mathrm{Sn}\left(\mathrm{Bm}^{\mathrm{Me}}\right) \mathrm{Me}_{2}\right] \mathrm{Cl}$ [132]. The primary coordination sphere consists of two sulphur atoms from the ligand and two methyl groups. There is a further weak interaction in which two tin atoms are bridged by two chloride ions $(\mathrm{d}(\mathrm{Sn}-\mathrm{Cl})=3.00(2) \AA)$ (Figure 34). This compound reacts with $\mathrm{Mo}(\mathrm{CO})_{3}\left(\eta^{6}-\mathrm{C}_{7} \mathrm{H}_{8}\right)$ to form a complex of overall composition $\left[\mathrm{Mo}\left(\mathrm{SnClMe}_{2}\right)\left(\kappa^{3}-\mathrm{H}, \mathrm{S}, \mathrm{S}-\mathrm{Bm}^{\mathrm{Me}}\right)(\mathrm{CO})_{2}\right]$ in which the $\mathrm{Bm}^{\mathrm{Me}}$ ligand has been partially transferred to the molybdenum, but a single $\mathrm{Sn}-\mathrm{S}$ bond is retained and a $\mathrm{Sn}-\mathrm{Mo}$ bond has been formed. The sulphur atom bridges the two metal atoms. The $\mathrm{Bm}^{\mathrm{Me}}$ ligand coordinates to molybdenum through two sulphur atoms and also via a $\mathrm{B}$ $\mathrm{H}^{\cdots}$ Mo interaction. 
The $\mathrm{Tm}^{\mathrm{R}}$ analogue derived from 3,4-dimethyl-1,2,4-triazole-5-thione (Tt, Chart 12) [133], can act as either an $\mathrm{N}_{3}$ donor or an $\mathrm{S}_{3}$ donor and has been dubbed a "Janus" ligand. It reacts with $\mathrm{SnCl}_{4}$ in dichloromethane to yield $\left[\mathrm{Sn}(\mathrm{Tt}) \mathrm{Cl}_{3}\right]$ which by X-ray crystallography is shown to be a distorted octahedral complex with the ligand presenting an $\mathrm{S}_{3}$ donor set. The $\mathrm{Sn}-\mathrm{Cl}$ distances are longer than in corresponding $\mathrm{Tp}^{\mathrm{R}}$ complexes, indicating a greater transinfluence of the thione donors.

\subsubsection{Lead}

The synthesis of a compound analysing as $\left[\mathrm{Pb}\left(\mathrm{Tm}^{\mathrm{Me}}\right)_{2}\right]$ has been reported, but the structure has not been determined [121]. $\mathrm{LiTm}^{\mathrm{Ph}}$ reacts with $\mathrm{Pb}\left(\mathrm{ClO}_{4}\right)_{2}$ (in a 1:1 ratio) to form the yellow complex $\left[\mathrm{Pb}\left(\mathrm{Tm}^{\mathrm{Ph}}\right)\right] \mathrm{ClO}_{4}[134]$. X-ray crystallography (Figure 35 ) shows the lead ion to be in a highly unusual 3-coordinate trigonal pyramidal environment, with a longer contact to the oxygen atoms of two perchlorate counterions, leading to a weakly associated perchlorate bridged dimer. This compound has been recognised as an important model for the mechanism of lead poisoning with respect to the zinc-containing enzyme 5-aminolevulinate dehydratase (ALAD), which is a key to biological haem synthesis, and in which zinc is coordinated in an $\mathrm{S}_{3}$ donor set. Zinc is readily displaced by lead in this enzyme system, disrupting haem synthesis. To model this, the reaction of $\left[\mathrm{Zn}\left(\mathrm{Tm}^{\mathrm{Ph}}\right) \Gamma\right]$ or $\left[\mathrm{Zn}\left(\mathrm{Tm}^{\mathrm{Ph}}\right)(\mathrm{NCMe})\right] \mathrm{ClO}_{4}$ with $\mathrm{Pb}\left(\mathrm{ClO}_{4}\right)_{2}$ in $\mathrm{MeCN}$ was shown to result in the formation of $\left[\mathrm{Pb}\left(\mathrm{Tm}^{\mathrm{Ph}}\right)\right] \mathrm{ClO}_{4}$. Although NMR studies showed that the preference for lead over zinc coordination was ca 500:1, the lead could nevertheless be replaced by zinc if NaI was added, with the concomitant precipitation of $\mathrm{PbI}_{2}$ from the mixture. An EXAFS study of lead containing synthetic peptides using $\left[\mathrm{Pb}\left(\mathrm{Tm}^{\mathrm{Ph}}\right)\right] \mathrm{ClO}_{4}$ as a model compound showed the coordination sphere in both to consist of three sulphur atoms [135].

Reaction of $\mathrm{LiTm}^{\mathrm{Ph}}$ with $\mathrm{Pb}\left(\mathrm{ClO}_{4}\right)_{2}$ in a 2:1 ratio results in formation of a compound with empirical formula $\left[\mathrm{Pb}\left(\mathrm{Tm}^{\mathrm{Ph}}\right)_{2}\right]$ [136]. The structure (Figure 35) shows a trigonal pyramidal $\left[\mathrm{Pb}\left(\mathrm{Tm}^{\mathrm{Ph}}\right)\right]^{+}$cation with a second, more weakly associated $\mathrm{Tm}^{\mathrm{Ph}}$ ligand in and "inverted $\kappa^{4}$ " configuration, with interactions between lead, the three sulphur atoms and the hydride. The $\mathrm{Pb}-\mathrm{S}$ distances are 2.8482(6) $\AA$ for the strongly bound ligand and substantially longer, at 3.1718(8) $\AA$, for the weakly bound ligand. The compound is best described as a close contact 
ion pair. This is in marked contrast to the known lead Tp complexes which form octahedral complexes bonded through nitrogen.

[137] Noth

\subsection{Group 15}

\subsubsection{Phosphorus}

Reaction of $\mathrm{PI}_{3}$ with $\mathrm{NaTm}^{\mathrm{Ph}}$ does not yield to a phosphorus complex of the Tm ligand, but rather leads to ligand degradation and the formation of an unusual heterocyclic species (Chart 13) [138] (Figure 36).

\subsubsection{Arsenic}

A single arsenic(III) containing soft scorpionate compound has been reported, originating from the reaction of $\mathrm{AsI}_{3}$ with an excess of $\mathrm{NaTm}^{\mathrm{Me}}$ in chloroform [131]. The orange crystals analyse as $\left[\mathrm{As}\left(\mathrm{Tm}^{\mathrm{Me}}\right)_{2}\right] \mathrm{I}$ and crystallography confirms the now familiar octahedral arrangement found with these ligands with $p$-block metals and metalloids. Arsenic(III) is expected to have a non-bonded electron pair, and in the absence of any evidence of distortion of the coordination sphere the As $-\mathrm{S}$ bond distances were investigated. The $\mathrm{E}-\mathrm{S}$ bond distances in $\left[\mathrm{E}\left(\mathrm{Tm}^{\mathrm{R}}\right)_{2}\right]^{\mathrm{n}+}$ were plotted against the ionic radii of $\mathrm{E}$, resulting in a straight line graph, with arsenic deviating significantly. Indeed, the As $-\mathrm{S}$ distance in $\left[\mathrm{As}\left(\mathrm{Tm}^{\mathrm{Me}}\right)_{2}\right]^{+}$was found to be some $0.12 \AA$ longer than would be expected. This is attributed to the effect of the non-directional, non-bonded electron pair [11].

\subsubsection{Antimony}

Complexes of the $\mathrm{Tm}^{\mathrm{Me}}$ ligand with antimony all show the effects of homo-directed nonbonded electron pairs [118]. In the presence of halide, two structures are observed. Reaction of $\mathrm{SbX}_{3}(\mathrm{X}=\mathrm{Br}, \mathrm{I})$ with two equivalents of $\mathrm{NaTm}^{\mathrm{Me}}$ yields yellow-orange crystalline materials which analyse as $\left[\mathrm{Sb}\left(\mathrm{Tm}^{\mathrm{Me}}\right)_{2}\right] \mathrm{X}$. However, ${ }^{1} \mathrm{H}$ NMR spectroscopy shows the species to be highly fluxional, unlike the usual octahedral $\left[\mathrm{E}\left(\mathrm{Tm}^{\mathrm{Me}}\right)_{2}\right]^{\mathrm{n}+}$ species. X-ray crystallography shows the complexes to be $\left[\mathrm{Sb}\left(\kappa^{3}-\mathrm{Tm}^{\mathrm{Me}}\right)\left(\kappa^{1}-\mathrm{Tm}^{\mathrm{Me}}\right) \mathrm{I}\right]$ which has a " $5+1$ " 
coordination geometry (Figure 37). The coordination sphere consists of one ligand bonded in the usual $\kappa^{3}$-mode, a halide ion and a second ligand bonded in a $\kappa^{1}$-mode to give a square pyramidal primary coordination geometry. A second $\mathrm{Tm}^{\mathrm{Me}}$ ligand sulphur atom interacts weakly in the sixth coordination position, while the third is directed away from the metal centre. The distortion of the coordination sphere by the non-bonded electron pair is evident. From the same reaction mixtures it is possible to obtain crystals of a second complex, the dimeric $\left[\mathrm{Sb}\left(\mathrm{Tm}^{\mathrm{Me}}\right) \mathrm{I}\left(\mu_{2}-\mathrm{I}\right)\right]_{2}$ (Figure 37 ). This suggests the possibility of a series of equilibria occurring in solution. Each antimony atom has a distorted octahedral geometry with an $\mathrm{S}_{3} \mathrm{X}_{3}$ ligand donor set. Again the effect of the non-bonded electron pair is evident. Finally, if a halide free precursor, $\mathrm{Sb}(\mathrm{OAc})_{3}$, is used then a third structural type is obtained, containing three unique $\mathrm{Tm}^{\mathrm{Me}}$ ligands (Figure 37 ). The structure has one $\kappa^{3}-\mathrm{Tm}^{\mathrm{Me}}$, one $\kappa^{2}-\mathrm{Tm}^{\mathrm{Me}}$ and one essentially non-coordinated $\mathrm{Tm}^{\mathrm{Me}}$. The primary coordination sphere is an $\mathrm{S}_{5}$-square pyramid, with a weak association of the non-coordinated ligand in the remaining coordination site. Once more, the lone pair influence is clear.

The benzothiazole derived ligand, NaTbz (Chart 10) has been reacted with $\mathrm{SbI}_{3}$ in chloroform [139]. The resulting complex, the unusual $\left[\mathrm{Sb}(\mathrm{Tbz}) \mathrm{I}_{3}\right]^{-}$anion, is unstable in solution. The main decomposition product is a cationic pentacycle, formed by loss of one thione sulphur atom with concomitant ring closure. The decomposition has been followed by NMR spectroscopy and indicates that some cleavage of the ligand $\mathrm{B}-\mathrm{N}$ bond also occurs, releasing benzothiazole. The structure of the antimony anion shows the coordination geometry to be octahedral, with the bond angles all close to $90^{\circ}$, suggesting a non-directional lone pair in this instance.

\subsubsection{Bismuth}

Bismuth complexes of the $\mathrm{Tm}^{\mathrm{Me}}$ ligand were some of the first soft scorpionate complexes reported [140]. Reaction of $\mathrm{BiCl}_{3}$ with $\mathrm{NaTm}^{\mathrm{Me}}$ in dichloromethane yielded an orange solid which analysed as $\left[\mathrm{Bi}\left(\mathrm{Tm}^{\mathrm{Me}}\right)_{2}\right] \mathrm{Cl}$, but on crystallisation the dimeric compound $\left[\mathrm{Bi}\left(\mathrm{Tm}^{\mathrm{Me}}\right) \mathrm{Cl}\left(\mu_{2}-\mathrm{Cl}\right)\right]_{2}$ was obtained. This compound is isostructural with the antimony compounds discussed above. There is significant deviation from regular octahedral geometry, as a result of a stereochemically active lone pair of electrons. An analogous compound with the bulkier $\mathrm{Tm}^{\mathrm{tBu}},\left[\mathrm{Bi}\left(\mathrm{Tm}^{\mathrm{tBu}}\right) \mathrm{Cl}\left(\mu_{2}-\mathrm{Cl}\right)\right]_{2}$, has also been reported [141]. The reaction of the 
$\left[\mathrm{Bi}\left(\mathrm{Tm}^{\mathrm{Me}}\right)_{2}\right] \mathrm{Cl}$ bulk material with $\mathrm{NaTp}$ in an effort to prepare the mixed $\left[\mathrm{Bi}\left(\mathrm{Tm}^{\mathrm{Me}}\right)(\mathrm{Tp})\right]^{+}$ cation resulted partition of the hard and soft ligands in the remarkable complex $\left[\mathrm{Bi}\left(\mathrm{Tm}^{\mathrm{Me}}\right)_{2}\right]\left[\mathrm{Na}(\mathrm{Tp})_{2}\right]$ with a regular octahedral bismuth ion coordinated by two $\mathrm{Tm}^{\mathrm{Me}}$ ligands and the unprecedented $\left[\mathrm{Na}(\mathrm{Tp})_{2}\right]^{-}$anion [140]. The compounds $\left[\mathrm{Bi}\left(\mathrm{Tm}^{\mathrm{Me}}\right)_{2}\right] \mathrm{X}(\mathrm{X}=$ $\mathrm{Cl}$, I) have been further explored [118]. Although their mass spectra show the presence of $\left[\mathrm{Bi}\left(\mathrm{Tm}^{\mathrm{Me}}\right)_{2}\right]^{+}$, they have broad ${ }^{1} \mathrm{H}$ NMR spectra, which is inconsistent with this formulation. X-ray crystallography revealed these species to be isostructural with the antimony species (vide supra), with the formulation $\left[\mathrm{Bi}\left(\kappa^{3}-\mathrm{Tm}^{\mathrm{Me}}\right)\left(\kappa^{1}-\mathrm{Tm}^{\mathrm{Me}}\right) \mathrm{I}\right]$. It appears that in the presence of coordinated halide ions the bismuth lone pairs are stereochemically active, while in a regular $\mathrm{S}_{6}$ coordination sphere these become holodirected. The reaction of $\mathrm{Bi}\left(\mathrm{NO}_{3}\right)_{3}$ with 2 equivalents of $\mathrm{Na} \mathrm{Tm}{ }^{\mathrm{Me}}$ resulted in formation of $\left[\mathrm{Bi}\left(\mathrm{Tm}^{\mathrm{Me}}\right)_{2}\right] \mathrm{NO}_{3}$ which has a regular octahedral geometry. Interestingly, unlike in the arsenic complex, the holodirected lone pair does not result in an increase in $\mathrm{Bi}-\mathrm{S}$ bond distance, probably as a result of the relativistic effects on the 6s electrons. Reaction of $\mathrm{Bi}\left(\mathrm{NO}_{3}\right)_{3}$ with one equivalent of $\mathrm{NaTm}^{\mathrm{Ph}}$ results in the complex $\left[\mathrm{Bi}\left(\mathrm{Tm}^{\mathrm{Ph}}\right)\left(\kappa^{2}-\mathrm{NO}_{3}\right)\left(\mu^{2}-\kappa^{1}-\mathrm{NO}_{3}\right)\right]$ [142]. The X-ray crystal structure (Figure 39) shows this to have facially capping $\mathrm{Tm}^{\mathrm{Ph}}$ ligand with a bidentate nitrate anion. The second nitrate anion binds in an asymmetric $\kappa^{2}$-mode with the more distant oxygen also bridging to a second bismuth centre resulting in 8-coordination at each bismuth and an overall dimeric structure. There is an open face in the coordination polyhedron where it is likely the lone pair resides.

Reaction of $\mathrm{Me}_{2} \mathrm{BiCl}$ with $\mathrm{NaTm}^{\mathrm{tBu}}$ results in the first organo-bismuth complex of a soft scorpionate, the remarkable trinuclear species $\left[\left(\mathrm{Me}_{2} \mathrm{Bi}\right)_{3}\left(\mathrm{Tm}^{\mathrm{tBu}}\right)_{2}\right]^{+}$(Figure 39). The three $\mathrm{Me}_{2} \mathrm{Bi}$ fragments are sandwiched between two $\mathrm{Tm}^{\mathrm{tBu}}$ ligands in which each thione bonds in a $\kappa^{1}$ - mode, one to each bismuth centre. The $\mathrm{S}-\mathrm{Bi}-\mathrm{S}^{\prime}$ angles are close to $180^{\circ}$ and the bismuth lone pairs are oriented to the centre of the cage generated [141].

Reaction of $\mathrm{BiI}_{3}$ with $\mathrm{NaTbz}$ in the presence of ${ }^{\mathrm{n}} \mathrm{Bu}_{4} \mathrm{NBF}_{4}$ results in formation of the $\left[{ }^{\mathrm{n}} \mathrm{BuN}\right]\left[\mathrm{Bi}(\mathrm{Tbz}) \mathrm{I}_{3}\right]$ which, unlike its antimony analogue, is stable. In every other respect the structure is identical [136]. Bismuth complexes with the 3-methyl-4-R-1,2,4-triazole-5-thione derived ligands $\left.\mathrm{Tt}^{\mathrm{R}, \mathrm{Me}}\left(\mathrm{R}=\mathrm{Me} \text { [133], Et [143], } \mathrm{Ph} \text { [144]; Chart 12)), [Bi( } \mathrm{Tt}^{\mathrm{R}, \mathrm{Me}}\right)_{2}\right] \mathrm{X}(\mathrm{X}=\mathrm{Cl}$, $\left.\mathrm{NO}_{3}\right)$ have been prepared by reaction of the sodium salts with $\mathrm{BiCl}_{3}(\mathrm{R}=\mathrm{Me})$ or $\mathrm{Bi}\left(\mathrm{NO}_{3}\right)_{3}(\mathrm{R}$ $=\mathrm{Et}, \mathrm{Ph}$ ) in methanol. In each case the complex is octahedrally coordinated in an $\mathrm{S}_{6-}$ coordination environment and the structural parameters are very similar to those in the 
previously discussed $\left[\mathrm{Bi}\left(\mathrm{Tm}^{\mathrm{Me}}\right)_{2}\right]^{+}$ion. Reaction with the related $\mathrm{Bt}^{\mathrm{Et}, \mathrm{Me}}$ results in the formally octahedral tris complex $\left[\mathrm{Bi}\left(\mathrm{Bt}^{\mathrm{Et}, \mathrm{Me}}\right)_{3}\right]$ [145]. The X-ray crystal structure reveals, however, that there are two short $\mathrm{B}-\mathrm{H} \cdots \mathrm{Bi}$ interactions, which if included in the coordination sphere imply a dodecahedral geometry. It seems likely that the non-bonded electron pair is in the region of the two $\mathrm{B}-\mathrm{H}$ moieties.

\subsection{Group 16}

\subsubsection{Tellurium}

Of all the group 16 elements only a single tellurium complex of $\mathrm{Tm}^{\mathrm{Me}}$ has been prepared, by the reaction of $\left[\mathrm{Te}(\mathrm{tu})_{4}\right] \mathrm{Cl}_{2}$ (tu $=$ thiourea) with $\mathrm{NaTm}^{\mathrm{Me}}$ in chloroform [114]. The resulting complex, $\left[\mathrm{Te}\left(\mathrm{Tm}^{\mathrm{Me}}\right)_{2}\right]$, has a square planar coordination geometry, with both $\mathrm{Tm}$ ligands adopting a $\kappa^{2}$-coordination mode. In this case there are no secondary interactions either with the pendant sulphur atoms or the borohydride moieties. This is in accord with tellurium(II) having two non-bonded electron pairs. The ${ }^{1} \mathrm{H}$ NMR spectrum of this molecule shows broad resonances, suggesting significant fluxionality.

\section{Complexes of the p-Block Elements with Se-donor Scorpionate Ligands.}

Only two p-block complexes of the selenium analogue of the $\mathrm{Tm}^{\mathrm{Me}}\left(\mathrm{TSe}^{\mathrm{Me}}\right)$ ligand (Chart 15) have been reported to date [146], namely the complexes $\left[\mathrm{M}\left(\mathrm{TSe}^{\mathrm{Me}}\right)_{2}\right]\left[\mathrm{MCl}_{4}\right]$ prepared by reaction of the potassium salt of the ligand and $\mathrm{MCl}_{3}(\mathrm{M}=\mathrm{Ga}, \mathrm{In})$. Both have a regular octahedral structure with the ligand coordinating in a $\kappa^{3}-\mathrm{Se}, \mathrm{Se}, \mathrm{Se}$ mode.

\section{Conclusions}

The chemistry of the anionic poly-heterocyclic borate ligands with the p-block elements is extensive. The application of pyrazolyl borates (and related ligands) to main group chemistry dates right back to the discovery of these ligands. Groups 13 and 14 are now comprehensively covered, but the group 15 element chemistry is sparse and with group 16 elements it is non-existent. With the more recently introduced methimazolyl borate ligands the coverage is more extensive, with a considerable body of group 15 chemistry, and one example of a group 16 compound, in addition to the extensive coverage of groups 13 and 14 . 
In some cases the pyrazolylborate complexes are sensitive to hydrolysis, leading to decomposition of the complex accompanied by ligand degradation. By contrast, the methimazolyl borate complexes are predominantly stable, to the extent that their synthesis can be performed under aerobic conditions and using wet solvents without any detriment. This stability most likely arises from a combination of the softer S-donor atoms, which match many of the lower main group metals and metalloids better than the hard $\mathrm{N}$-donor atoms of the pyrazolyl borates, and the $\pi$-donor ability of the S-donor ligands which results in greater coordinative saturation than in the simple $\sigma$-donor $\mathrm{N}$-donors. It seems likely that it should be possible to fill many of the gaps which exist in the coverage with both sets of ligands. The applications of these complexes are relatively sparse, but various areas of application can be envisaged. There has been an explosion of interest in main group catalysed reactions and it seems feasible that complexes such as those described should have potential in this area. The ability of these fragments to support unusual functionalities (such as terminal chalcogen complexes, hydrides, etc) also points to potential use in fundamental main group chemistry. It will be fascinating to observe the continued development of this area of chemistry in the coming years.

\section{References}

[1] S. Trofimenko, J. Am. Chem. Soc. 88 (1966) 1842-1844.

[2] M. Garner, J. Reglinski, I. Cassidy, M.D. Spicer, A.R. Kennedy, J. Chem. Soc., Chem. Commun. (1996) 1975-1976.

[3] D.R. Armstrong, I.D. Cassidy, M. Garner, J. Reglinski, M.D. Spicer, J. Chem. Soc., Dalton Trans. (1999) 2119-2126.

[4] a) M. D. Curtis, K.-B. Shiu, W. M. Butler, Organometallics 2 (1983) 1475-1477;

b) M. D. Curtis, K.-B. Shiu, W. M. Butler, J. Am. Chem. Soc. 108 (1986) 1550-1561.

[5] S. Trofimenko, The Coordination Chemistry of Polypyrazolylborate Ligands, Imperial College Press, London, 1999.

[6] C. Pettinari, Scorpionates II: Chelating Borate Ligands, Imperial College Press, London, 2008. 
[7] S. Trofimenko, Progr. Inorg. Chem., 34 (1986) 115 - 210

[8] S. Trofimenko, Chem. Rev., 93 (1993) 943 - 980.

[9] C. Pettinari, C. Santini, Comprehensive Coordination Chemistry II, 1 (2004) 159 -

[10] G. Parkin, New J. Chem., 31 (2007) 1996 - 2014.

[11] J. Reglinski, M.D. Spicer, Eur J. Inorg. Chem., (2009) 1553 - 1574.

[12] J. Reglinski and M.D. Spicer, Current Bioactive Compounds, 5 (2009) $264-276$.

[13] D.L. Reger, Coord. Chem. Rev. 147 (1996) 571-595.

[14] G. Parkin, Adv. Inorg. Chem. 42 (1995) 291-393

[15] C. Janiak, Coord. Chem. Rev., 163 (1997) 107 - 216.

[16] C. Janiak, Main Group Met. Chem., 21 (1998) 33 - 49.

[17] A.H. Cowley, C.J. Carrano, R.L. Geerts, R.A. Jones, C.M. Nunn, Angew. Chem., Int. Ed. Engl. 27 (1988) 277-278.

[18] R. Han, A. Looney, G. Parkin, J. Am. Chem. Soc. 111 (1989) 7276-7278.

[19] A. Looney, G. Parkin, Polyhedron 9 ( 1990) 265-276.

[20] S. Trofimenko, J.C. Calabrese, J.S. Thompson, Inorg. Chem. 26 (1987) 1507-1514.

[21] M.H. Chisholm, N.W. Eilerts, J.C. Huffman, Inorg. Chem. 35 (1996) 445-450.

[22] C.H. Dungan, W. Maringgele, A. Meller, K. Niedenzu, H. Nöth, J. Serwatowska, J. Serwatowski, Inorg. Chem. 30 (1991) 4799-4806.

[23] J. Lewiński, J. Zachara, P. Goś, E. Grabska, T. Kopeć, I. Madura, W. Marciniak, I. Prowotorow, Chem., Eur. J. 6 (2000) 3215-3227.

[24] M. Zimmermann, J. Takats, G. Kiel, K.W. Törnroos, R. Anwander, Chem. Commun. (2008) 612-614.

[25] H.V.R. Dias, W. Jin, Inorg. Chem. 42 (2003) 5034-5036. 
[26] D.L. Reger, S.J. Knox, L. Lebioda, Inorg. Chem. 28 (1989) 3093-3095.

[27] R.E. Marsh, Inorg. Chem. 29 (1990) 1449-1450.

[28] D.L. Reger, S.J. Knox, L. Lebioda, Organometallics 9 (1990) 2218-2222.

[29] D.L. Reger, Y. Ding, Organometallics 12 (1993) 4485-4492.

[30] K. Yurkerwich, Y. Rong, G. Parkin, Acta Crystallogr. Sect. C, C69 (2013) 963 - 967.

[31] M.C. Kuchta, J.B. Bonanno, G. Parkin, J. Amer. Chem. Soc. 118 (1996) 10914-10915.

[32] H.V.R. Dias, W. Jin, Inorg. Chem. 39 (2000) 815-819.

[33] M.C. Kuchta, G. Parkin, J. Chem. Soc., Dalton Trans. (1998) 2279-2280.

[34] J.C. Green, J.L. Suter, J. Chem. Soc., Dalton Trans. (1999) 4087-4092.

[35] K. Yurkerwich, G. Parkin, J. Clust. Sci. 21 (2010) 225-234.

[36] D.L. Reger, D.G. Garza, A.L. Rheingold, G.P.A. Yap, Organometallics 17 (1998) 3624-3626.

[37] A. Frazer, B. Piggott, M. Harman, M. Mazid, M.B. Hursthouse, Polyhedron 11 (1992) 3013-3017.

[38] B.K. Nicholson, R.A. Thomson, F.D. Watts, Inorg. Chim. Acta 148 (1988) 101-104.

[39] D.L. Reger, S.J. Knox, A.L. Rheingold, B.S. Heggerty, Organometallics 9 (1990) 2581-2587.

[40] D.L. Reger, S.S. Mason, A.L. Rheingold, R.L. Ostrander, Inorg. Chem. 33 (1994) 1803-1810.

[41] D.L. Reger, S.S. Mason, L.B. Reger, A.L. Rheingold, R.L. Ostrander, Inorg. Chem. 33 (1994) 1811-1816.

[42] A. Frazer, B. Piggott, J. Chem. Soc., Dalton Trans., (1999) 3483 - 3486.

[43] D. Reger, P.S. Coan, Inorg. Chem., 34 (1995) 6226 - 6227. 
[44] W. Kläui, N. Liedtke, W. Peters, Mag. Res. Chem., 37 (1999) 867 - 870.

[45] W. Kläui, W. Peters, N. Liedtke, S. Trofimenko, A.L. Rheingold, R.D. Sommer, Eur. J. Inorg. Chem., (2001) $693-699$.

[46] A. Frazer, B. Piggott, J. Am. Chem. Soc., 116 (1994) $4127-4128$.

[47] H.V.R. dias, L. Hai, W. Jin, S.G. Bott, Inorg. Chem., 34 (1995) 1973 - 1974.

[48] H.V.R. Dias, W. Jin, Inorg. Chem., 35 (1996) 267 - 268.

[49] M.C. Kuchta, G. Parkin, Main Group Chem., 1 (1996) 291 - 295.

[50] M.C. Kuchta, G. Parkin, J. Am. Chem. Soc., 117 (1995) $12651-12652$.

[51] D.L. Reger, S.S. Mason, A.L. Rheingold, B.S. Haggerty, F.P. Arnold, Organometallics, 13 (1994) 5049 - 5053.

[52] C. Janiak, S. Temizdemir, T.G. Scharmann, Z. Anorg. Allgem. Chem., 624 (1998) 755 -766 .

[53] E. Craven, E. Mutlu, D. Lundberg, S. Temizdemir, S. Dechert, H. Brombacher, C. Janiak, Polyhedron, 21 (2002) 553 - 562.

[54] A.L. Rheingold, G.P.A. Yap, L.N. Zakharov, S. Trofimenko, Eur. J. Inorg. Chem., (2002) $2335-2343$.

[55] A.L. Rheingold, L.M. Liable-Sands, J.A. Golen, G.P.A. Yap, S. Trofimenko, Dalton Trans., (2004) $598-604$.

[56] K. Michiue, R.F. Jordan, Organometallics, 23 (2004) 460 - 470.

[57] K. Fujisawa, H. Takisawa, Acta Crystallogr. Sect. C, C69 (2013) 986 - 989.

[58] A.L. Rheingold, C.D. Incarvito, S. Trofimenko, J. Chem. Soc., Dalton Trans., (2000) $1233-1234$.

[59] G.R. Motson, O. Mamula, J.C. Jeffry, J.A. McCleverty, M.D. Ward, A. von Zelewsky, J. Chem. Soc., Dalton Trans., (2001) 1389 - 1391. 
[60] M.H. Chisholm, J.C. Gallucci, G. Yaman, Chem. Commun., (2006) 1872 - 1874.

[61] M.H. Chisholm, J.C. Gallucci, G. Yaman, Inorg. Chem., 46 (2007) 8676 - 8683.

[62] S. Kealey, N.J. Long, A.J.P. White, A.D. Gee, Dalton Trans., (2007) 4763 - 4765.

[63] S. Kealey, N.J. Long, P.W. Miller, A.J.P. White, A.D. Gee, Dalton Trans., (2008) $2677-2679$.

[64] E.R. Sirianni, G.P.A. Yap, E.S. Akturk, K.H. Theopold, Acta Crystallogr. Sect. C., C69 (2013) $947-953$.

[65] D.A. Bardwell, J.C. Jeffery, J.A. McClevery, M.D. Ward, Inorg. Chim. Acta, 267 (1998) $323-328$.

[66] J.S. Fleming, E. Psillakis, S.M. Couchman, J.C. Jeffery, J.A. McClevery, M.D. Ward, J. Chem. Soc., Dalton Trans., (1998) 537 -543.

[67] K.V. Mann, J.C. Jeffery, J.A. McClevery, M.D. Ward, Polyhedron, 18 (1999) 721 727.

[68] G.M. Davies, J.C. Jeffery, M.D. Ward, New. J. Chem., 27 (2003) 1550 - 1553.

[69] H. Adams, S.R. Batten, G.M. Davies, M.B. Duriska, J.C. Jeffery, P. Jensen, J. Lu, G.R. Motsen, S.J. Coles, M.B. Hursthouse, M.D. Ward, Dalton Trans., (2005) 1910 1923.

[70] N. Zhao, M.J. van Stipdonk, C. Bauer, C. Campana, D.M. Eichhorn, Inorg. Chem., 46 (2007) $8662-8667$.

[71] N. Zhao, J.C. Bullinger, M.J. van Stipdonk, C.L. Stern, D.M. Eichhorn, Inorg. Chem., 47 (2008) $5945-5950$.

[72] D.M. Johnson, D.M. Eichhorn, C.E. Moore, T.M. Mwania, N. Zhao, J. Chem. Crystallogr., 42 (2012) $746-751$.

[73] H.V.R. Dias, X. Wang, H.V.K. Diyabalanage, Inorg. Chem., 44 (2005) 7322 - 7324. 
[74] E. Despagnet-Ayoub, K. Jacob, L. Vendier, M. Etienne, E. Alvarez, A. Caballero, M.M. Diaz-Requejo, P.J. Perez, Organometallics, 27 (2008) 4779 - 4787.

[75] W.A. King, G.P.A. Yap, C.D. Incarvito, A.L. Rheingold, K.H. Theopold, Inorg. Chim. Acta, 362 (2009) 4493 - 4499.

[76] B.K. Munoz, W-S. Ojo, K. Jacob, N. Romero, L. Vendier, E. Despagnet-Ayoub, M. Etienne, New J. Chem., 38 (2014) 2451 - 2461.

[77] W-S. Ojo, K. Jacob, E. Despagnet-Ayoub, B.K. Munoz, S. Gonell, L. Vendier, V-H. Nguyen, M. Etienne, Inorg. Chem., 51 (2012) 2893 - 2901.

[78] M. Kitamura, Y. Takenaka, T. Okuno, R. Holl, B. Wünsch, Eur. J. Inorg. Chem., (2008) 1188-1192.

[79] H.V.R. Dias, J. Thankamani, Acta Crystallogr. Sect. C, C69 (2013) 959 - 962)

[80] C. Janiak, L. Braun, F. Girgsdies, J. Chem. Soc., Dalton Trans., (1999) 3133 - 3136.

[81] H.V.R. Dias, X. Wang, Polyhedron, 23 (2004) 2533 - 2539.

[82] C. Chen, R.F. Jordan, J. Organomet. Chem., 695 (2010) 2543 - 2547.

[83] J.L. Kisko, T. Hascall, C. Kimblin, G. Parkin, J. Chem. Soc., Dalton Trans., (1999) $1929-1935$.

[84] S. Guo, J.W. Bats, M. Bolte, M. Wagner, J. Chem. Soc., Dalton Trans., (2001) 3572 3576.

[85] J. Zagermann, M.C. Kuchta, K. Merz, N. Metzler-Nolte, Eur. J. Inorg. Chem., (2009) $5407-5412$.

[86] A.L. Rheingold, L.M. Liable-Sands, J.A. Golan, S. Trofimenko, Eur. J. Inorg. Chem., (2003) $2767-2773$.

[87] A.L. Rheingold, L.N. Zakharov, S. Trofimenko, Inorg. Chem., 42 (2003) 827 - 833.

[88] G.P.A. Yap, F. Jove, J. Urbano, E. Alvarez, S. Trofimenko, M.M. Diaz-Requejo, P.J. Perez, Inorg. Chem., 46 (2007) $780-787$. 
[89] C. Janiak, S. Temizdemir, S. Dechert, Inorg. Chem. Commun., 3 (2000) $271-275$.

[90] P. Ghosh, A.L. Rheingold, G. Parkin, Inorg. Chem., 38 (1999) $5464-5467$.

[91] R. Han, P. Ghosh, P.J. Desrosiers, S. Trofimenko, G. Parkin, J. Chem. Soc., Dalton Trans. (1997) $3713-3717$.

[92] P. Ghosh, P.J. Desrosiers, G. Parkin, J. Am. Chem. Soc., 120 (1998) 10416 - 10422.

[93] D.L. Reger, P.S. Coan, Inorg. Chem., 35 (1996) 258 - 260.

[94] A.C. Filippou, P. Portius, G. Kociok-Kohn, J. Chem. Soc. Chem. Commun., (1998) $2327-2328$.

[95] B.K. Nicholson, J. Organomet. Chem., 265 (1984) 153 - 157.

[96] S.K. Lee, B.K. Nicholson, J. Organomet. Chem., 309 (1986) 257 - 265.

[97] G.G. Lobbia, F. Bonati, P. Cecchi, A. Cingolani, A. Lorenzotti, J. Organomet. Chem., 378 (1989) 139 - 146.

[98] G.G. Lobbia, F. Bonati, P. Cecchi, D. Leonesi, J. Organomet. Chem., 391 (1990) 155 -163 .

[99] G.G. Lobbia, F. Bonati, P. Cecchi, A. Cingolani, A. Lorenzotti, C. Pettinari, J. Organomet. Chem., 403 (1991) 317 - 323.

[100] S. Calogero, L. Stievano, G.G. Lobbia, A. Cingolani, P. Cecchi, G. Valle, Polyhedron, 14 (1995) 1731 - 1740.

[101] O-S. Jung, J.H. Jeong, Y.S. Sohn, J. Organomet. Chem., 399 (1990) 235 - 246.

[102] O-S. Jung, J.H. Jeong, Y.S. Sohn, J. Organomet. Chem., 439 (1992) 23 - 32.

[103] K. Niedenzu, H. Noth, J. Serwatowska, J. Serwatowski, Inorg. Chem., 30 (1991) 3249 -3254 .

[104] K. Mashima, T. Oshiki, K. Tani, Organometallics, 16 (1997) 2760 - 2762. 
[105] A.H. Cowley, R.L. Geerts, C.M. Nunn, C.J. Carrano, J. Organomet. Chem., 341 (1988) C27-C30.

[106] M.N. Hansen, K. Niedenzu, J. Serwatowska, J. Serwatowski, K.R. Woodrum, Inorg. Chem., 30 (1991) $866-868$.

[107] D.L. Reger, Y. Ding. Polyhedron, 13 (1994) 869 - 871.

[108] D.L. Reger, S.J. Knox, M.F. Huff, A.L. Rheingold, B.S. Haggerty, Inorg. Chem., 30 (1991) $1754-1759$.

[109] D.L. Reger, M.F. Huff, A.L. Rheingold, B.S. Heggarty, J. Am. Chem. Soc., 114 (1992) $579-584$

[110] D.L. Reger, Y. Ding, A.L. Rheingold, R.L. Ostrander, Inorg. Chem., 33 (1994) 4226 $-4230$.

[111] D.L. Reger, T.D. Wright, M.D. Smith, A.L. Rheingold, S. Kassel, T. Concolino, B. Rhagitan, Polyhedron, 21 (2002) 1795 - 1807.

[112] C. Janiak, S. Temizdemir, T.G. Scharmann, A. Schmalstieg, J. Demtschuk, Z. Anorg. Allgem. Chem., 626 (2000) 2053 - 2062.

[113] A. Caneschi, A. Dei, D. Gatteschi, L. Sorace, K. Vostrikova, Angew. Chem. Int. Ed., 39 (2000) $246-248$.

[114] C.A. Dodds, A.R. Kennedy, J. Reglinski, M.D. Spicer, Inorg. Chem., 43 (2004) 394 395.

[115] K. Yurkerwich, F. Coleman, G. Parkin, Dalton Trans., 39 (2010) 6939 - 6942.

[116] K. Yurkerwich, D. Buccella, J.G. Melnick, G. Parkin, Chem. Sci., 1 (2010) 210 214.

[117] K. Yurkerwich, M. Yurkerwich, G. Parkin, Inorg. Chem., 50 (2011) 12284 - 12295.

[118] C.A. Dodds, J. Reglinski, M.D. Spicer, Chem. Eur. J. 12 (2006) 931 - 939. 
[119] S.C. Hill, D.S. Jones, D. Rabinovich, Acta Crystallogr., Sect. E E62 (2006) m702 $\mathrm{m} 704$.

[120] K. Yurkerwich, D. Buccella, J.G. Melnick, G. Parkin, Chem. Commun., (2008) 3305 -3307 .

[121] P.A. Slavin, J. Reglinski, M.D. Spicer, A.R. Kennedy, J. Chem. Soc., Dalton Trans., (2000) $239-240$.

[122] C. Kimblin, B.M. Bridgewater, T. Hascall, G. Parkin, J. Chem. Soc., Dalton Trans., (2000) $1267-1274$.

[123] C. Kimblin, B.M. Bridgewater, T. Hascall, G. Parkin, J. Chem. Soc., Dalton Trans., (2000) $891-897$.

[124] H.M. Alvarez, P.A.Gillespie, C.D. Gause, A.L. Rheingold, J.A. Golen, D. Rabinovich, Polyhedron, 23 (2004) 617 - 622.

[125] J.F. Ojo, P.A. Slavin, J. Reglinski, M. Garner, M.D. Spicer, A.R. Kennedy, S.J. Teat, Inorg. Chim. Acta, 313 (2001) $15-20$.

[126] J.R. Gardinier, R.M. Silva, C. Gwengo, S.V. Lindeman, Chem. Commun., (2007) $1524-1526$.

[127] D. Wallace, K. Chalmers, C.A. Dodds, I.A. Stepek, D.R. Armstrong, L.E.A. Berlouis, J. Reglinski, M.D. Spicer, Eur. J. Inorg. Chem., (2014) 2569 - 2575.

[128] C. Santini, M. Pellei, G.G. Lobbia, C. Pettinari, A. Drozdov, S. Troyanov, Inorg. Chim. Acta, 325 (2001) $20-28$.

[129] N.C. Lloyd, B.K. Nicholson, A.L. Wilkins, R. Thomson, Chem. In New Zealand, (2002) $53-54$.

[130] A.F. Hill, M.K. Smith, Chem. Commun., (2005) 1920 - 1922.

[131] C.A. Dodds, M. Jagoda, J. Reglinski, M.D. Spicer, Polyhedron, 23 (2004) 445 - 450.

[132] M.R.St-J. Foreman, A.F. Hill, M.K. Smith, N. Tshabang, Organometallics, 24 (2005) $5224-5226$. 
[133] P.J. Bailey, M. Lanfranchi, L. Marchiò, S. Parsons, Inorg. Chem., 40 (2001) 5030 5035.

[134] B.M. Bridgewater, G. Parkin, J. Am. Chem. Soc., 122 (2000) 7140 - 7141.

[135] J.S. Magyar, T-C. Weng, C.M. Stern, D.F. Dye, B.W. Rous, J.C. Payne, B.M. Bridgewater, A. Mijovilovich, G. Parkin, J.M. Zaleski, J.E. Penner-Hahn, H.A. Goodwin, J. Am. Chem. Soc., 127 (2005) 9495 - 9505.

[136] B.M. Bridgewater, G. Parkin, Inorg. Chem. Commun., 3 (2000) 534 - 536.

[137] M. Imran, A. Mix, B. Neumann, H.-G. Stammler, U. Monkowius, P. Grundlinger, N.W. Mitzel, Dalton Trans., 44 (2015) 924 - 937.

[138] R.R. Nair, A. Marckwordt, S.T. Lutta, M. Schwalbe, A. Biernat, D.R. Armstrong, A.J.B. Watson, A.R. Kennedy, J. Reglinski, M.D. Spicer, Chem. Eur. J., 19 (2013) $13561-13568$.

[139] R.R. Nair, D. Moore, A.R. Kennedy, J. Reglinski, M.D. Spicer, Inorg. Chem., 53 (2014) $10276-10282$.

[140] J. Reglinski, M.D. Spicer, M. Garner, A.R. Kennedy, J. Am. Chem. Soc., 121 (1999) 2317-2318.

[141] M. Bao, T. Hayashi, S. Shimada, Dalton Trans., (2004) 2055 - 2056.

[142] M. Shu, J. Cui, J. Sun, Appl. Organomet. Chem., 19 (2005) $184-185$.

[143] M. Careri, L. Elviri, M. Lanfranchi, L. Marchiò, C. Mora, M.A. Pellinghelli, Inorg. Chem., 42 (2003) $2109-2114$.

[144] M. Lanfranchi, L. Marchiò, C. Mora, M.A. Pellinghelli, Inorg. Chim. Acta, 357 (2004) $367-375$.

[145] R. Cammi, M. Lanfranchi, L. Marchiò, C. Mora, C. Paiola, M.A. Pellinghelli, Inorg. Chem., 42 (2003) $1769-1778$.

[146] M. Minoura, V.K. Landry, J.G. Melnick, K. Pang, L. Marchiò, G. Parkin, Chem. Commun., (2006) 3990 - 3992. 
Chart 1: Structures of key scorpionate ligands.<smiles>[H][Z8](n1cccn1)n1cccn1</smiles>

$\mathrm{Bp}$<smiles>[BH-](n1cccn1)n1cccn1</smiles>

$\mathrm{Tp}$<smiles></smiles>

pzTp<smiles>[2H][B-](n1nccc1C)n1nc(C)cc1C</smiles><smiles></smiles>

Chart 2: Nomenclature of Tp and Tm ligands.<smiles>[R]c1nn([B-]([R])(n2cccn2)n2cccn2)c([R])c1[R]</smiles>

$\mathrm{R}^{\prime} \mathrm{Tp} \mathrm{R}^{\mathrm{R}}$<smiles>[R]n1ccn([B-]([R])(n2ccn([R])c2=S)n2ccn([R])c2=S)c1=S</smiles> 
Chart 3. The $\kappa^{3}-\mathrm{S}, \mathrm{S}, \mathrm{H}$ bonding mode of methimazoylborate ligands.

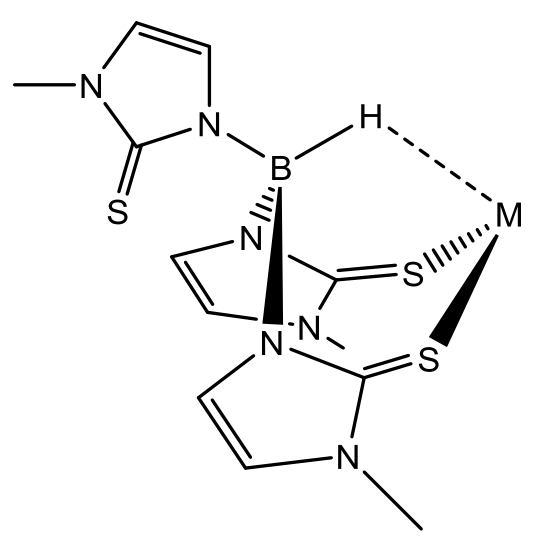

Chart 4.

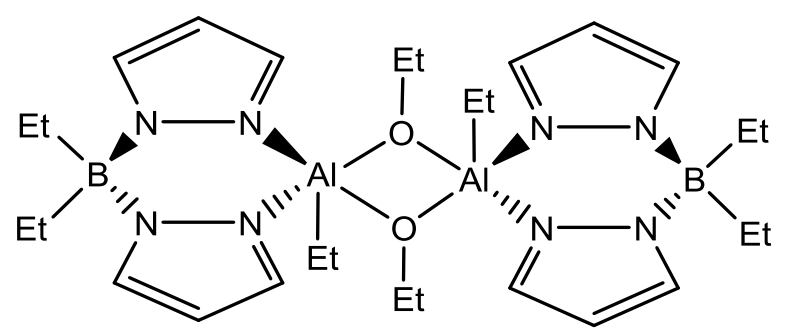

Chart 5

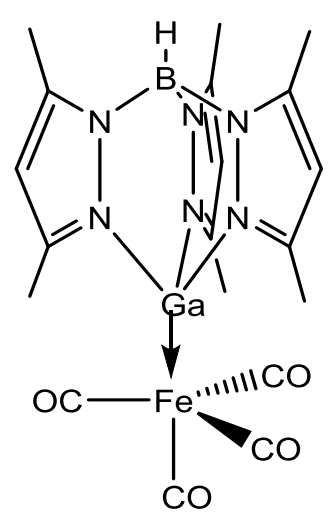


Chart 6.

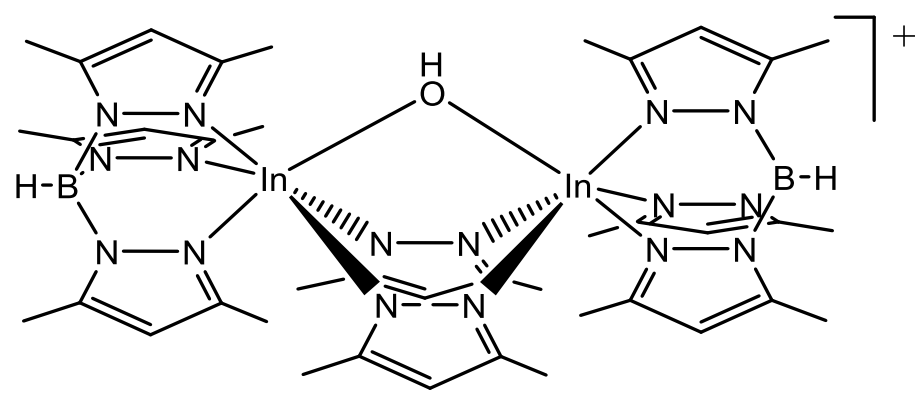

Chart 7

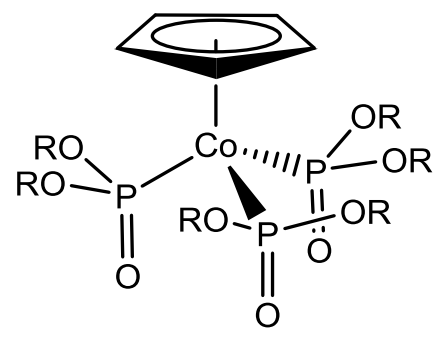

Chart 8

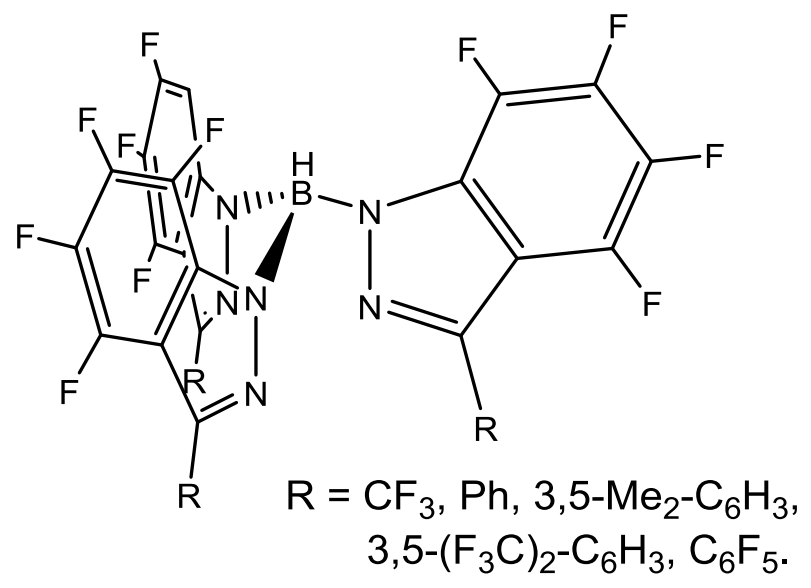


Chart 9.<smiles></smiles>

Chart 10.

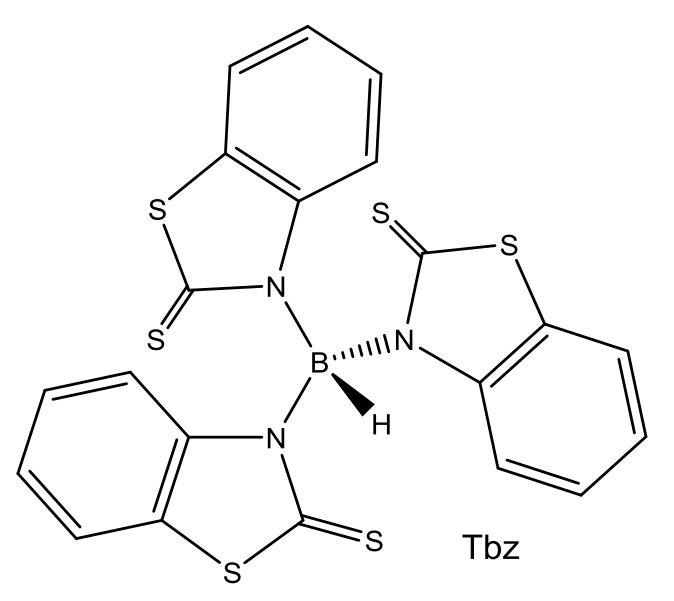

Chart 11.

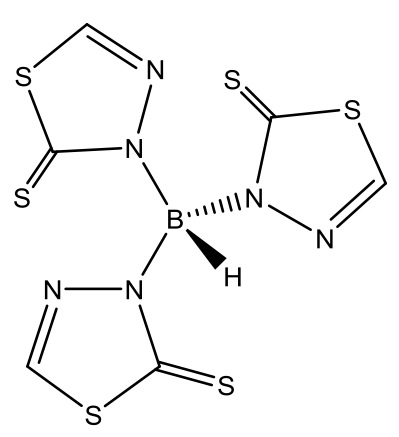


Chart 12

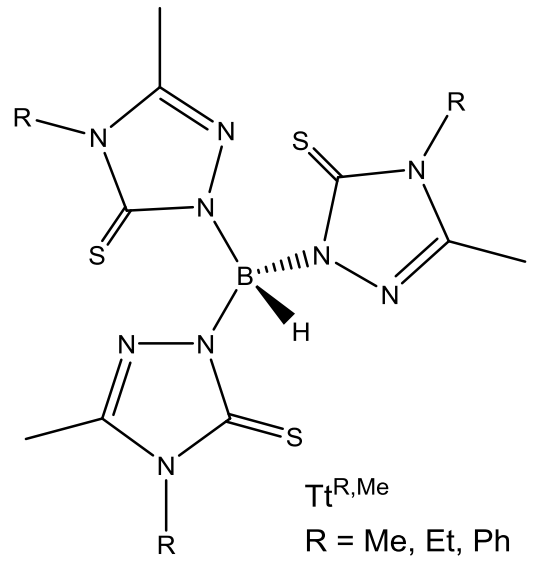

Chart 13

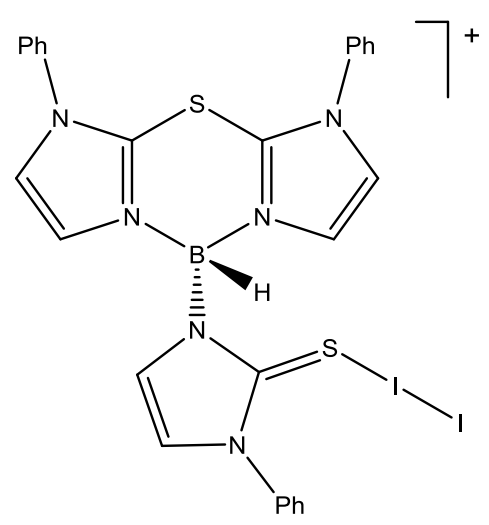

Chart 14

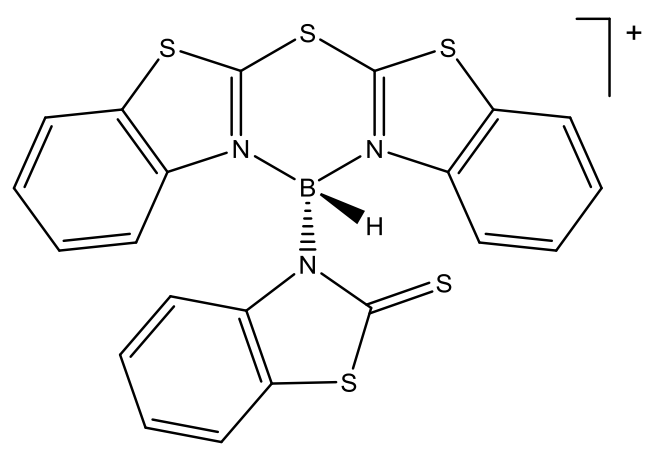


Chart 15

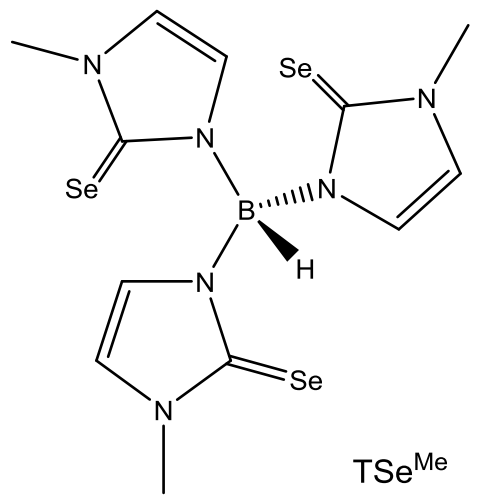


Scheme 1. Thermal isomerisation of $\left[\mathrm{Al}\left(\mathrm{Bp}^{3-\mathrm{tBu}}\right) \mathrm{R}_{2}\right]$.
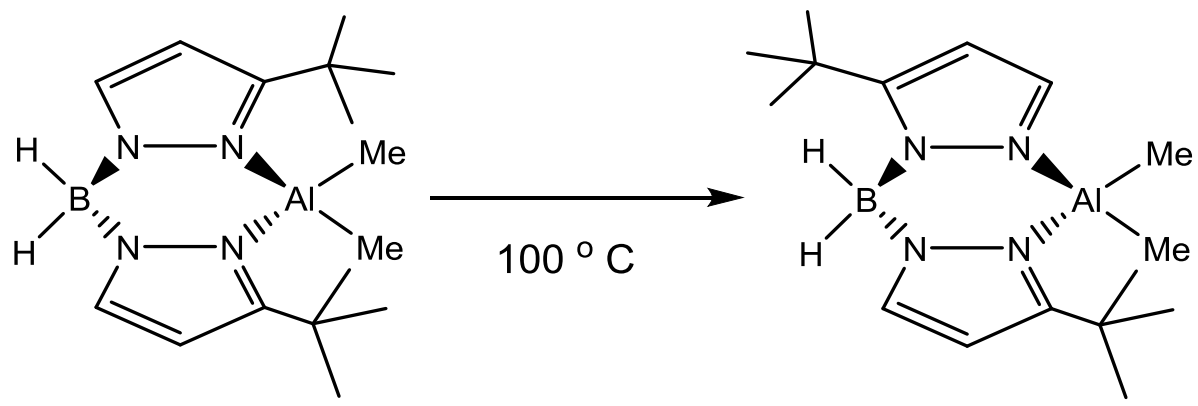

Scheme 2. The methyl gallium chemistry of the dihydridobis(pyrazolyl)borate ligand.

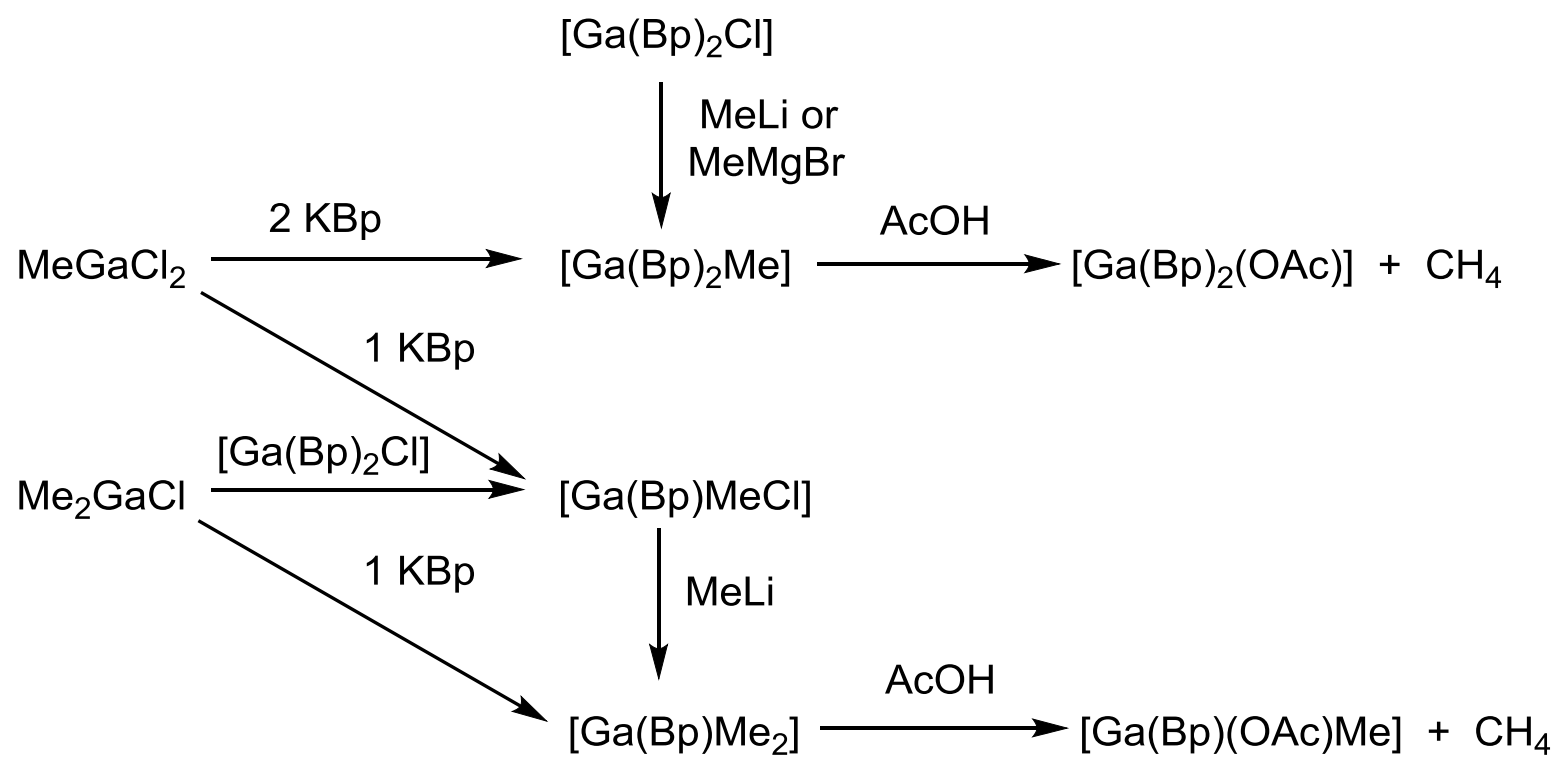

Scheme 3. The oxidative chemistry of $\left[\operatorname{In}\left(\mathrm{Tp}^{\mathrm{tBu} 2}\right)\right]$.

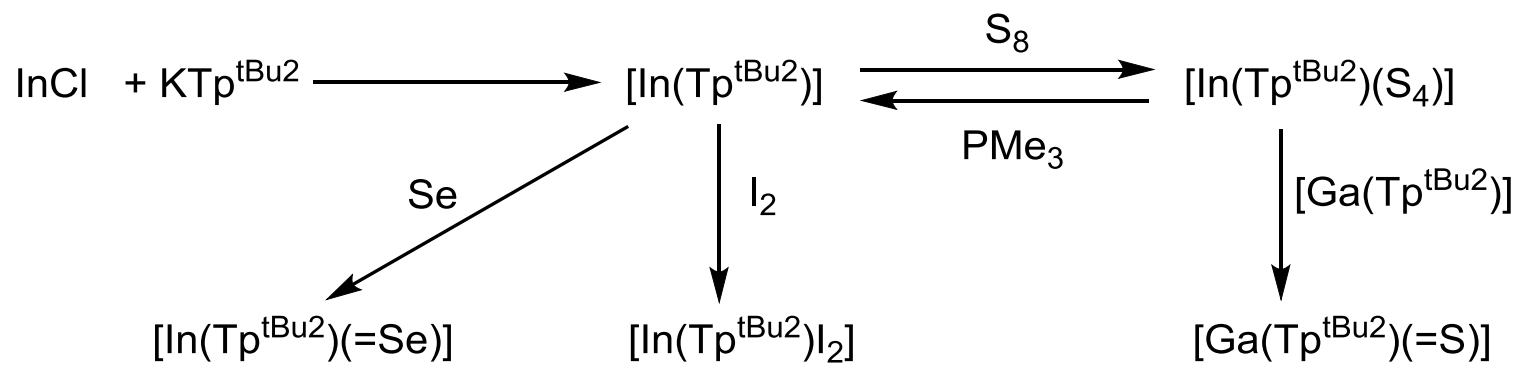


Figure 1. The X-ray crystal structures of the $\left[\mathrm{Al}\left(\mathrm{Tp}^{3 \mathrm{tBu}, 5 \mathrm{Me}}\right) \mathrm{Me}\right]^{+}$cation (left) and $\left[\mathrm{Al}\left(\mathrm{Tp}^{3,5 \mathrm{CF} 3}\right) \mathrm{Me}_{2}\right]$ (right) showing the secondary $\mathrm{F} \ldots \mathrm{Al}$ interactions.
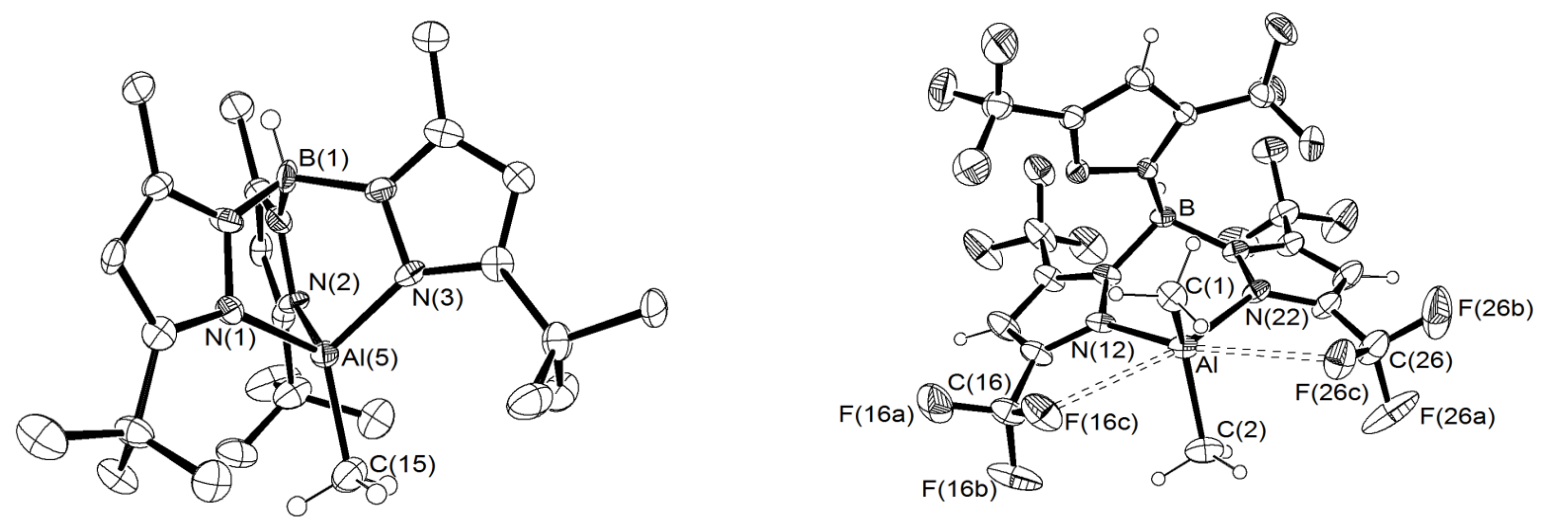

Figure 2. The X-ray crystal structures of $\left[\mathrm{Ga}(\mathrm{Bp})_{2} \mathrm{Cl}\right]$ (left) and $\left[\mathrm{Ga}(\mathrm{Tp})_{2}(\mathrm{OAc})\right]$ (right).
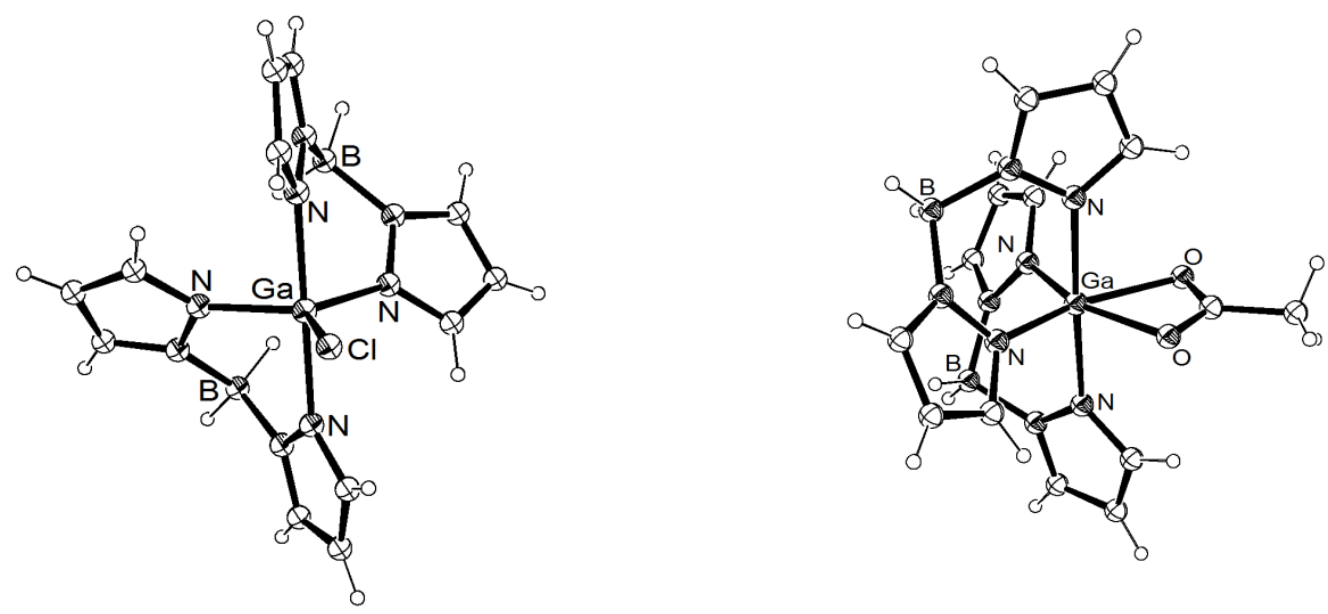
Figure 3. X-ray crystal structures of $\left.\left[\mathrm{Ga}\left(\mathrm{Tp}^{*}\right) \mathrm{Me}_{2}\right](\mathrm{left}), \mathrm{Ga}\left(\kappa^{3}-\mathrm{pzTp}\right)\left(\kappa^{2}-\mathrm{pzTp}\right) \mathrm{Me}\right]$ (centre) and $\left[\mathrm{Ga}\left(\mathrm{Tp}^{*}\right) \mathrm{MeCl}\right]$ (right).
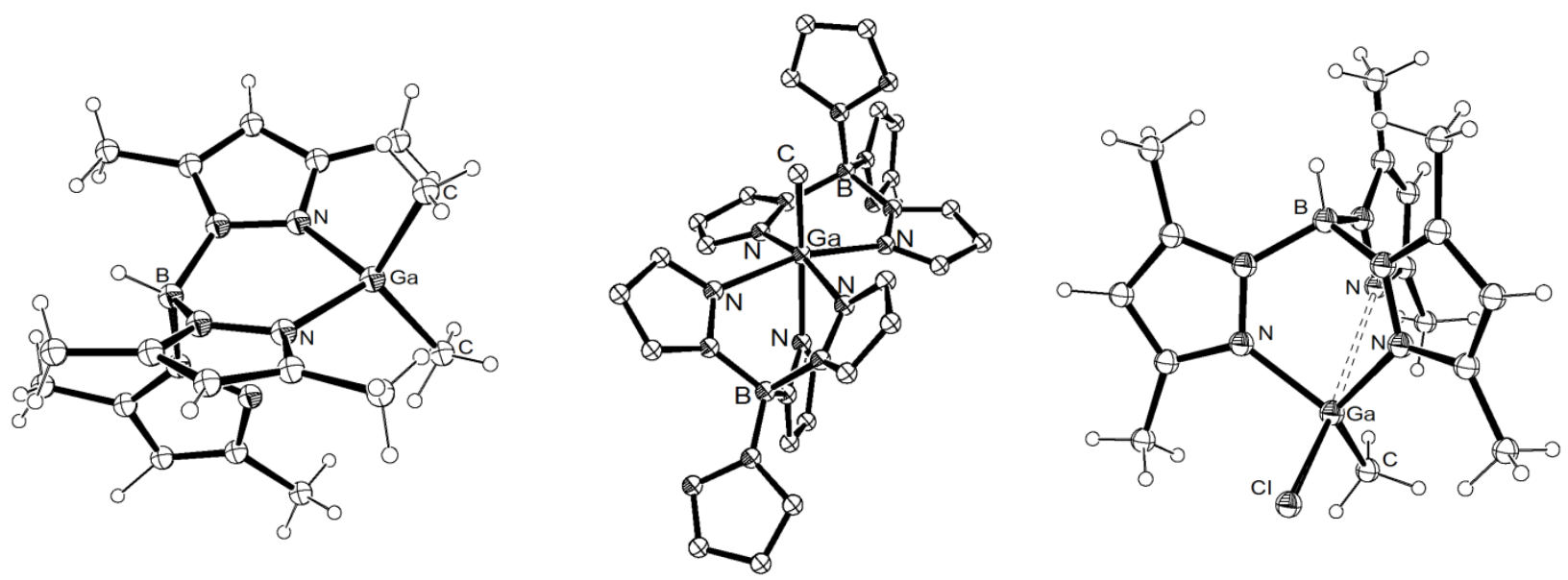

Figure 4. X-ray crystal structure of $\left[\mathrm{Ga}\left(\mathrm{Tp}^{\mathrm{tBu} 2}\right) \mathrm{S}\right]$.

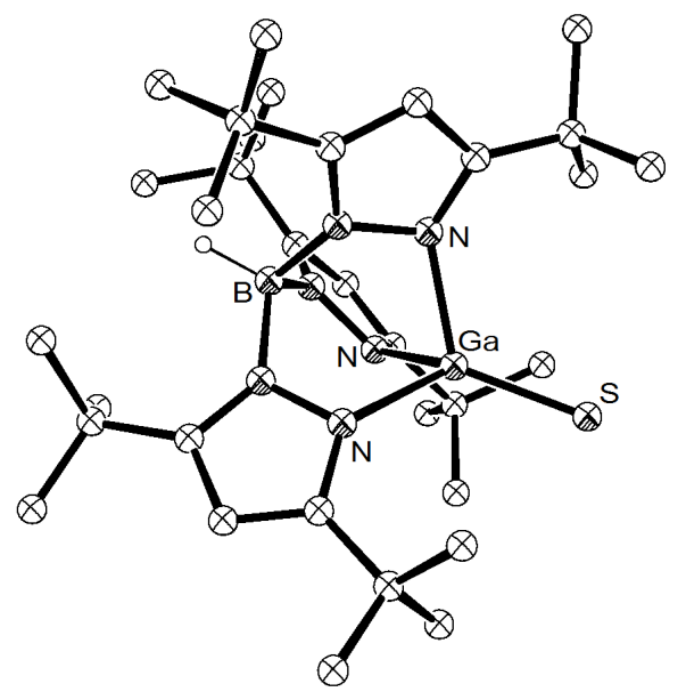




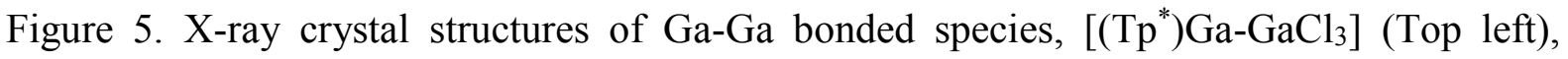
$\left[\left(\mathrm{Tp}^{*}\right) \mathrm{Ga}-\mathrm{Ga}\left(\mathrm{Tp}^{*}\right)\right]$ (Top right) and $\left[\left(\mathrm{Tp}^{*}\right) \mathrm{GaGaI}_{2} \mathrm{GaI}_{2} \mathrm{Ga}\left(\mathrm{Tp}^{*}\right)\right]$.
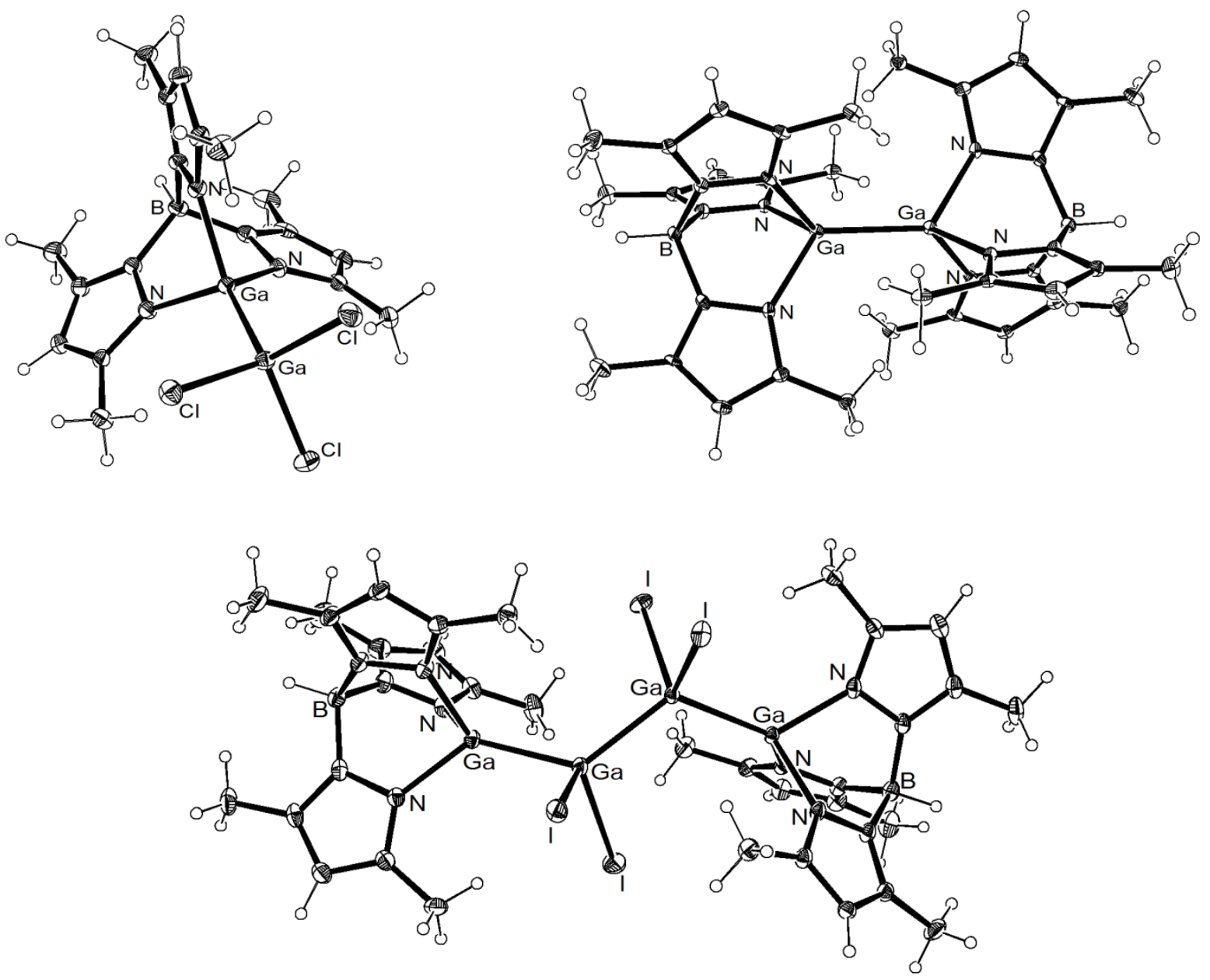

Figure 6. X-ray Crystal structure of $\left[\operatorname{In}(\mathrm{Bp})_{3}\right]$.

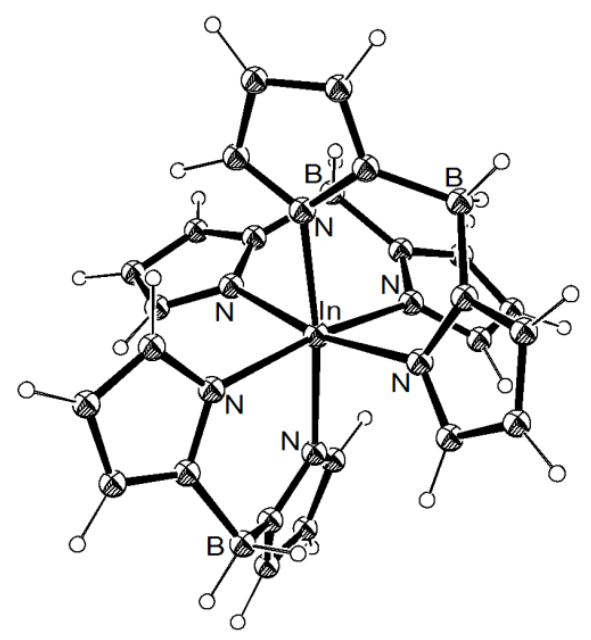


Figure 7 . The $\mathrm{X}$-ray crystal structure of $[\operatorname{In}(\mathrm{Bp}) \mathrm{Me}(\mu-\mathrm{Cl})]_{2}$.

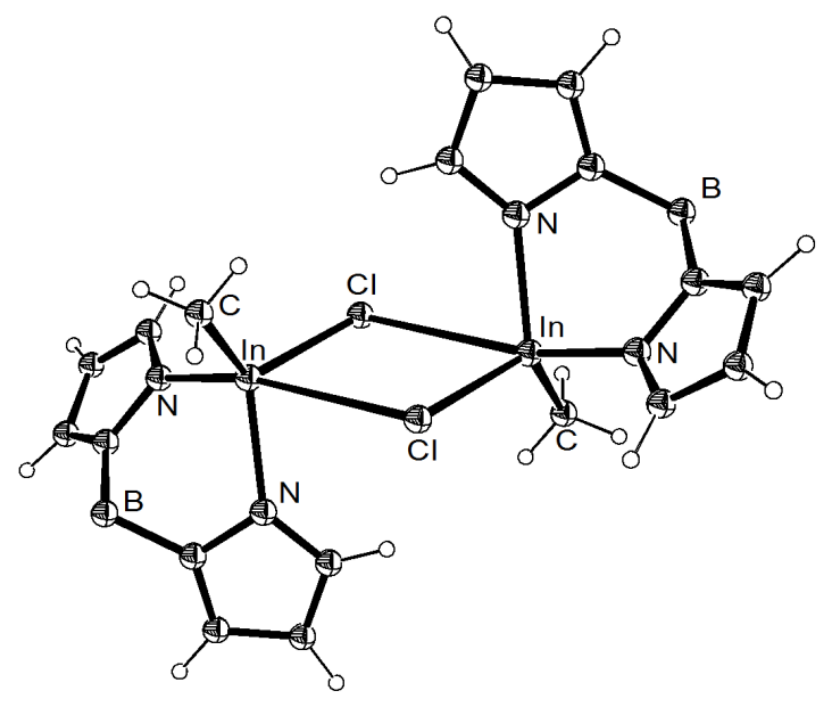

Figure 8. X-ray crystal structure of $\left[\operatorname{In}\left(\mathrm{Tp}^{3 \mathrm{Ph}}\right)\right]$.

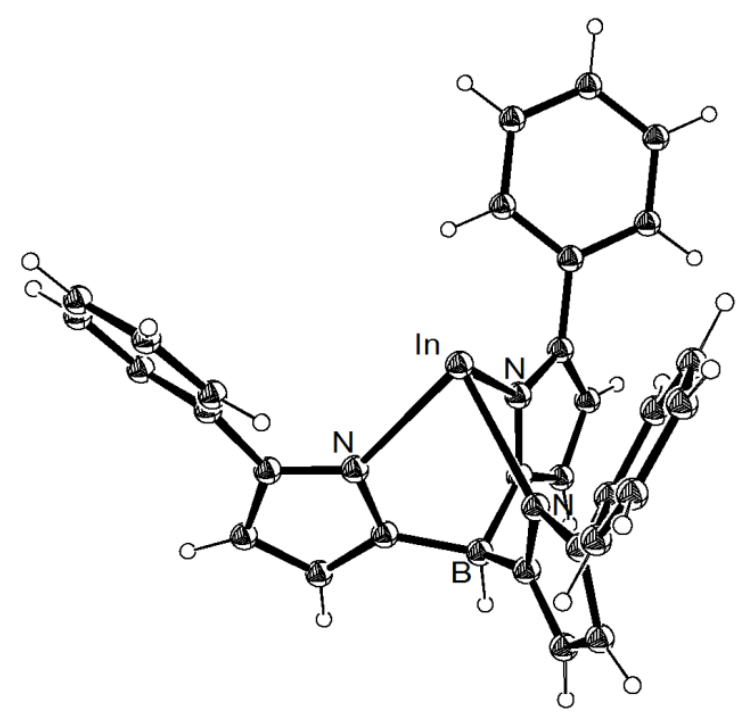


Figure 9. X-ray crystal structure of $\left[\operatorname{In}\left(\mathrm{Tp}^{\mathrm{tBu} 2}\right)(=\mathrm{Se})\right]$.

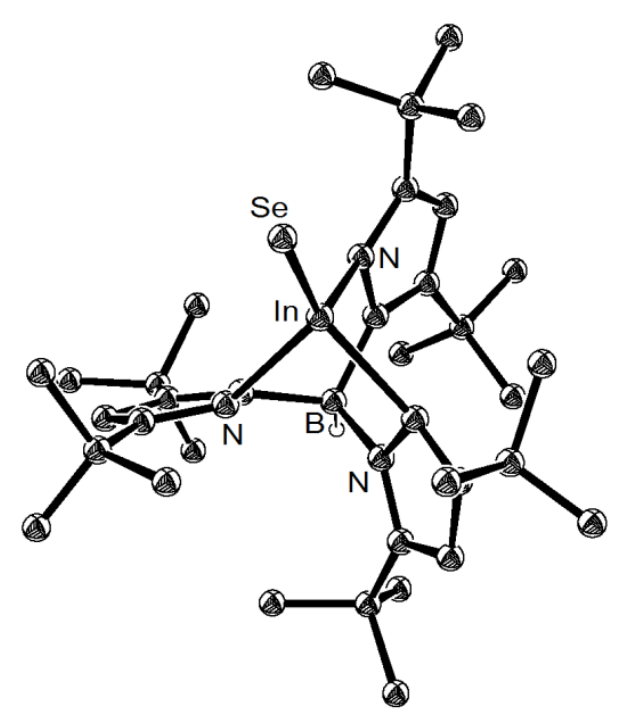

Figure 10. X-ray crystal structure of [Tl(Tp)].

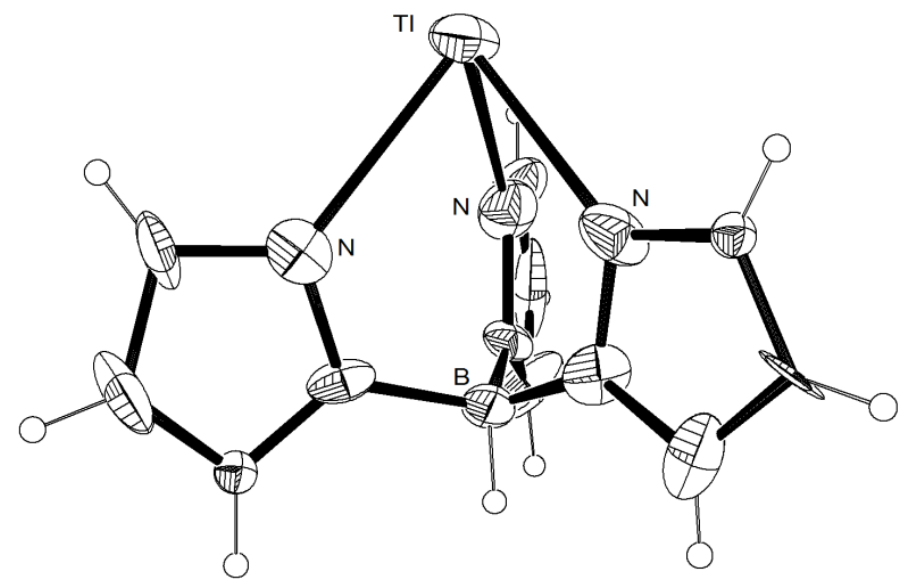


Figure 11. X-ray crystal structures of TlTp complexes with pendent arms capable of secondary coordination to the metal ion. Top left hydridotris(3-\{2-(pinene[4,5]-2pyridyl)\}pyrazolyl)borate; top right, hydridotris(3-\{1,1-dimethyl-2-methoxyethyl $\}$ pyrazoyl)borate; below, hydridotris(3-\{2-(diphenylphosphinophenyl)\}-5-methylpyrazolyl) borate, with the phenyl substituents on phosphorus omitted for clarity.

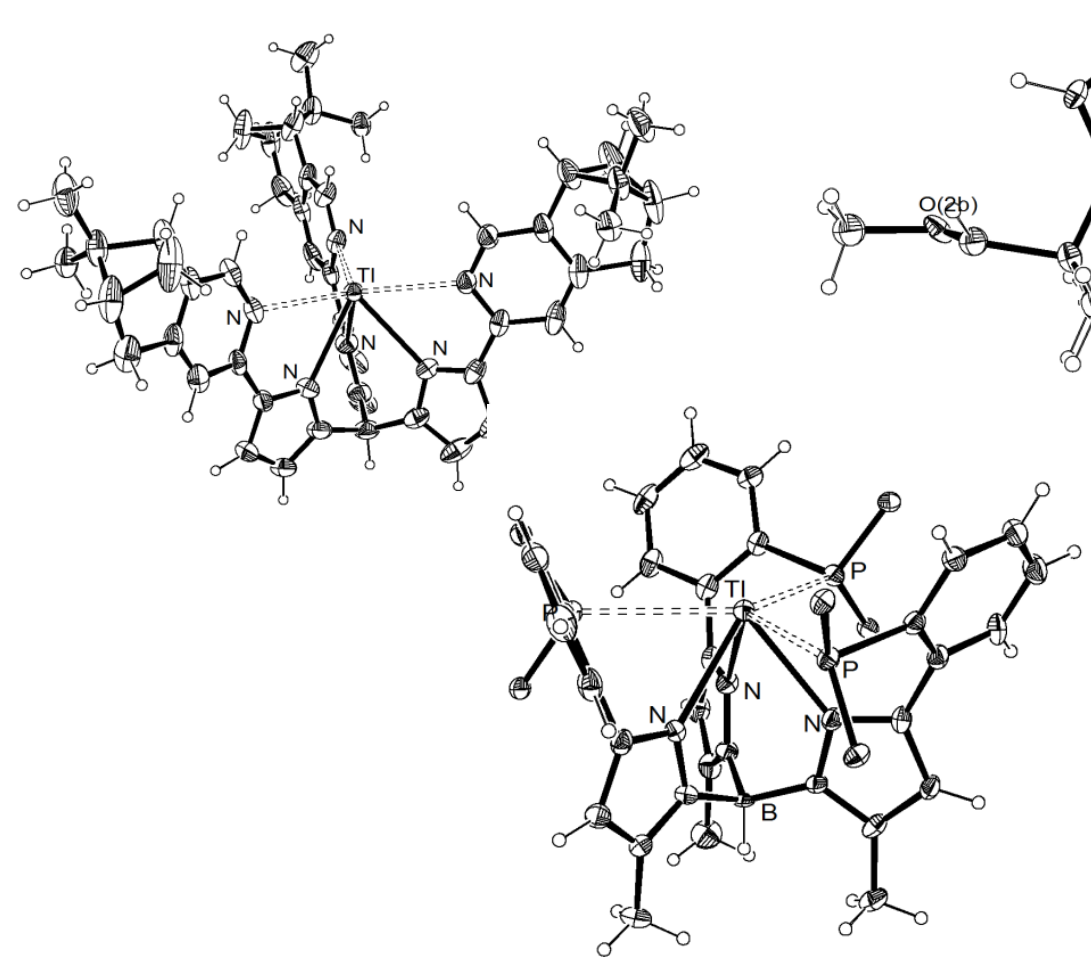

Figure 12. X-ray crystal structure of $\left[\mathrm{Tl}\left(\mathrm{Bp}^{3-\mathrm{py}}\right)\right]$ showing the monomeric unit (left) and the 1D chain formed by association through neighbouring 3-pyridyl units (right).
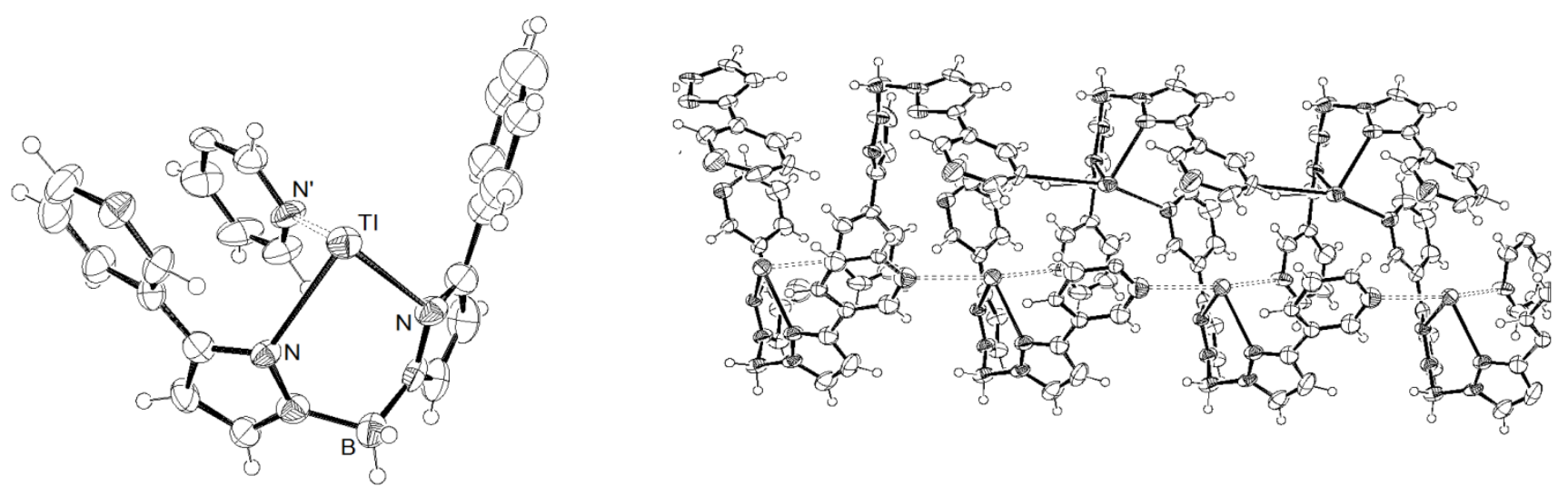
Figure 13. The X-ray crystal structure of $\left[\mathrm{Tl}\left(\mathrm{Tp}^{3-\mathrm{py}}\right)\right]$ showing the monomeric unit (left) and the 2D sheet formed by association through neighbouring 3-pyridyl units (right).
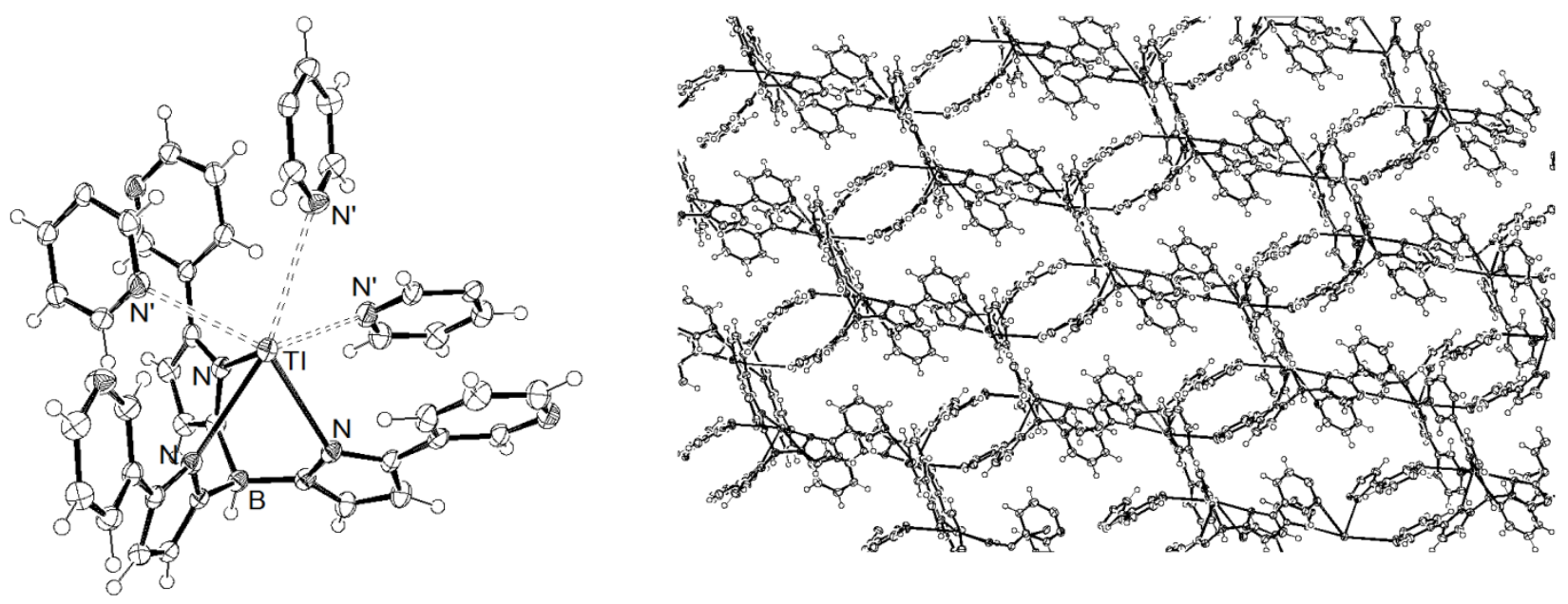

Figure 14. The X-ray crystal structure of the thallium(I) complex of a perfluorinated Tp ligand, hydridotris(3-trifluoromethyl-4,5,6,7-tetrafluoroindazolyl)borate.

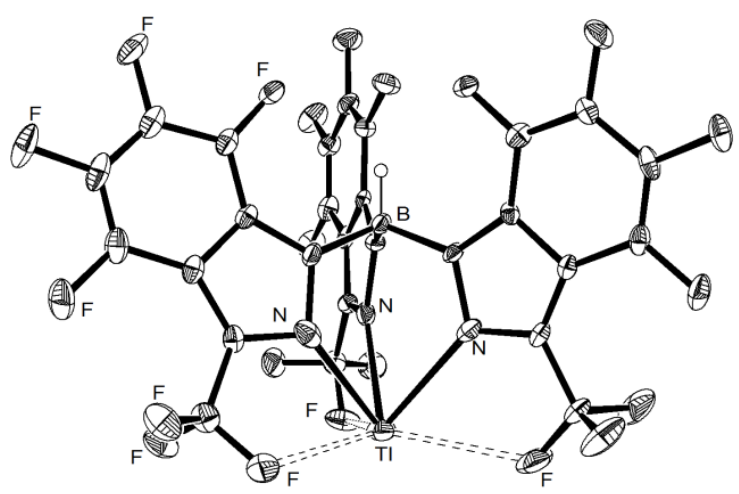


Figure 15. The X-ray crystal structure of the thallium complex of a perfluorinated Tp ligand, hydridotris(3 \{pentafluorophenyl\}-4,5,6,7-tetrafluoroindazolyl)borate, showing the 3,5 isomerisation of one of the pyrazoles.

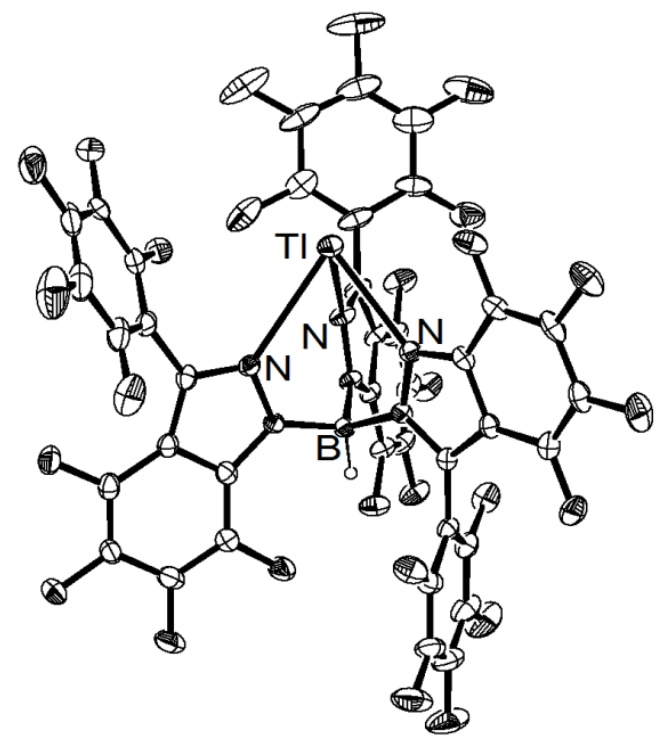

Figure 16. X-ray Crystal Structures of [Tl(cymatreneTp)] (left) showing the linkages with adjacent metal and ligand atoms resulting in a 1D helical polymer, and [Tl(methylcymantreneTp)] (right), which forms a cyclic tetramer.
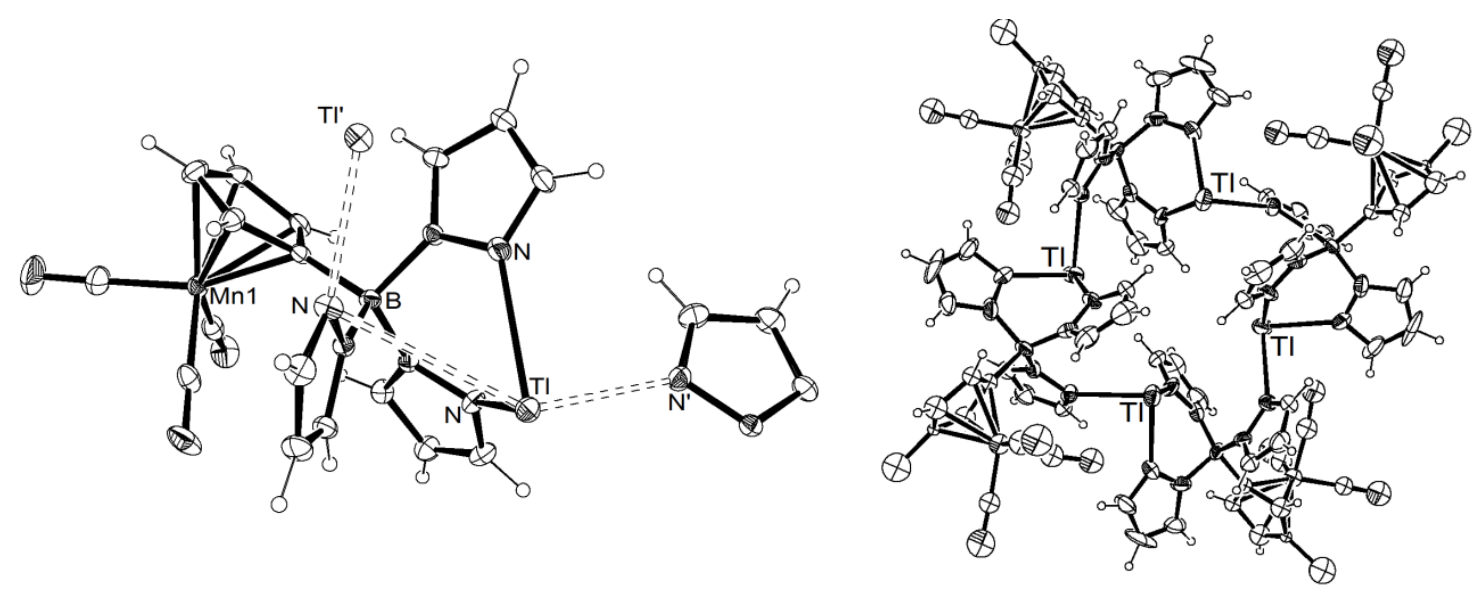
Figure 17. The X-ray crystal structure of $\left[\mathrm{Ge}\left(\mathrm{Tp}^{*}\right) \mathrm{N}_{3}\right]$.

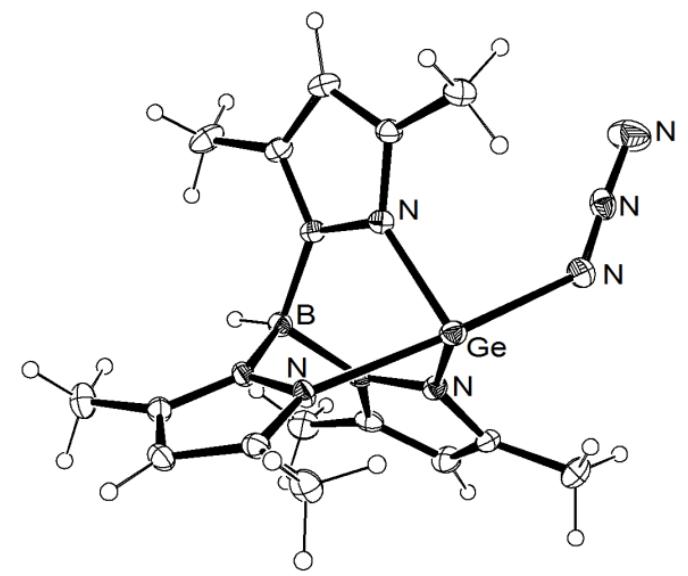

Figure 18. The X-ray crystal structure of the hydrolysis product derived from $\left[\mathrm{Sn}\left(\mathrm{Et}_{2} \mathrm{Bp}\right) \mathrm{Me}_{2}\right]$.

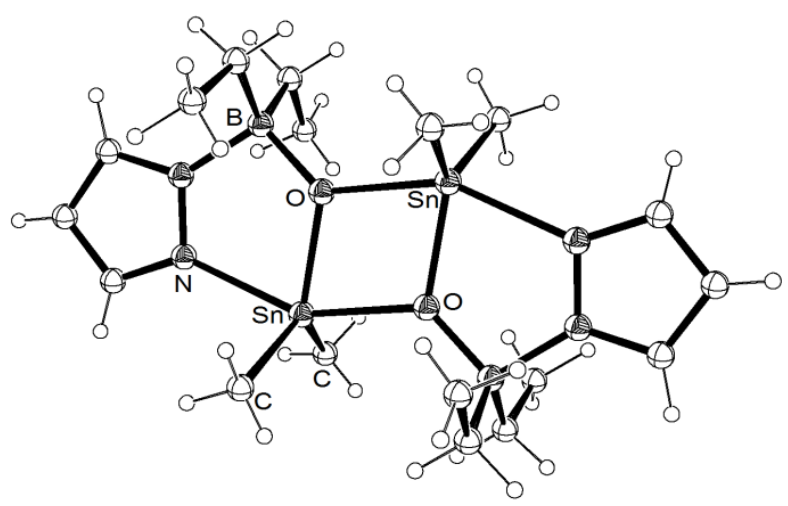

Figure 19. The X-ray crystal structure of $\left[\operatorname{Sn}(\mathrm{Tp})_{2}\right]$, illustrating the effect of the stereochemically active lone pair.

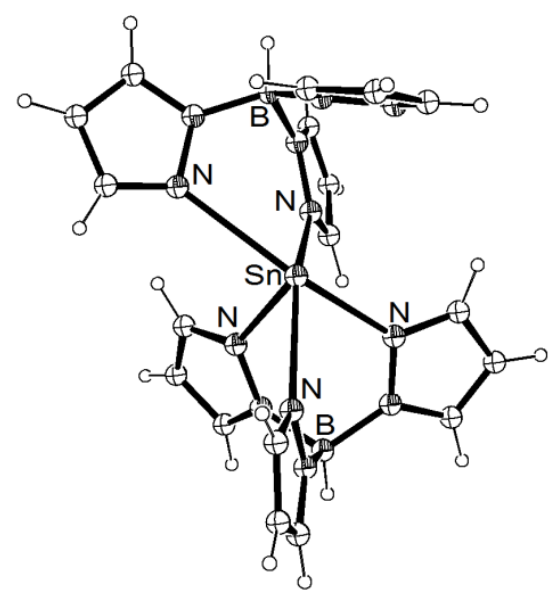


Figure 20. The X-ray crystal structures of $\left[\mathrm{Pb}\left(\kappa^{2}(\mathrm{pzTp})_{2}\right]\right.$ (left), $\left[\mathrm{Pb}(\mathrm{Tp})_{2}\right]$ (centre) and $\left[\mathrm{Pb}\left(\mathrm{Tp}^{*}\right)_{2}\right]$ (right).
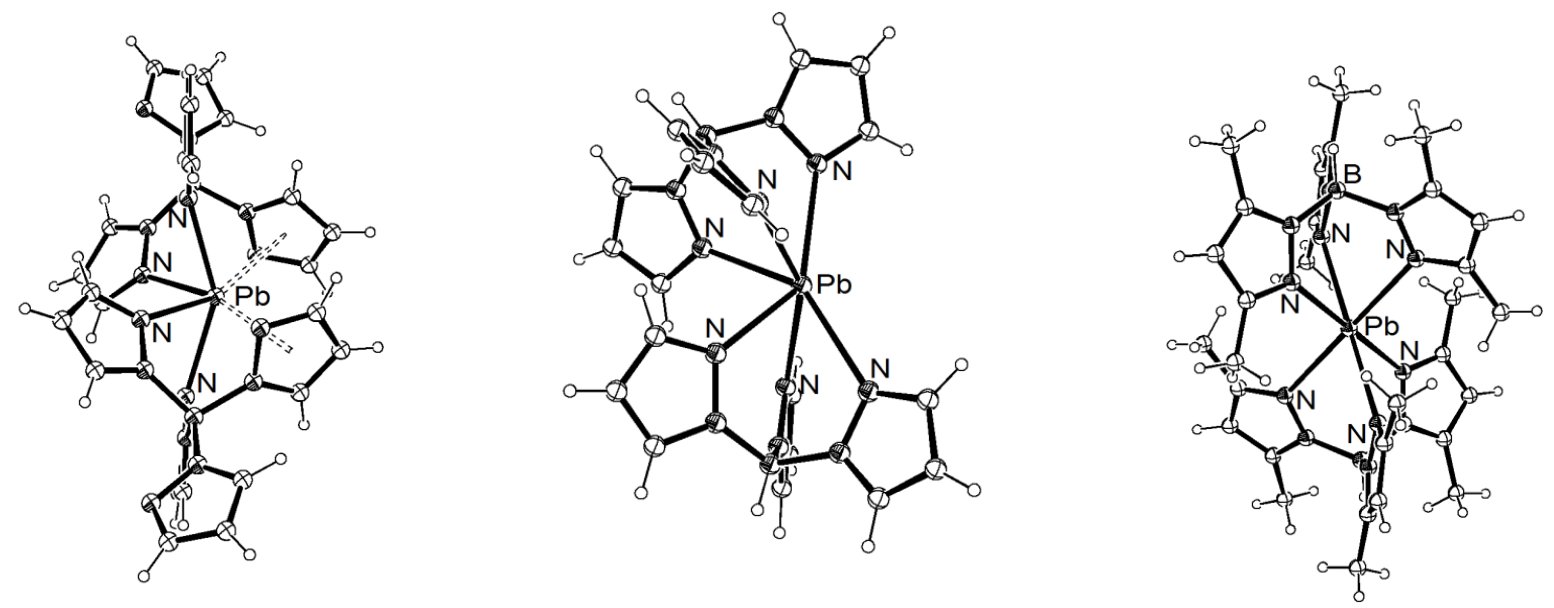

Figure 21. The X-ray crystal structures of $\left[\mathrm{Pb}\left(\mathrm{Tp}^{*}\right)\left(\mathrm{pz}^{*} \mathrm{H}\right)_{3} \mathrm{Cl}\right]$ (left) and $\left[\mathrm{Pb}\left(\mathrm{Tp}^{*}\right)(\mathrm{NCS})\right]$ dimer.
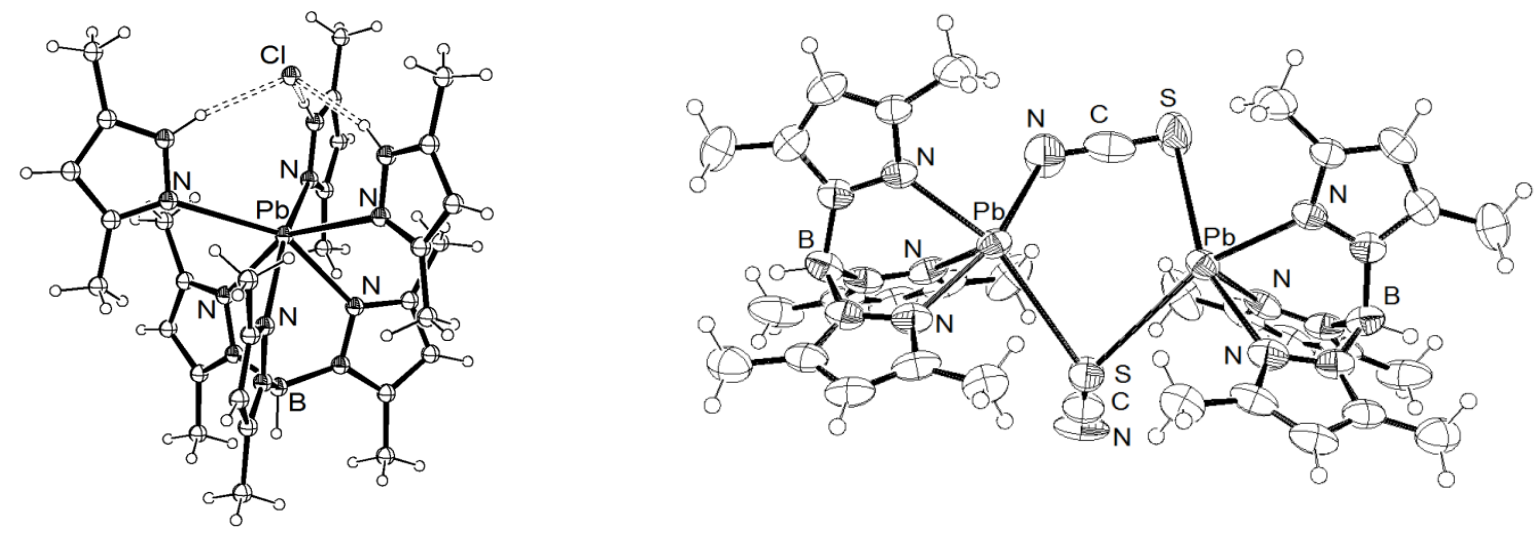

Figure 22. X-ray crystal structures of $\left[\mathrm{Pb}\left\{\operatorname{tris}(1,2,4\right.\right.$-triazolyl)borate $\left.\}\left(\mathrm{NO}_{3}\right)\right]$ (left) showing linkage via the $4-\mathrm{N}$ into $2 \mathrm{D}$ sheets, and monomeric $\left[\mathrm{Pb}\{\operatorname{tris}(1,2,4 \text {-triazolyl }) \text { borate }\}_{2}\left(\mathrm{OH}_{2}\right)_{2}\right]$ (right).
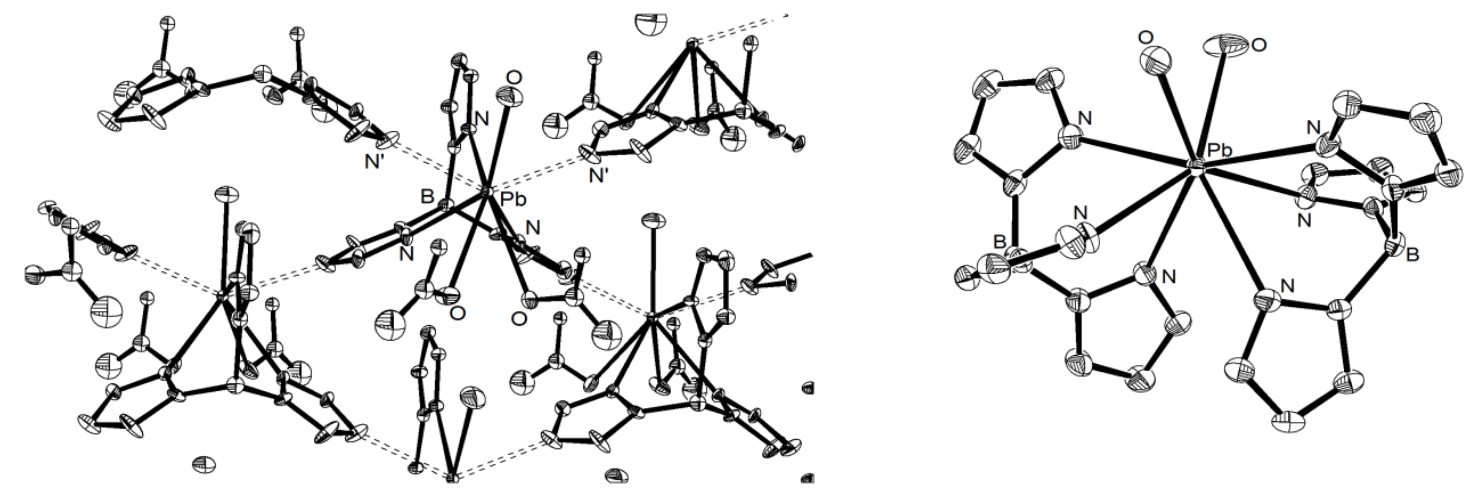
Figure 23. X-ray crystal structure of the 8 -coordinate complex [Bi(Tp)(pzH)Cl].

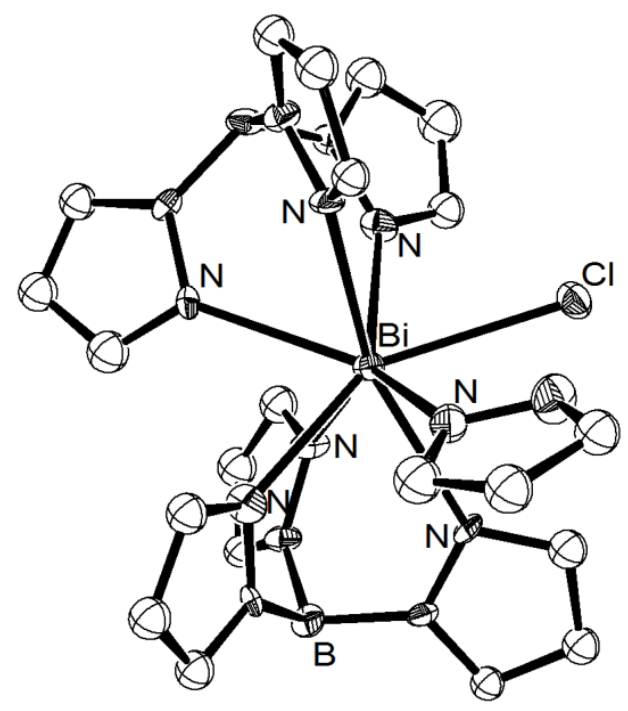

Figure 24. X-ray crystal structures of $\left[\mathrm{Ga}\left(\mathrm{Tm}^{\mathrm{tBu}}\right) \mathrm{I}\right] \mathrm{I}($ left $)$ and $\left[\mathrm{Ga}\left(\kappa^{2}-\mathrm{Tm}^{\mathrm{tBu}}\right)_{2} \mathrm{I}\right]$ (right).
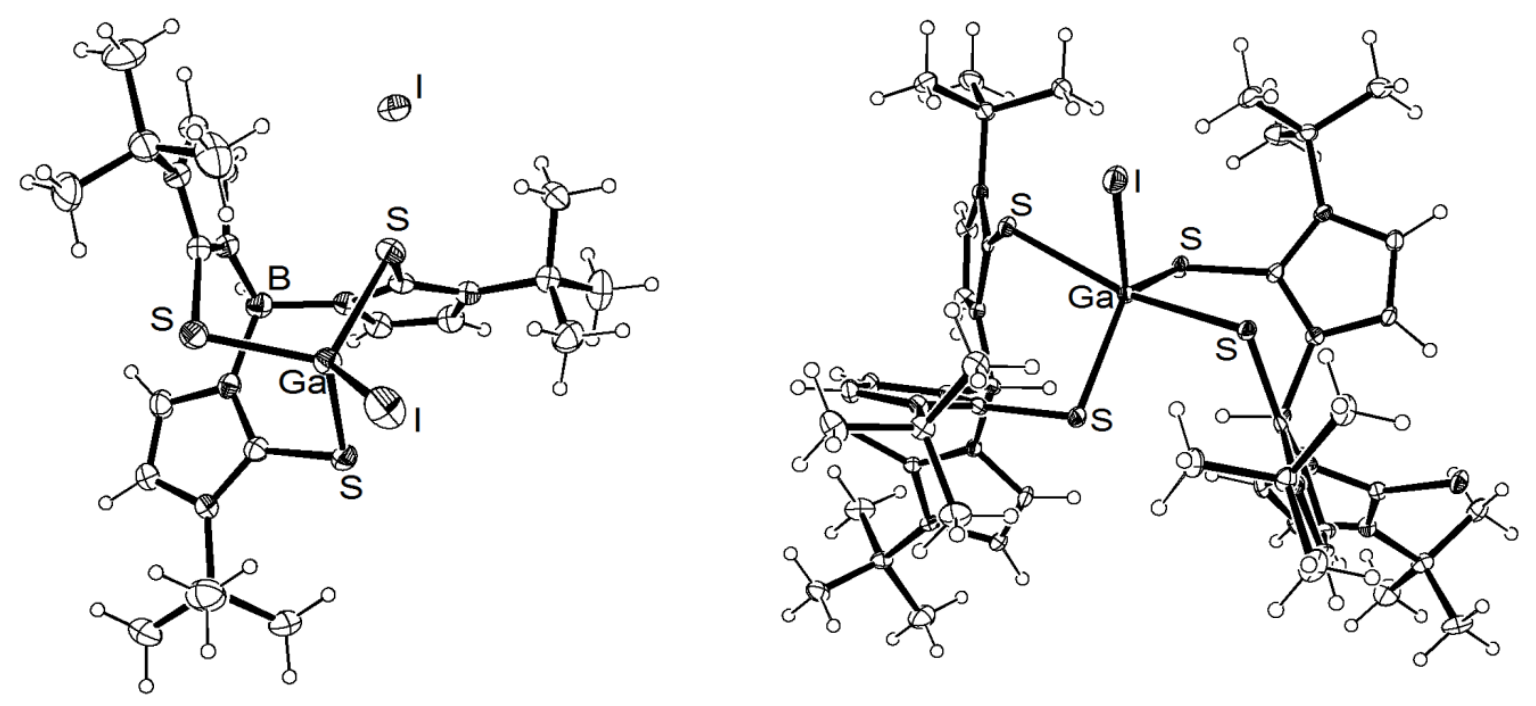
Figure 25. X-ray crystal structures of gallium-gallium bonded complexes $\left[\left(\mathrm{Tm}^{\mathrm{tBu}}\right) \mathrm{Ga}-\mathrm{GaI}_{3}\right]$ (top left); [(Tm $\left.\left.{ }^{\mathrm{tBu}}\right) \mathrm{Ga}-\left(\mathrm{GaI}_{2}\right)-\mathrm{Ga}\left(\mathrm{Tm}^{\mathrm{tBu}}\right)\right] \mathrm{I}$ (top right); $\left[\left(\mathrm{Tm}^{\mathrm{tBu}}\right) \mathrm{Ga}-\mathrm{Ga}\left(\mathrm{Tm}^{\mathrm{tBu}}\right)\right]$ (centre left); $\left[\left(\mathrm{Tm}^{\mathrm{tBu}}\right) \mathrm{GaI}-\left(\mathrm{GaI}_{2}\right)-\mathrm{GaI}_{2}\right]$ (centre right); [(Bm $\left.\left.{ }^{\mathrm{Me}}\right) \mathrm{Ga}(\mathrm{I})-\mathrm{Ga}(\mathrm{I})\left(\mathrm{Bm}^{\mathrm{Me}}\right)\right]$ (bottom left) and $\left[\left(\mathrm{Bm}^{\mathrm{tBu}}\right) \mathrm{Ga}(\mathrm{I})-\mathrm{Ga}(\mathrm{I})\left(\mathrm{Bm}^{\mathrm{tBu}}\right)\right]$ (bottom right).
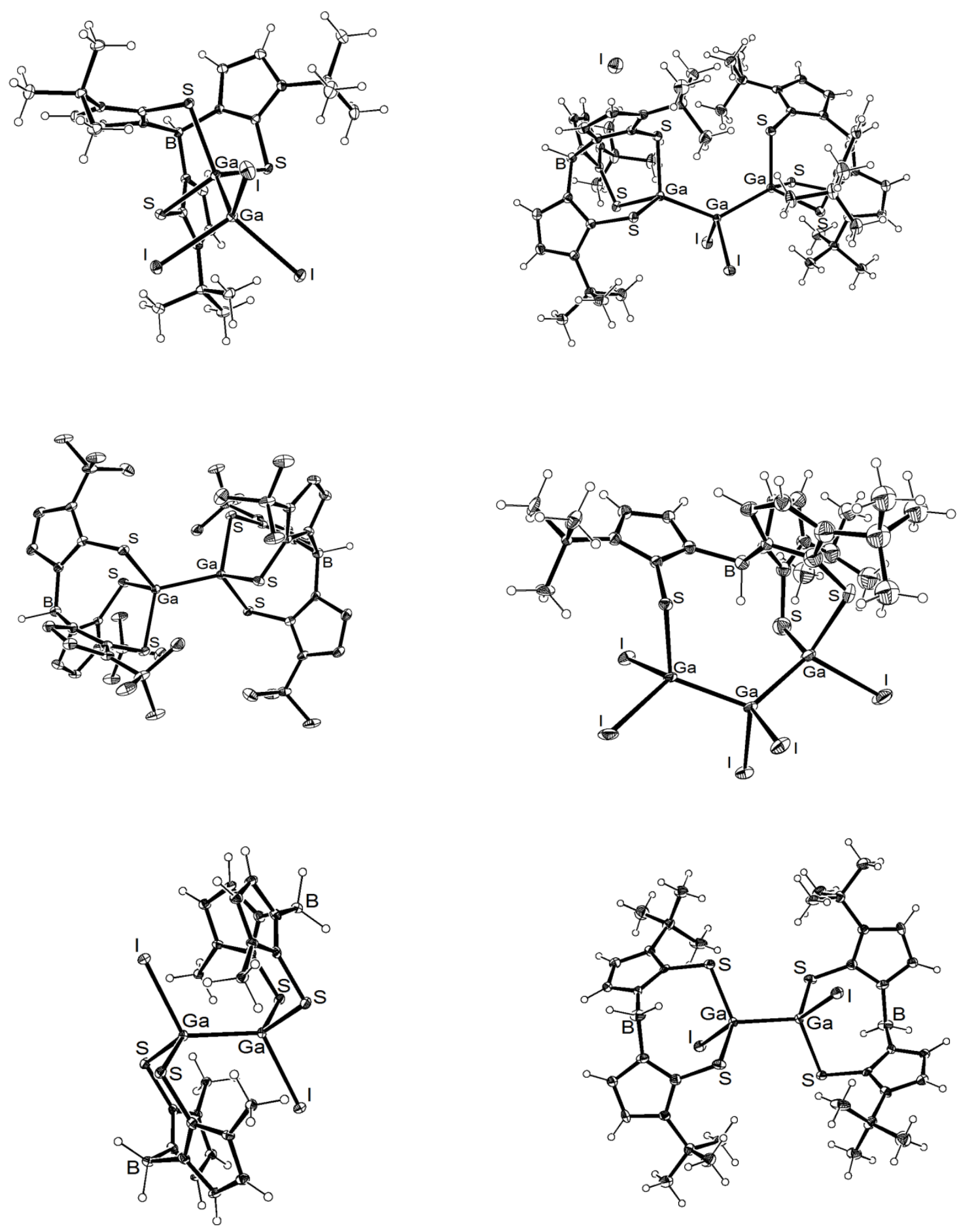
Figure 26. X-ray crystal structures of $\left[\mathrm{Ga}\left(\mathrm{Tm}^{\mathrm{tBu}}\right)\left\{\mathrm{B}\left(\mathrm{C}_{6} \mathrm{~F}_{5}\right)_{3}\right\}\right]$ (left) and $\left[\mathrm{Ga}\left(\mathrm{Tm}^{\mathrm{tBu}}\right) \mathrm{SGaCl}_{3}\right]$ (right).
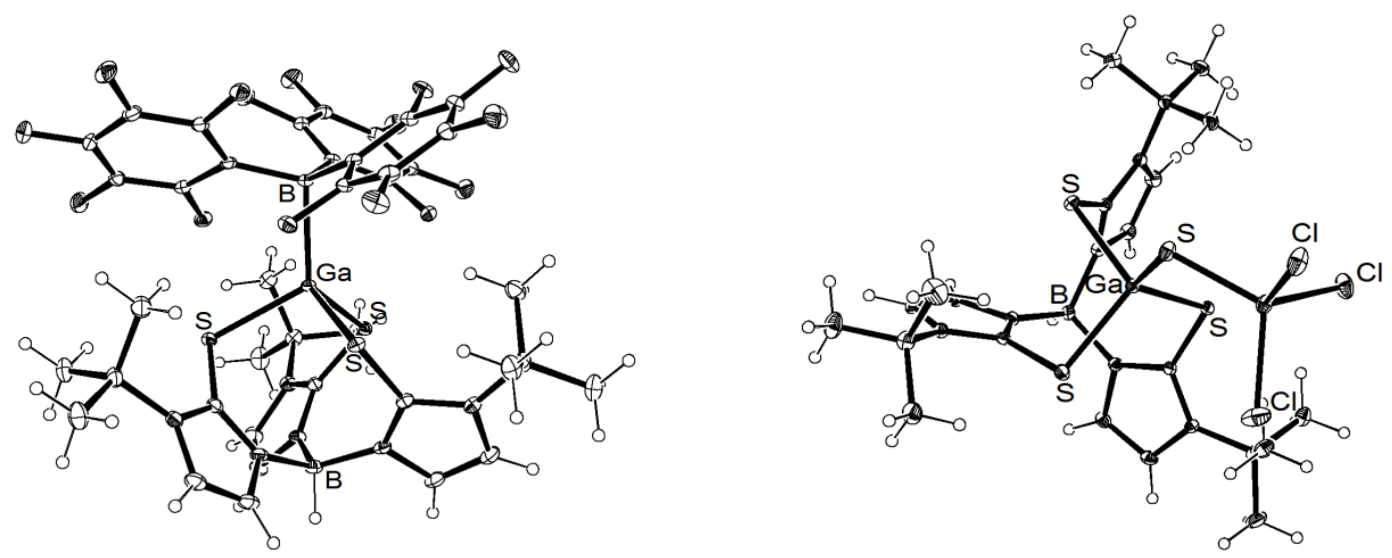

Figure 27. X-ray crystal structure of the $\left[\operatorname{In}\left(\mathrm{Tm}^{\mathrm{Me}}\right)_{2}\right]^{+}$cation showing the compressed ocathedral motif routinely seen with the $\mathrm{Tm}^{\mathrm{R}}$ ligands.

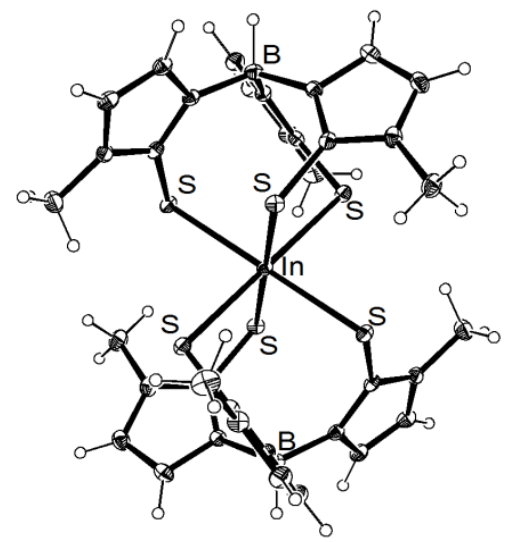

Figure 28. X-ray crystal structure of monomeric $\left[\operatorname{In}\left(\operatorname{Tm}^{\mathrm{tBu}}\right)\right]$.

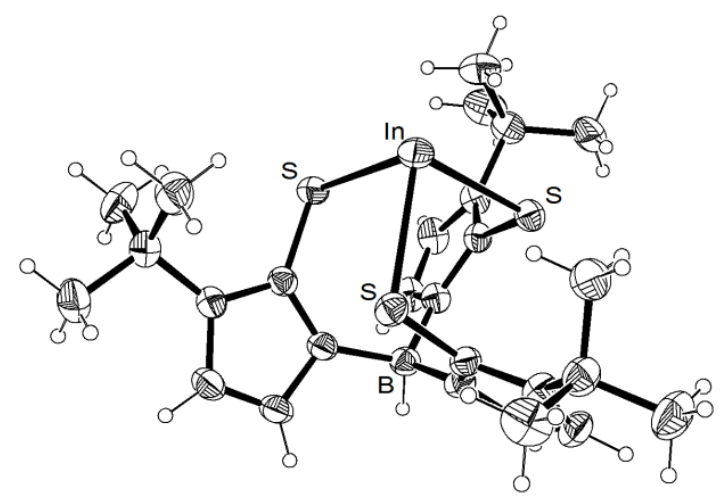


Figure 29. X-ray crystal structures of $\left[\operatorname{In}\left(\kappa^{2}-\mathrm{Tm}^{\mathrm{tBu}}\right)\left(\mathrm{N}_{3}\right)\right]($ left $)$ and $\left[\operatorname{In}\left(\mathrm{Tm}^{\mathrm{tBu}}\right)\left(\mathrm{S}_{4}\right)\right]$ (right).
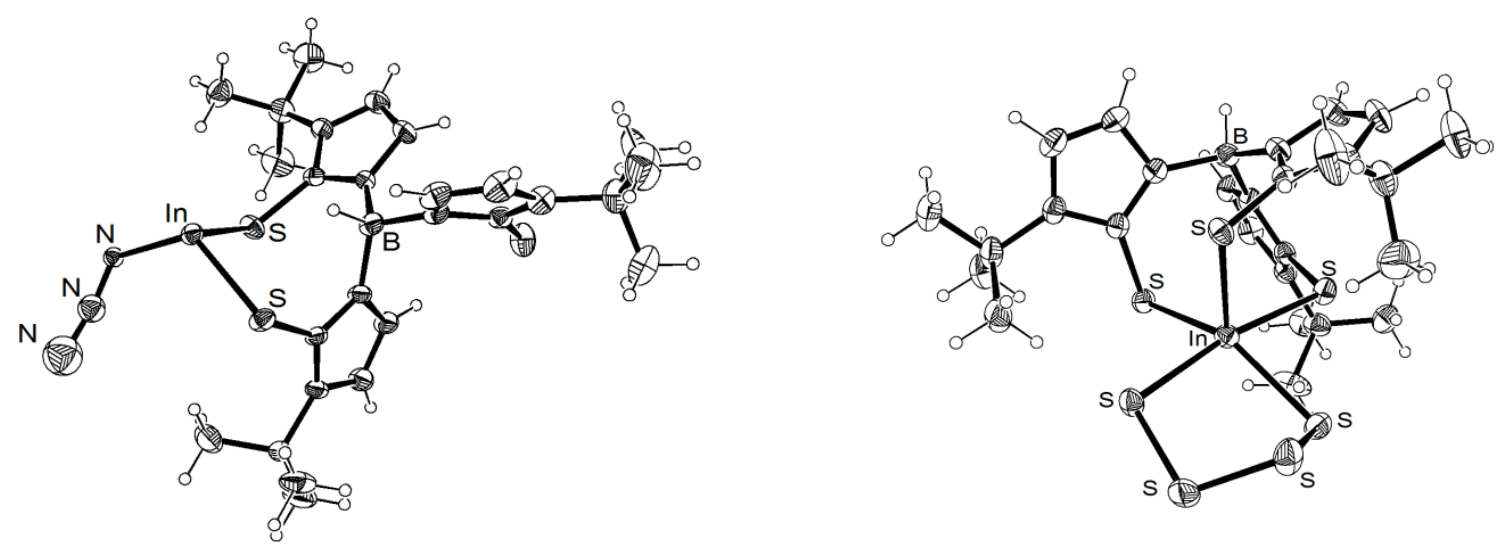

Figure 30. X-ray crystal structures of the $\left[\mathrm{Tl}\left(\mathrm{Tm}^{\mathrm{Ph}}\right)\right]($ left $)$ and $\left[\mathrm{Tl}\left(\mathrm{Bm}^{\mathrm{tBu}}\right)\right]$ (right) dimers.
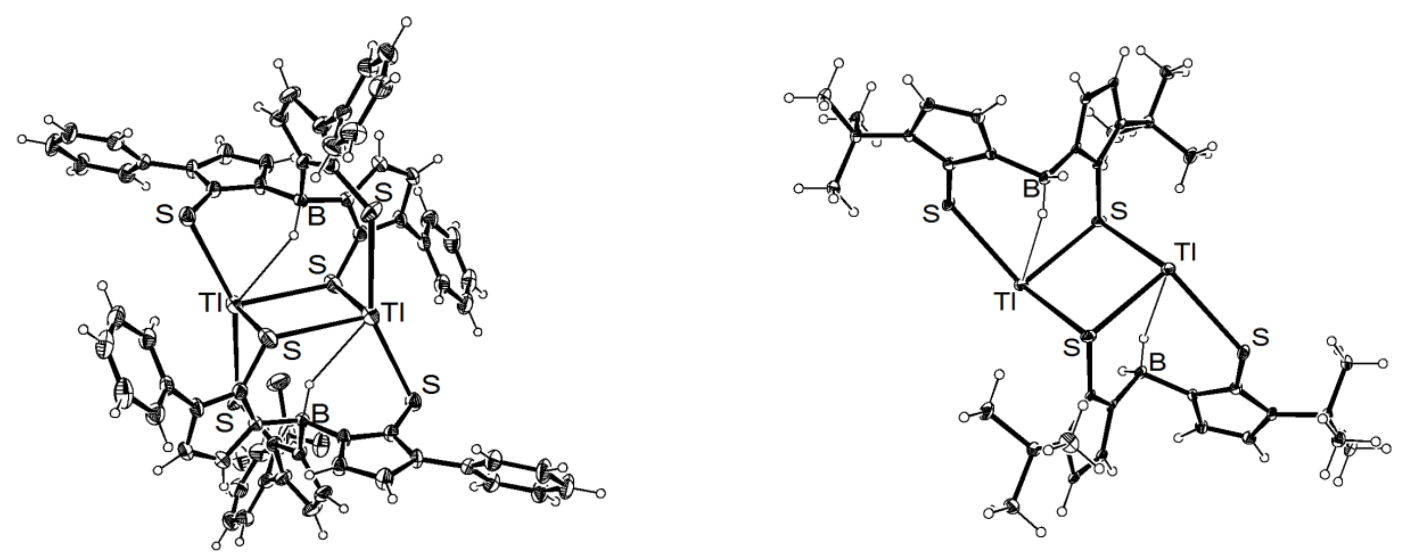

Figure 31. X-ray crystal structure of $\left[\mathrm{Tl}\left(\kappa^{2}-\mathrm{S}, \mathrm{S}-\mathrm{pzBm}^{\mathrm{Me}}\right) \mathrm{Me}_{2}\right]$.showing the exceptionally wide $\mathrm{C}-\mathrm{Tl}-\mathrm{C}$ angle.

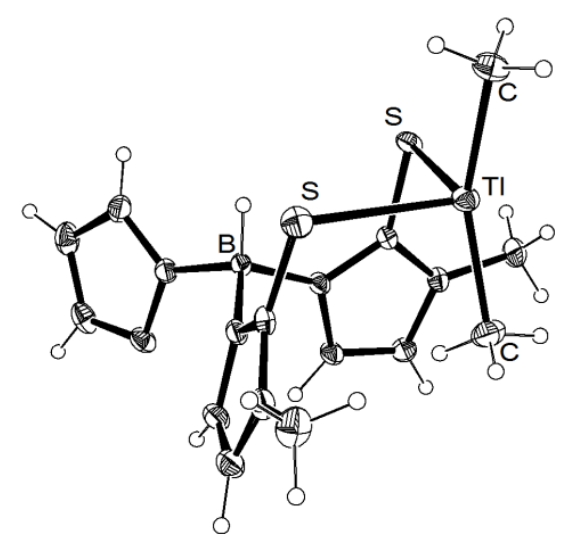


Figure 32. The partial X-ray crystal structure of the thallium complex of the hydrotris(2-thio1,3,4-thiadiazolyl)borate ligand, showing the four-rung $\mathrm{Tl}_{4} \mathrm{~S}_{4}$ ladders linked via the apex of a $\mathrm{Tl}_{2} \mathrm{~S}_{2}$ diamond and the two ligand bonding modes. Ligand 1 (S1, S2, S3) bridges $\mathrm{T} 11$ and T12 bonding in a $\kappa^{1}$ mode to T11 and a $\kappa^{2}$-mode to T12. Ligand 2 (S4, S5, S6) spans five Tl atoms with S4 bridging between T12, T13 and T14; S5 bridges between T15 and T16; and S6 bridges between T12 and T15. The ligand bonds in a $\kappa^{1}$-mode to T13, Tl4 and Tl6 and a $\kappa^{2}$-mode to $\mathrm{T} 12$ and $\mathrm{T} 15$.

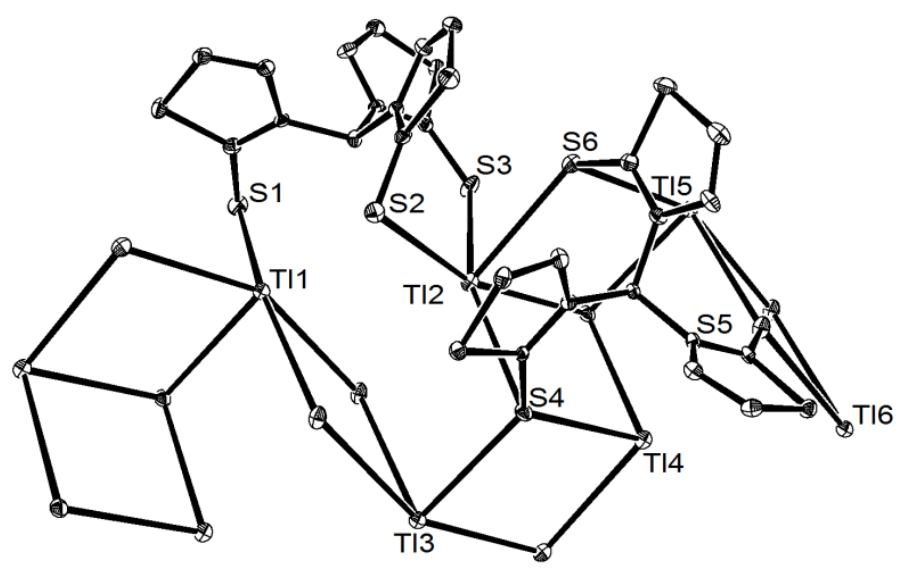

Figure 33. X-ray crystal structure of $\left[\operatorname{Sn}\left(\kappa^{1}-\mathrm{Tm}^{\mathrm{Me}}\right) \mathrm{Cy}_{3}\right]$.

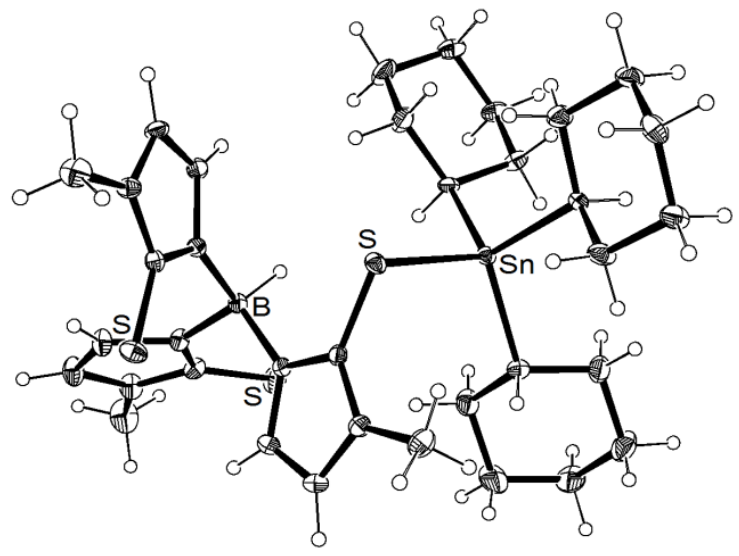


Figure 34. X-ray crystal structure of $\left[\mathrm{Sn}\left(\mathrm{Bm}^{\mathrm{Me}}\right) \mathrm{Me}_{2} \mathrm{Cl}\right]$ showing its association into dimers via chloride bridging.

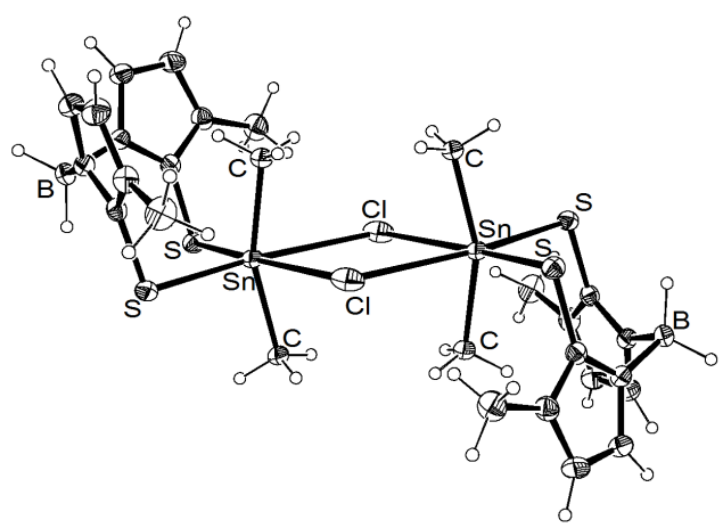

Figure 35. X-ray crystal structures of $\left[\mathrm{Pb}\left(\mathrm{Tm}^{\mathrm{Ph}}\right)\left(\mu^{2}-\mathrm{ClO}_{4}\right)\right]$ (left) showing association into a dimer via the bridging perchlorate ions, and of $\left[\mathrm{Pb}\left(\mathrm{Tm}^{\mathrm{Ph}}\right)\right]\left[\mathrm{Tm}^{\mathrm{Ph}}\right]$ (right) showing one strongly and one weakly bound ligand.
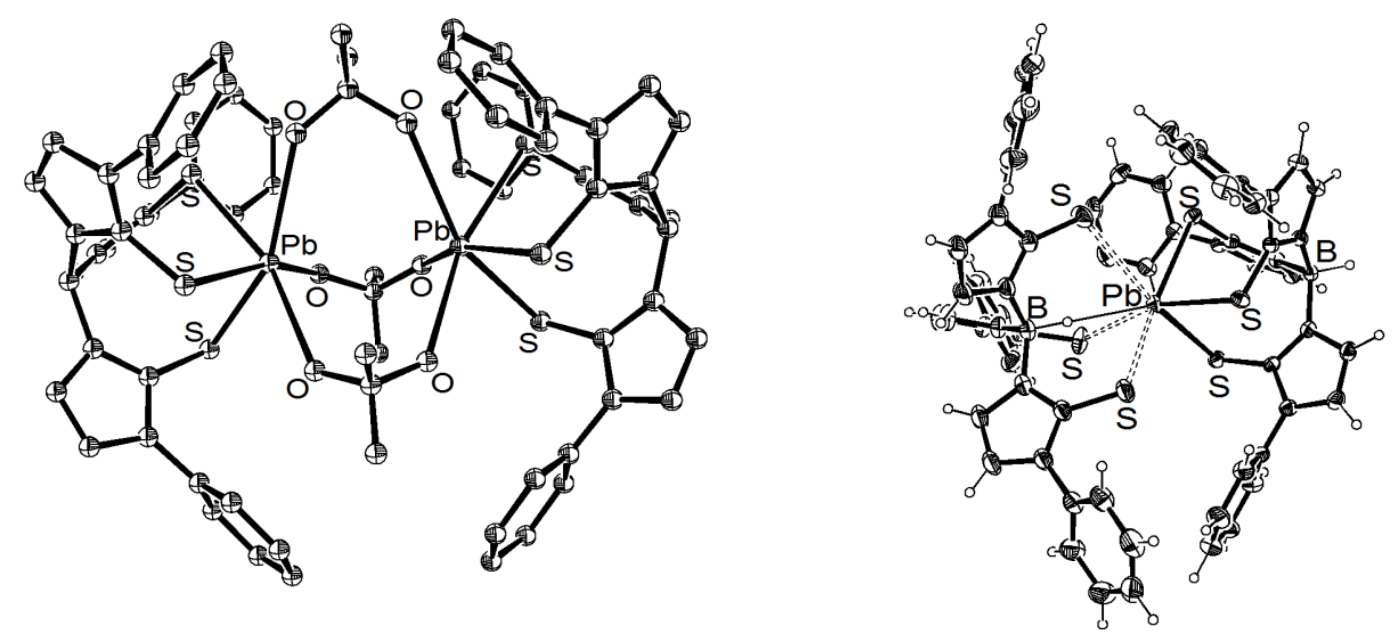

Figure 36 . The X-ray crystal structure of the $I_{2}$ adduct of the cationic heterocycle obtained in the reaction of $\mathrm{PI}_{3}$ with $\left[\mathrm{Na}\left(\mathrm{Tm}^{\mathrm{Ph}}\right)\right]$.

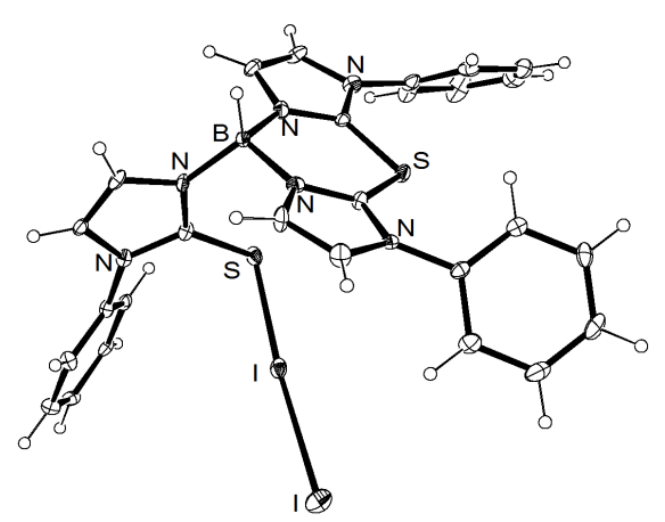


Figure 37. The X-ray crystal structures of $\left[\mathrm{Sb}\left(\kappa^{3}-\mathrm{Tm}^{\mathrm{Me}}\right)\left(\kappa^{1}-\mathrm{Tm}^{\mathrm{Me}}\right) \mathrm{I}\right](1 \mathrm{eft}),\left[\mathrm{Sb}\left(\mathrm{Tm}^{\mathrm{Me}}\right) \mathrm{I}(\mu-\mathrm{I})\right]_{2}$ (right) and $\left[\mathrm{Sb}\left(\kappa^{3}-\mathrm{Tm}^{\mathrm{Me}}\right)\left(\kappa^{2}-\mathrm{Tm}^{\mathrm{Me}}\right)\right]^{+}$(below).
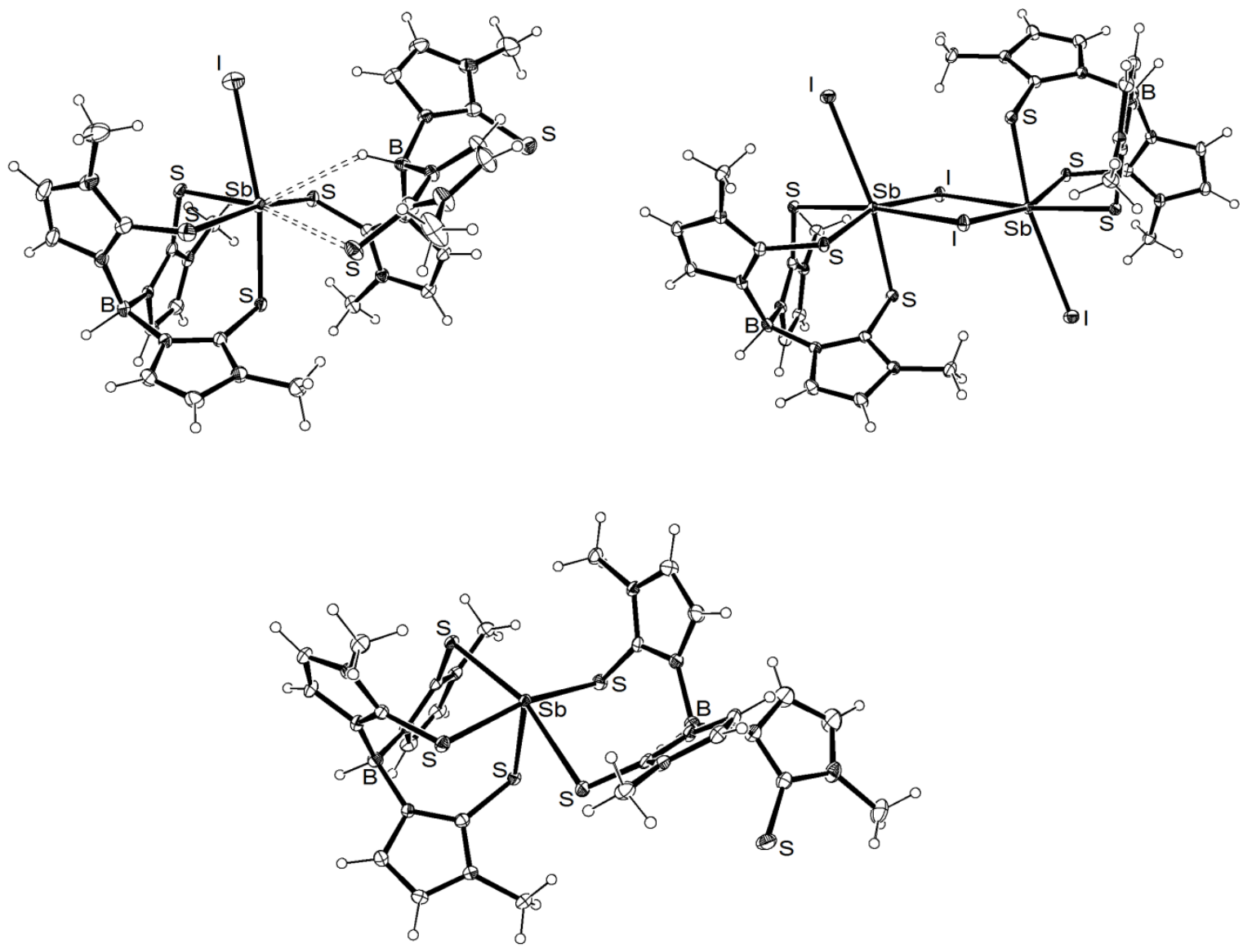

Figure 38. The X-ray crystal structure of $\left[\mathrm{Sb}(\mathrm{Tbz}) \mathrm{I}_{3}\right]^{-}$, showing the cationic polycyclic counterion formed as a degradation product of the reaction.
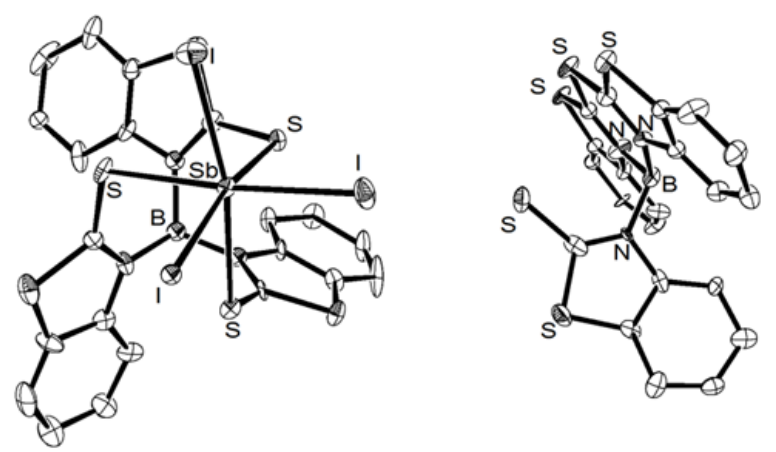
Figure 39. X-ray crystal structures of $\left[\mathrm{Bi}\left(\mathrm{Tm}^{\mathrm{Ph}}\right)\left(\kappa^{2}-\mathrm{NO}_{3}\right)\left(\mu^{2}, \kappa^{2}, \kappa^{1}-\mathrm{NO}_{3}\right)\right]_{2}$ (left) and of $\left[\left(\mathrm{BiMe}_{2}\right)_{3}\left(\mathrm{Tm}^{\mathrm{tBu}}\right)_{2}\right]^{+}$(right).
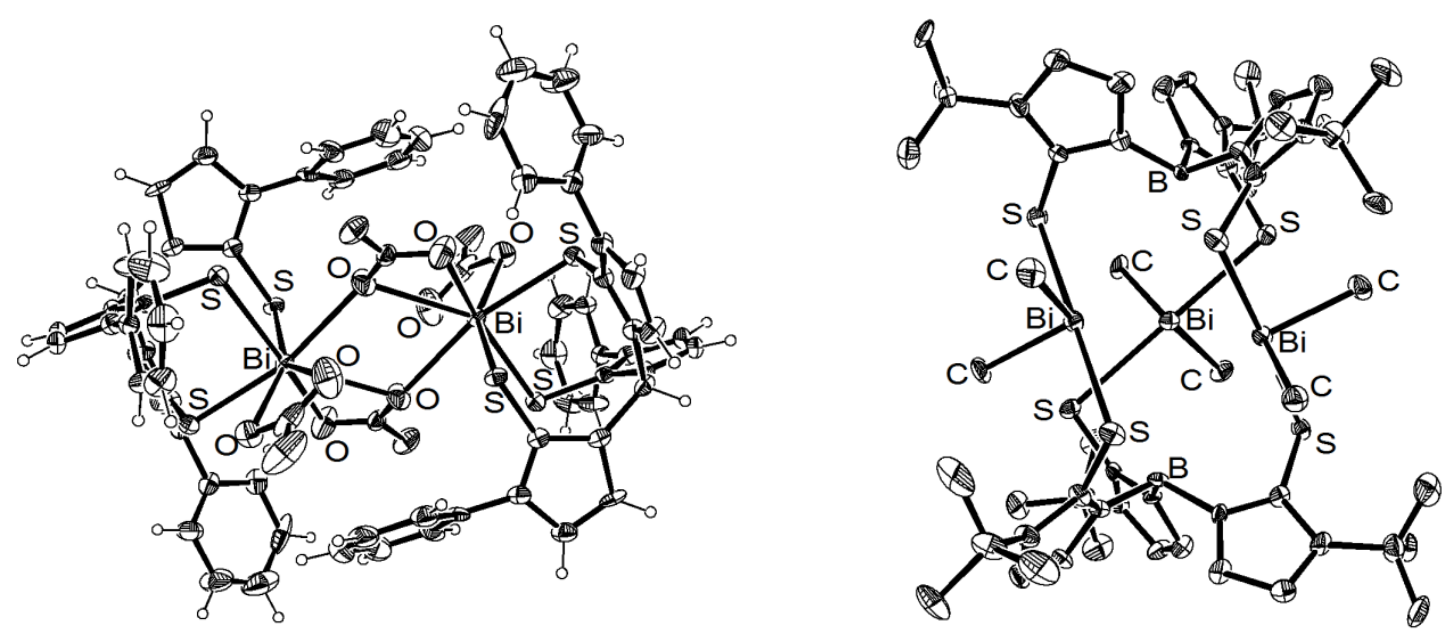

Figure 40. X-ray crystal structure of the bismuth complex of dihydridobis(4-ethyl-3-methyl5-thio-1,2,4-triazoyl)borate.

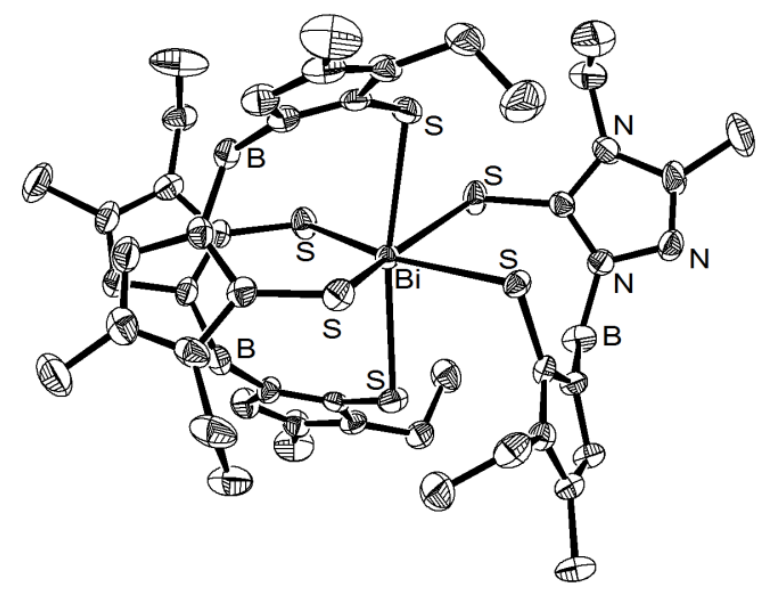

Figure 41. The X-ray crystal structure of $\left[\mathrm{Te}\left(\mathrm{Tm}^{\mathrm{Me}}\right)_{2}\right]$.

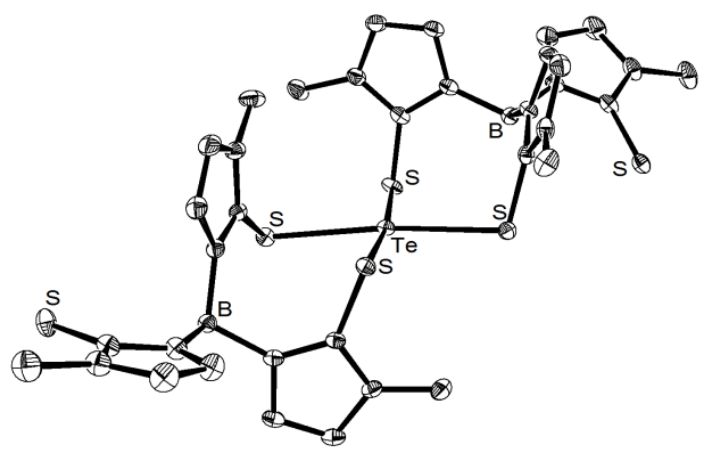

